ARoueología Y SociedAD

№ $30,2015: 425-472$

ISSN: 0254-8062

RECIBIDO: ABRIL DE 2015

ACEPTADO: MAYO DE 2015

\title{
CONVIVIENDO CON LOS ANCESTROS: INVESTIGACIONES ARQUEOLÓGICAS EN RUPAC, HUARAL.
}

Pieter D. VAN Dalen LUnA ${ }^{1}$

UNIVERSIDAD NACIONAL MAYOR DE SAN MARCOS PVANDALEN2@HOTMAIL.COM

HANS G. GRADOS RODRÍGUEZ

UNIVERSIDAD NACIONAL MAYOR DE SAN MARCOS HANS_231@HOTMAIL.COM

FRANCISCO MEDINA SÁNCHEZ ${ }^{3}$

UnIVERSIDAd NACIONAL MAYOR DE SAN MARCOS. FMEDINAS@UNMSM.EDU.PE

Miller Y. MALPARTIDA GAMARRA 4

UNIVERSIDAD NACIONAL MAYOR DE SAN MARCOS YULMILER_253@HOTMAIL.COM

\section{RESUMEN}

Se presenta los resultados de las investigaciones arqueológicas desarrolladas en el complejo arqueológico de Rupac, el sitio de mayor monumentalidad en la región Lima, pero hasta este momento uno de los más desconocidos. Rupac tiene una ocupación continua en los periodos prehispánicos tardíos, definido por el desarrollo de la cultura de los Atavillos en su etapa independiente (Intermedio Tardío) y bajo el dominio del Tawantinsuyu (Horizonte Tardío). Predomina en Rupac la arquitectura tipo Kullpi, edificaciones funerarias a modo de mausoleos con una organización tripartita, en cuyo interior y en los alrededores se realizaban actividades de culto a los ancestros.

Palabras Claves: arqueología, Atavillos, Rupac, Tawantinsuyu, ancestros.

1. Docente auxiliar del departamento académico de Arqueología, Facultad de Ciencias Sociales. Responsable del proyecto especial de investigación UNMSM 2014.

2. Maestría en Gestión del patrimonio cultural, Unidad de Post grado, Facultad de Ciencias Sociales. Miembro y jefe de campo del proyecto especial de investigación UNMSM 2014.

3. Docente asociado del departamento académico de Arqueología, Facultad de Ciencias Sociales. Miembro del proyecto especial de investigación UNMSM 2014.

4. Estudiante VIII ciclo E.A.P. de Arqueología, Facultad de Ciencias Sociales. Miembro del proyecto especial de investigación UNMSM 2014. 


\section{AbSTRACT}

The results of archaeological research carried out in the archaeological complex of Rupac, the most monumental site in the Lima region, but until now one of the most unknown is presented. Rupac has a continuous occupation in the late pre-Hispanic period, defined by the development of culture in its independent Atavillos stage (Late Intermediate) and under the rule of Tawantinsuyu (Late Horizon). Rupac dominates the Kullpi, funeral mausoleums buildings by way of a tripartite organization, within which and around conducting activities in honor of the ancestors type architecture.

KeYwoRDS: archeology, Atavillos, Rupac, Tawantinsuyu, ancestors.

\section{I.- INTRODUCCIÓN}

El artículo presenta los resultados de las investigaciones multidisciplinarias desarrolladas en el complejo arqueológico de Rupac (zona altoandina de la provincia de Huaral), con el auspicio y financiamiento del Rectorado de la Universidad Nacional Mayor de San Marcos, en el marco de los proyectos especiales de investigación 2014. Este proyecto tuvo como objetivo el desarrollo de trabajos de investigación arqueológica, de conservación, así como analizar la importancia de este sitio para la Comunidad Campesina de San Salvador de Pampas, mediante estudios etnográficos y sociológicos, logrando comprender la interacción entre estas poblaciones contemporáneas con su sitio arqueológico, interacciones basadas en la identidad cultural y la actividad turística.

En esta ocasión, por la limitación del espacio, nos centraremos en definir la importancia que tuvo el complejo arqueológico de Rupac en periodos prehispánicos tardíos, es decir, mientras estuvo en uso (800 d.c.- 1550 d.c.), a partir de las evidencias arqueológicas recuperadas durante las excavaciones.

\section{II.- UBICACIÓN}

El complejo arqueológico de Rupac se encuentra ubicado en la ladera superior y la cima del cerro Rupac, ubicado en la margen izquierda del río Chacur, en el contrafuerte que divide las cuencas de los río Chacur y Añasmayo, en los terrenos de la comunidad Campesina de San Salvador de Pampas, distrito de Atavillos Bajo, provincia de Huaral, departamento de Lima; en las coordenadas UTM: N8747415 y E0303078 (WGS-84), a 3500 metros sobre el nivel del mar (Sector C). El medio ambiente es frío, presentando la ladera del cerro abundante vegetación de tipo herbácea, arbustiva y cactácea.

\section{III.- SECTORIZACIÓN}

El complejo arqueológico de Rupac está conformado por cuatro sectores:

Sector A: Se ubica en la misma cima del cerro Rupac, conformado por un conjunto de alrededor de 50 edificios tipo Kullpi, asociados a patios y espacios abiertos. La mayoría de edificaciones se encuentran en buen estado de conservación. En algunos casos presentan chullpas adosadas.

Sector B: Se ubica inmediatamente al suroeste del sector A, conformado por un conjunto de 25 estructuras funerarias tipo chullpas, asociadas a patios cuadrangulares e irregulares.

Sector C: Se trata de un amplio espacio abierto emplazado sobre una abra que divide el cerro Rupac del cerro Shipishcan. En esta área se han identificado cúpulas.

Sector D: Conocido como Marka Kullpi, está emplazado sobre la ladera superior y cima de un gran afloramiento rocoso, con presencia de aproximadamente 20 edificios tipo Kullpi. Estos edificios 


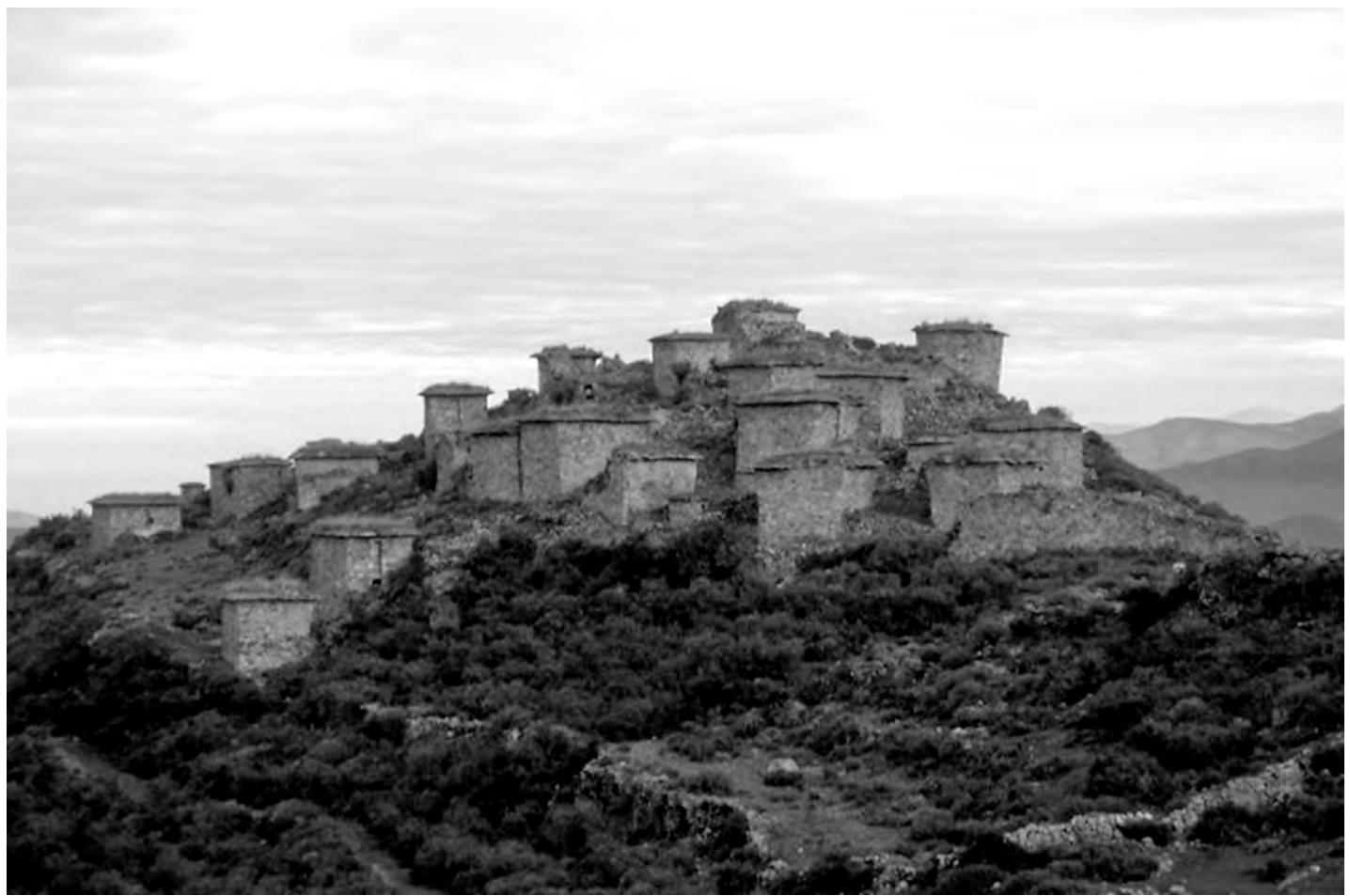

Figura 1: Vista panorámica del sector A del complejo arqueológico de Rupac.

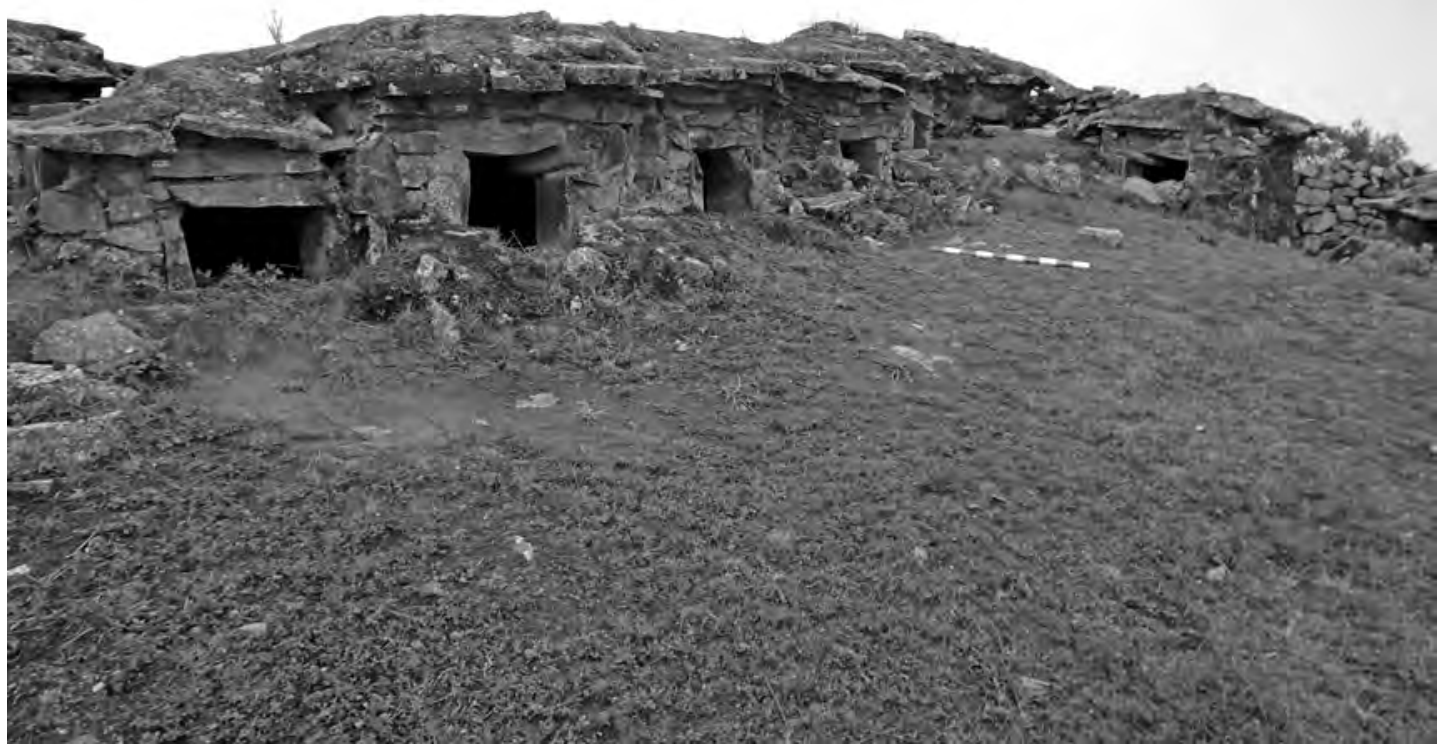

Figura 2: Vista parcial del sector B del complejo arqueológico de Rupac. 


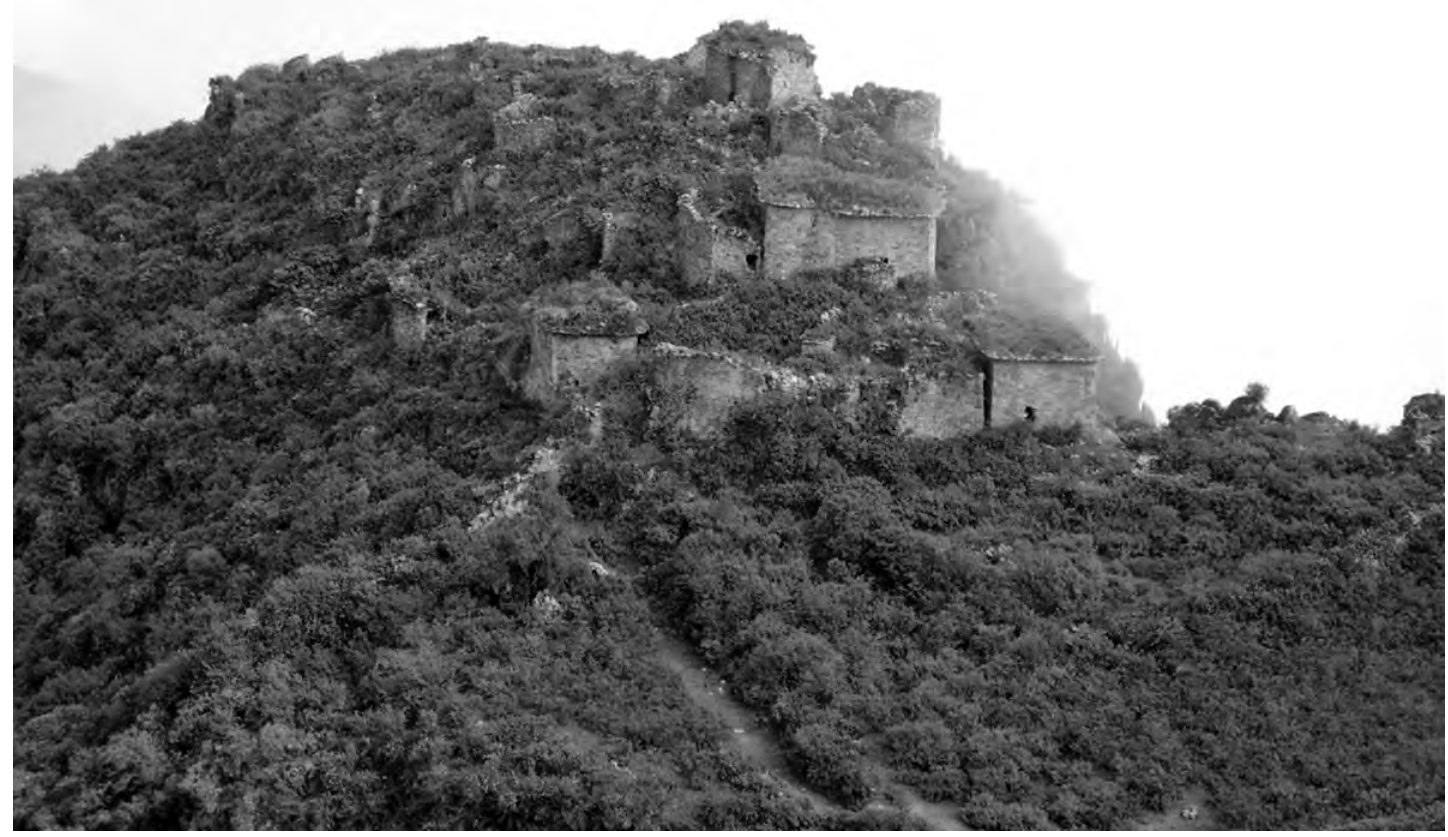

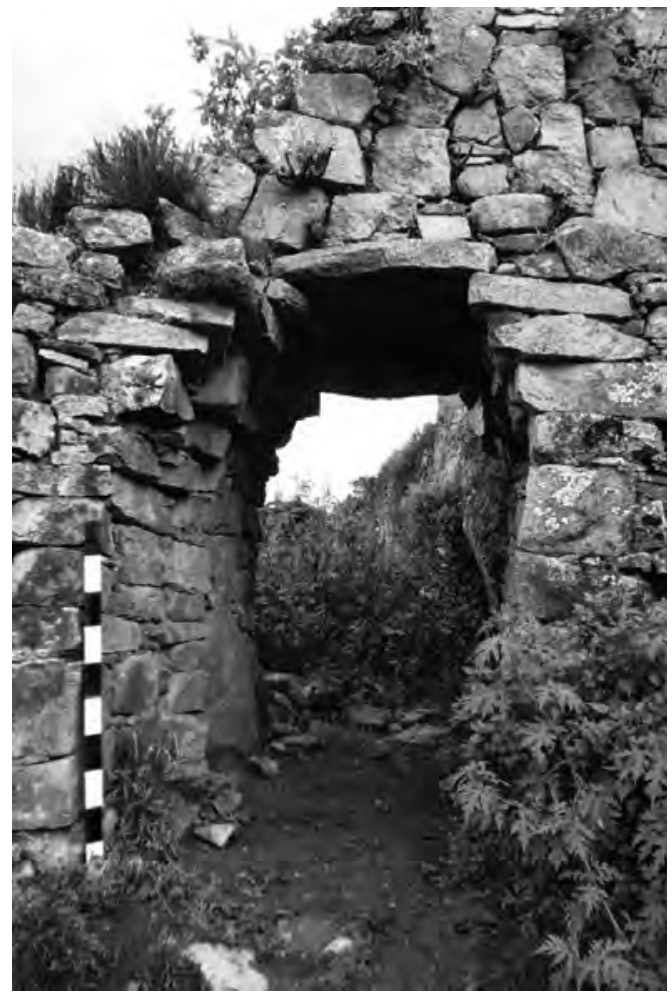

Figura 4: Vista del vano de acceso ubicado al oeste de la muralla sur.
Figura 3: Vista panorámica de la parte baja del sector Marca Kullpi (sector D).

se agrupan formando espacios abiertos internos de forma cuadrangular. Este sector se diferencia de los otros por cuanto se encuentra amurallado, presentando en el lado oeste hasta dos sistemas de murallas, en el lado sur la muralla llega a tener hasta 6 metros de altura, mientras que en su lado oeste presenta un vano de acceso de forma rectangular de $2 \mathrm{~m}$ de alto, $1.80 \mathrm{~m}$ de ancho y $1.30 \mathrm{~m}$ de grosor, estando el vano orientado al suroeste. En el extremo oriental del sector, la muralla tiene dos características: en las zonas de poca pendiente la muralla fue levantada cimentándola al suelo rocoso; en cambio en otras zonas de acantilados la muralla se emplaza en las oquedades rocosas sobre el acantilado rocoso, cumpliendo la función tanto como muralla (visto desde abajo) y como muro de contención (visto desde arriba). Existen algunas zonas donde los acantilados tienen más de $80^{\circ}$ de pendiente, ya no fue necesario la construcción del muro perimétrico, por lo inaccesible del terreno. 


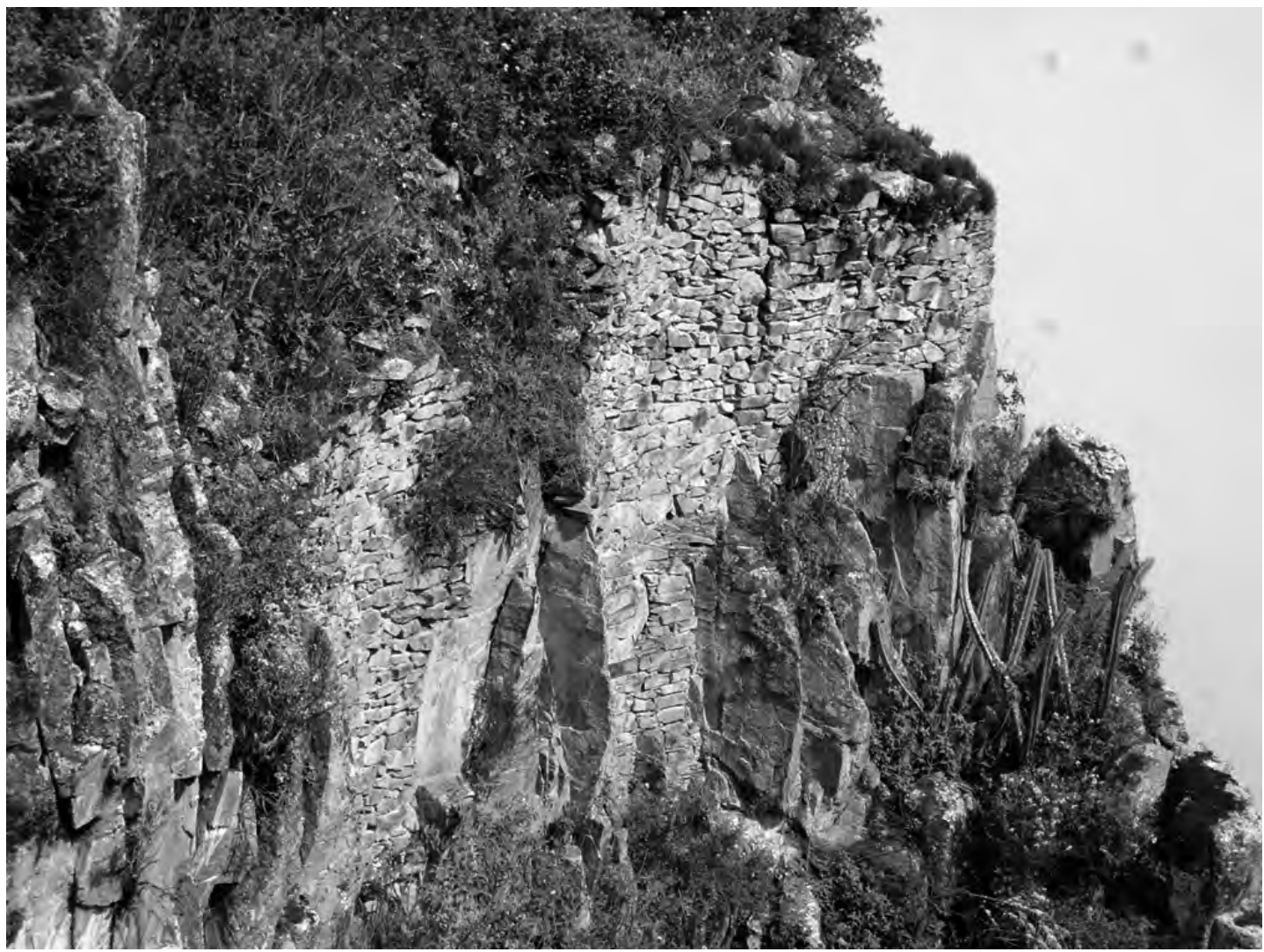

Figura 5: Vista de la muralla en el extremo este del sector D, donde se aprecia la doble característica mencionada.

\section{IV.- El culto a los ANCESTROS EN LOS ANDES PREHISPÁNicos}

\section{Y EN LA CUENCA ALTA DEL RÍO CHANCAY-HuARAL}

Un ancestro es el antepasado directo por parentesco que puede ser el progenitor inmediato (padre o madre), o recursivamente, el progenitor de cada uno de ellos (abuelos, bisabuelos, tatarabuelos, y así sucesivamente). El término igualmente suele ser usado para referirse a un grupo de personas relacionadas a un antepasado directo del cual desciende o cree descender un individuo o un grupo social (familia, clan, tribu, etnia, pueblo, etc.). En los Andes, desde periodos muy tempranos en que la sociedad se complejizó, se configuró el culto a los ancestros de cada ayllu, los cuales en periodos tardíos y en referencia de las crónicas eran conocidos como "mallquis". Existía una relación ideológica directa entre los miembros de un ayllu y sus mallquis, a quienes mantenían presente tanto física como espiritualmente. Así, para las sociedades andinas prehispánicas (en algunas hasta la actualidad) la muerte no significaba el fin definitivo sino una transición a un sistema en el cual cumplían una función protectora de la sociedad a la cual pertenecieron o fundaron, siendo fundamentales en la escala social a pesar de estar muertos. Durante las campañas coloniales de extirpación de idolatrías, muchos curas españoles destruyeron adoratorios en cuevas, pueblos andinos, rocas, lagunas, donde los andinos adoraban las tumbas de sus mallquis, machus, aukis, ñaupas y gentiles. Estos curas describían en sus documentos eclesiásticos el proceso de extirpación o destrucción de estos mallquis a fin de con- 
vertir a la población andina de manera definitiva a la religión católica. En la actualidad existen numerosos estudios sobre estos procesos (Arriaga 1968, Estenssoro 2003, Galdames y Marsilli 2012, Gareis 2007, Huertas 1981, 2008, y Taylor 1987). Dentro de la concepción andina estos mallquis o personajes fundacionales emergieron de una paqarina o lugar sagrado a fin de fundar los pueblos donde vivieron sus hijos y descendientes, siendo luego estos mallquis en muchos casos enterrados en las mismas paqarinas a modo de machayes, generándose una interacción entre creacionismo y muerte (Doyle; 1988: 145). El cuidar el cuerpo de los muertos fue una práctica muy común entre las sociedades andinas, incluso la de los enemigos derrotados en batalla, a fin de llevarlos a los cementerios o cuevas donde eran depositados para ser objeto de culto durante cada año, para lo cual incluso había la necesidad de construir grandes y complejas estructuras funerarias, como lo hicieron los Recuay o los Tiwanaku.

En el Tawantinsuyu, a pesar que no era una práctica propia del valle del Cuzco, el culto y cuidado del cuerpo de los Incas muertos se daba en sus propias panacas, tomando la tarea de demostrar el poder vigente en la estructura política del Estado de este gobernante (Hernández 2012: 125). Van de Guchte (1990: 331-333) identifica varias categorías funcionales en las rocas esculpidas del Tawantinsuyu con poder religioso y de culto: 1.- Como símbolos de conmemoración, como marcadores de orígenes ancestrales en lugares de eventos cosmogónicos o como marcadores territoriales (huanca, pururauca y sayhua); 2.- Se establecen como instrumentos de mediación y de comunicación entre los mortales y lo sobrenatural, en forma de altares para ofrendas y libaciones (chanca, tiana y ushnu); 3.- Indican diferentes modos de identidad o jerarquía (huaca), incluyendo el culto a los ancestros y a la muerte.

Por otra parte, el culto a los mallquis o ancestros no solo se limita a la estructura funeraria donde es depositado, sino que abarca también el área funeraria y el paisaje circundante, por lo general asociado e interrelacionado con un apu o cerro tutelar. El culto a los antepasados se realizaba con mucho amor y reverencia, pero también con mucho temor a las represalias si estos no quedaban satisfechos de las ofrendas (Ibarra 2006: 87). Luego de la invasión hispana y los cambios socioculturales contemporáneos, parte de este sistema de culto se mantiene aunque con variaciones significativas, como en la celebración del día de los muertos cada $1^{\circ}$ de noviembre en todos los Andes, donde se configura la idea del regreso de las almas de los ancestros, para lo cual hay que ofrecerles banquetes, bandas de música, bebidas, visitas a los cementerios y otros; esto con el fin que los antepasados protejan y den bienestar al grupo de descendencia (Celestino 1997, Lazo 2012).

En la cuenca alta del río Chancay-Huaral, el culto a los antepasados y a las divinidades era una actividad muy arraigada entre su población, mediante el desarrollo de pomposas festividades que podían tener varios días de duración y donde la coca cumplía una función importante como producto regulador del culto (van Dalen 2007: 136-137).

En el caso de Rupac, la ubicación estratégica sobre la cima del cerro del mismo nombre, permite ser observado desde varios puntos de la cuenca alta del río Chancay, al igual como desde este lugar se visualiza el fondo del valle medio (zona de Añasmayo, Huataya y Vilca), se visualizan los cerros bajos de la costa y se visualizan otros asentamientos arqueológicos de vivienda, control y funerarios de la cultura Atavillos, así como el cerro Mango, uno de los apus de los Atavillos. El Cerro Mango Cápac, denominado en periodos prehispánicos como Cerro Chuquimango (Suárez 2014: 28-29, Duviols 1967: 30), está conformado por tres sectores que a su vez se componen de plazas, recintos circulares y rectangulares, relacionados con el culto a la divinidad, con una muralla perimétrica que encierra el sitio por todos sus lados (Cáceda 2014). 


\section{V.- Resultado de las excavaciones}

A continuación presentamos los resultados de las excavaciones realizadas en algunas de las 14 unidades planteadas en el sector A del complejo arqueológico de Rupac.

\section{1.- UNIDAD 1:}

Se encuentra ubicada en la parte más alta del sector A, en la zona central, al norte de la unidad 7 y al oeste de la unidad 13. Esta unidad abarca tres recintos colindantes (adosados), cuya área de excavación comprende el interior de las edificaciones, de 10m de largo en dirección norte-sur y $2 \mathrm{~m}$ de ancho en dirección este-oeste. El punto datum (WGS-84 para todas las unidades) se ubica en la esquina nor-este de la unidad: $8747452 \mathrm{~N}$ y $0303029 \mathrm{E}$, a una altitud de 3534 m.s.n.m. La profundidad final de las excavaciones alcanzó $1.82 \mathrm{~m}$ aprox. Los tres recintos adosados son de forma cuadrangular, con las esquinas ovaladas en la parte interna. Estas edificaciones se emplazan sobre un terreno rocoso utilizando para las construcciones materiales de la misma zona (piedras canteadas), las esquinas de la parte posterior de estos tres edificios fueron elevadas con piedras de forma rectangular y cuadrangular tipo sillares, el paramento del muro está compuesto también con pachillas, o pequeñas cuñas y piedras de $0.70 \mathrm{~m}$ de largo, $0.60 \mathrm{~m}$ de ancho y una altura de $0.50 \mathrm{~m}$ aproximadamente. Para unir estas piedras se utilizó argamasa de arcilla de color blanquecina, traídas de canteras muy próximas al sitio arqueológico. Los muros tienen un grosor de $0.45 \mathrm{~m}$ a $0.55 \mathrm{~m}$. Estos tres recintos son contemporáneos. Los vanos de acceso de estos tres recintos presentan pequeños dinteles, al interior de la cámara está dividido

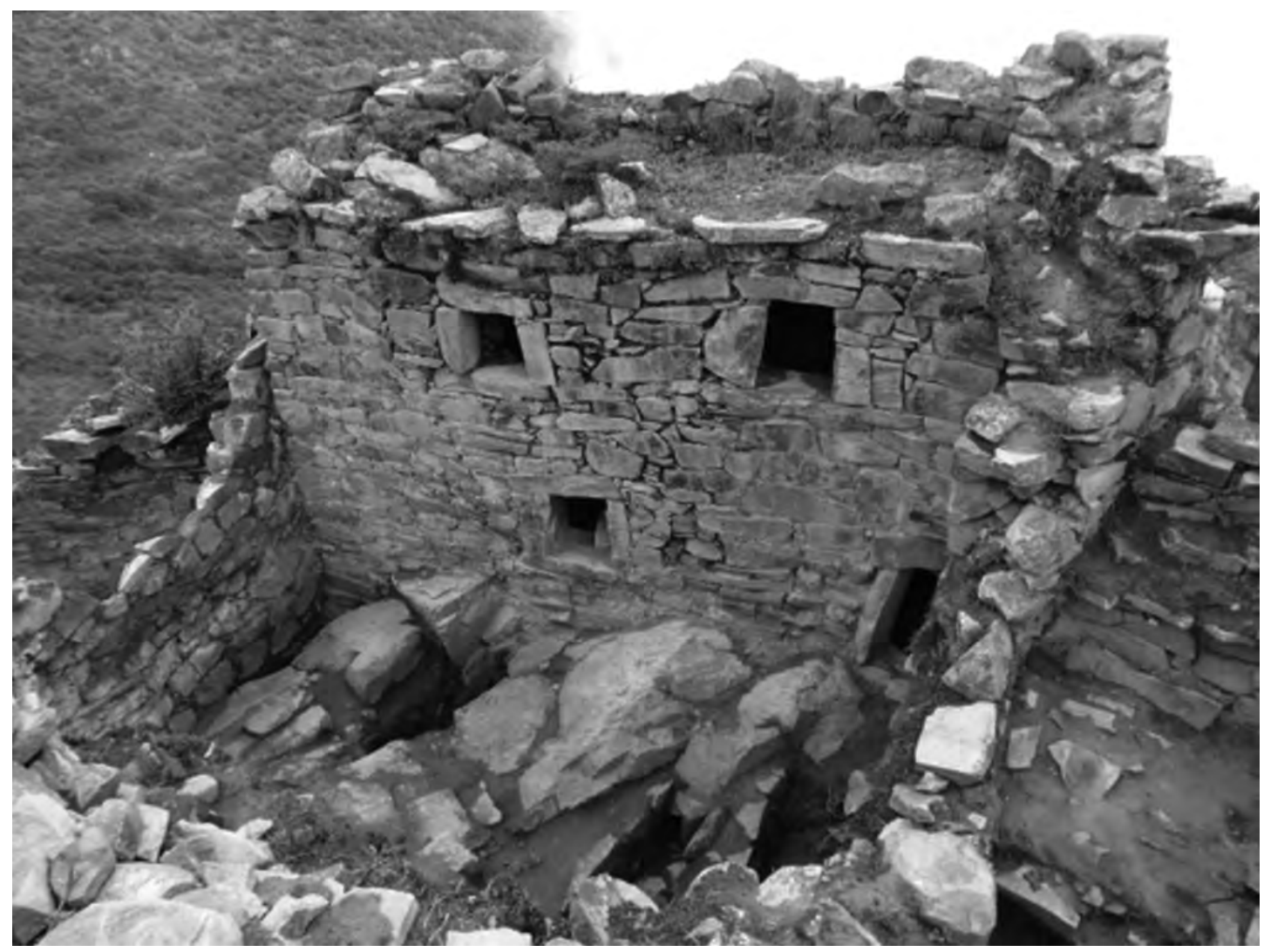

Figura 6: Edificio de la unidad 1. 
en dos niveles con grandes lajas de piedra como la cubierta, en la cámara se encuentra evidencia de las cornisas o voladizos que son parte del techo, que probablemente haya sido de forma abovedado. Los vanos por recintos están compuestos en el siguiente orden, el primer recinto tiene tres vanos, el primero está orientado hacia el norte, el segundo está orientado hacia el oeste y que comparte con el recinto $\mathrm{N}^{\circ} 2$; el tercero se encuentra orientado hacia el sur. El segundo recinto se encuentra compuesto por un vano que comparte con el recinto $\mathrm{N}^{\circ} 2$. Dentro de este recinto se encuentra la cámara de dos niveles, hallándose cuatro vanos: el primer vano del primer nivel mide $0.70 \mathrm{~m}$ de altura y $0.50 \mathrm{~m}$ de ancho, el segundo vano del primer nivel; así como los otro dos vanos que son del segundo nivel miden $0.50 \mathrm{~m}$ altura por $0.50 \mathrm{~m}$ de ancho.

El recinto $\mathrm{N}^{\circ} 1$, se trata de una unidad funeraria de planta cuadrangular, el material constructivo es en base a piedras canteadas, pachillas y argamasa de arcilla. Sus dimensiones son: largo de $4.20 \mathrm{~m}$, ancho $3.30 \mathrm{~m}$, altura $3.00 \mathrm{~m}$ y el vano de $0.50 \mathrm{~m}$.

El área de la unidad se encuentra muy afectada, producto del abandono por casi de 500 años y por los constantes huaqueos e incursiones de los turistas; hallándose en un estado de conservación deplorable. Al emplazar la unidad nos encontramos con la abundante vegetación por la característica de la región y del clima de la estación. Una vez limpiada la vegetación se procedió a la cuadriculación, encontrándonos con un derrumbe denominado capa $\mathrm{S}$, este derrumbe es producto del desplome de los muros que conforman el edificio. Una vez retiradas las piedras del derrumbe se identificó la capa A (apisonado), paralelamente en los tres recintos; esta capa estaba compuesta por arcilla e inclusiones de raíces y piedras. Es en esta capa donde se identificó 20 hallazgos, como parte del relleno del apisonado: 5 piruros de cerámica, 1 piruro de osamenta animal, 1 preforma de piruro de cerámica, 1 preforma de piruro de piedra, 5 instrumentos musicales de viento elaborados en osamenta animal, 2 percutores, 1 chancador, 2 pulidores de piedra, 1 núcleo de piedra y un 1 dije de plata. Posterior a esta capa se identificó la capa B, compuesta por la roca geológica. Fue en esta roca donde se prepararon matrices para desechar basura arqueológica (alimentos, semillas, fragmentos de cerámica, etc.), crear cistas para entierro (CF-1), además de identificar 7 hallazgos en el relleno de las matrices o cistas. Como parte del relleno también se identificó quemas y ceniza, lo cual preservó el material orgánico, permitiéndonos recuperar valiosa información. Los hallazgos identificados fueron: 4 piruros, 2 chancadores, 2 pulidores, 1 mortero, 1 percutor, 1 punta de proyectil y 1 dije de piedra. Por otro lado se identificó una cista, la cual contenía al contexto funerario $\mathrm{N}^{\circ} 1$.
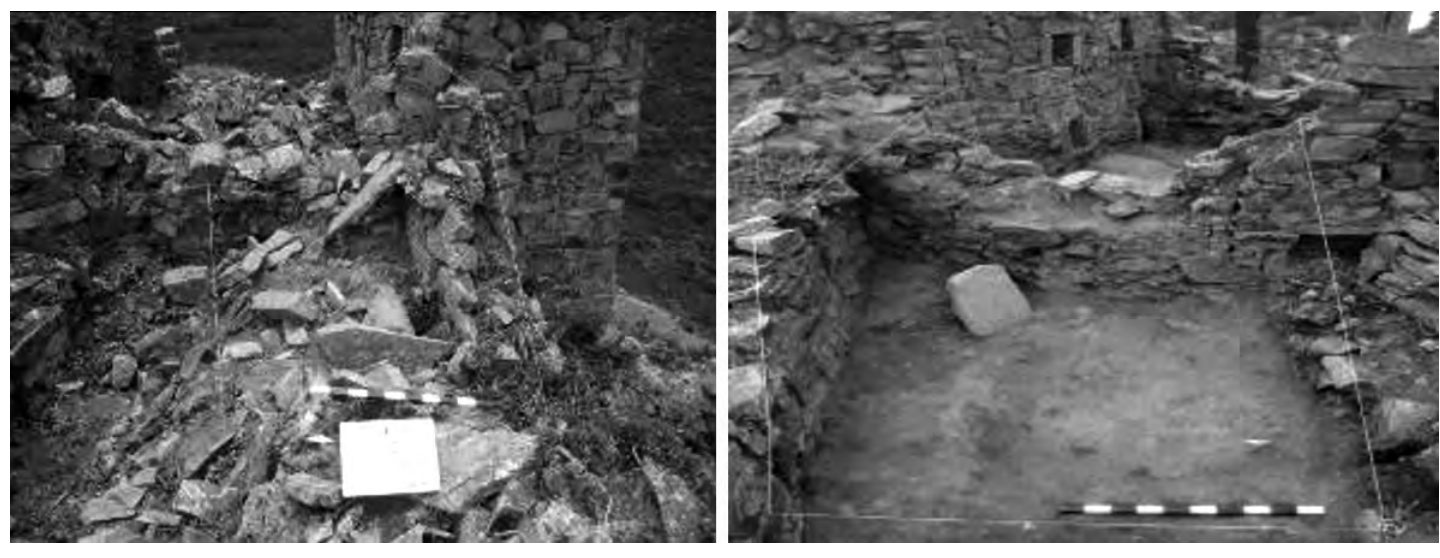

Figuras 7 y 8: A la izquierda foto de la capa superficial. A la derecha foto de la capa A. 

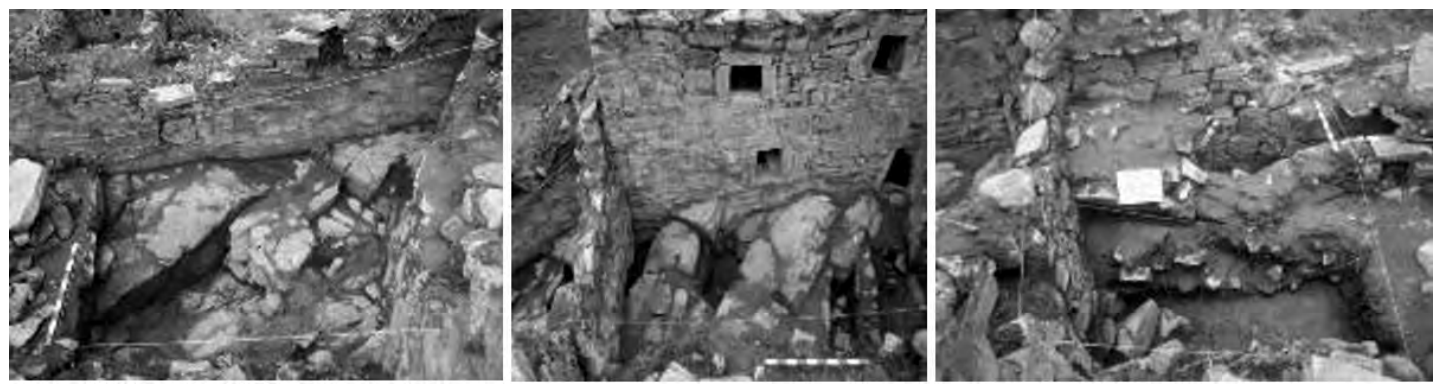

Figuras 9, 10 y 11: Fotografía panorámica de la capa B. se aprecia los tres recintos excavados.

Contexto Funerario $\mathrm{N}^{\circ} 1$ : El contexto funerario 1 está ubicado dentro del recinto $\mathrm{N}^{\circ} 2$ exactamente en la parte sur central, sobre la base de la edificación, dentro de una matriz elaborada sobre la roca madre, compuestos de cenizas y abundante material cultural (básicamente fragmentos de cerámica, osamenta de animales y material orgánico).

Estructura Funeraria: Se trata de una matriz de forma irregular, cuyo largo máximo en dirección $\mathrm{N}-\mathrm{S}$ es de $2.20 \mathrm{~m}$ y un ancho E-W de $1 \mathrm{~m}$, con una profundidad de $0.70 \mathrm{~m}$. Dicha matriz presentaba un relleno en la parte superior conformada por material cultural; formada por tierra semi compactada entremezclada con ceniza de color gris y fragmentos de cerámica. Tiene un contorno elaborado sobre la roca madre.
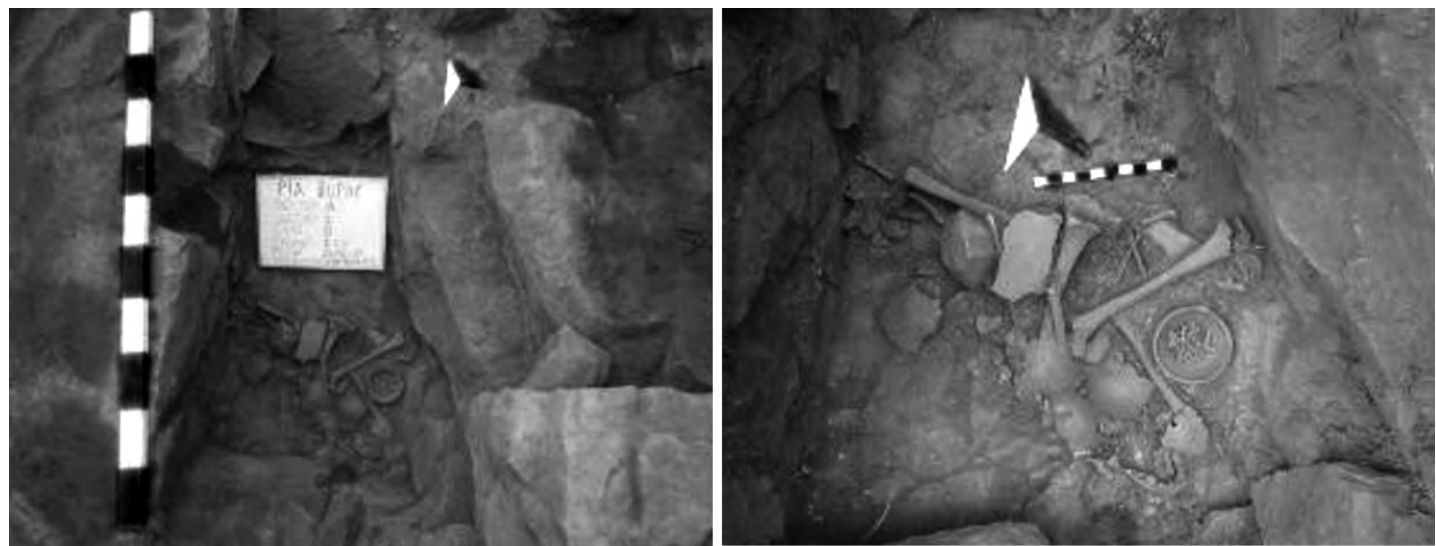

Figuras 12 y 13: Dos vistas del Contexto Funerario 1.

Individuo: Se trata de un entierro secundario hallado a $2.30 \mathrm{~m}$ de profundidad con respecto a la cota, corresponde a un infante de 7 años aproximadamente, de sexo femenino, las osamentas están desarticuladas, no se encuentra otras partes de su esqueleto, solo se puede apreciar algunas vértebras. El cráneo se encuentra fragmentado en 7 partes, la mandíbula y maxilar están dispersos en un área de más de $0.30 \mathrm{~m}$, probablemente como parte de una actividad ritual. Sobre el cuerpo se encontraba un relleno de $0.70 \mathrm{~m}$ aproximadamente de grosor.

Materiales Asociados: Presenta dos elementos. El Elemento 1: cuenco cerámico que presenta una pequeña fractura en el borde, el diámetro del cuerpo es $0.23 \mathrm{~m}$, el diámetro de la boca es $0.19 \mathrm{~m}$. Elemento 2: conjunto de 7 cuentas de $3 \mathrm{~cm}$ de largo y $1.5 \mathrm{~cm}$ de ancho, elaboradas a base de material óseo. Se encuentran debajo de la osamenta del individuo. 

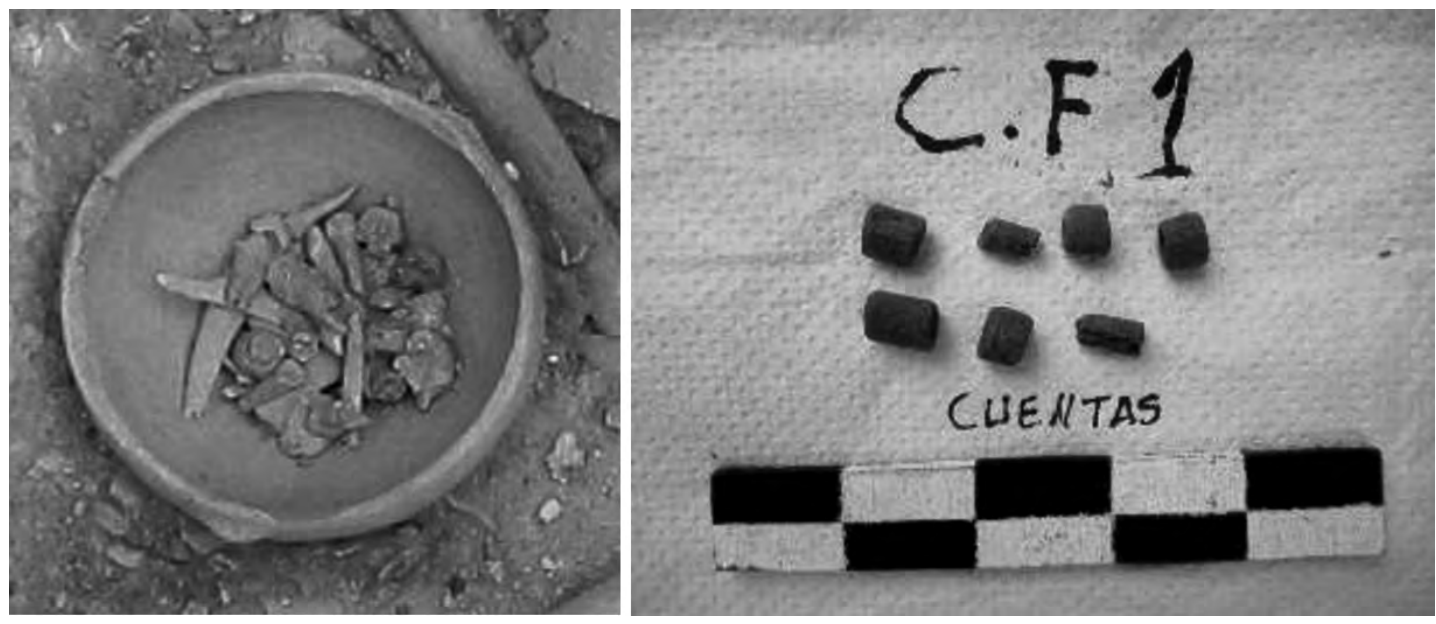

Figuras 14 y 15: A la izquierda el elemento $N^{\circ} 1$, a la derecha el elemento $N^{\circ} 2$

\section{2.- UNIDAD 3:}

Se encuentra emplazada en el interior del edificio $\mathrm{N}^{\circ} 1$, del sector $\mathrm{A}$, sobre una plataforma aterrazada. Esta trinchera abarca la totalidad del espacio interno del edificio, con un ancho de $2 \mathrm{~m}$ en dirección E-W por 12m de largo en dirección N-S, ubicándose el datum en las coordenadas UTM: 8747422N y 0303109E; a un altura de 3524 m.s.n.m. y una profundidad máxima de excavación de 0.74m.

El edificio se caracteriza por estar emplazado sobre una terraza artificial, apoyando sus muros en la roca geológica, que a su vez funciona como la base estructural, adaptándose al relieve del mismo. Se trata de un edificio administrativo, centro de poder, asociado a un patio. El edificio presenta una planta irregular, cuyos materiales de construcción son la piedra canteada, estas a su vez unidas con argamasa de arcilla y enlucidas con la misma arcilla para posteriormente ser pintadas, con un largo máximo de $13.15 \mathrm{~m}$, un ancho máximo de $3.80 \mathrm{~m}$ y una altura que oscila entre $1.90 \mathrm{~m}$ y $4.30 \mathrm{~m}$. Entre sus elementos arquitectónicos podemos mencionar la presencia de tres muros de forma irregular (semi-rectangulares). Estos paramentos contienen nichos: 29 de forma rectangular y cuadrangular en el interior y otros más pequeños en las columnas externas; contenían en el interior osamenta humana (cráneos y huesos largos), así como objetos rituales contemporáneos (coca, cigarro, caña). Otros elementos visibles vienen a ser las 6 columnas, las cuales dan origen a los 6 vanos continuos de forma trapezoidal. Estos vanos presentan dinteles rectangulares, en algunos casos muy próximos a clavos de piedra. El tipo de mampostería es ordinaria, con argamasa de arcilla, sus esquinas son adosadas y en otros casos concertadas. No presenta escalinatas. Su cubierta es de lajas de piedra de forma rectangular con las esquinas redondeadas, con una torta de arcilla sobre esta, permitiendo que en el edifico no se filtre el agua de las lluvias. Su cimentación es continua compuesto por ciclópeos y conglomerado. El piso del edifico es de arcilla, presenta cortes por efectos de huaqueo. El edifico no presenta decoración. El estado de conservación es regular, presenta grafitis modernos, derrumbe hacia el lado sur del paramento 3, filtraciones de agua por pérdida de argamasa de arcilla que cubría las lajas de piedra.

Las excavaciones de esta unidad se hicieron tanto en el interior como el exterior del edificio $\mathrm{N}^{\circ} 1$. Se planteó una trinchera de $10 \mathrm{~m}$ de largo por $2 \mathrm{~m}$ de ancho. La capa superficial en el exterior estaba compuesta por vegetación; en el interior se trataba de tierra y basura moderna. Una vez registrado el edificio tal y cual lo encontramos se procedió a las excavaciones. La capa A, conformada por tierra 
arqueológico en el interior del edificio: 3 hallazgos (1 chancador, 1 piruro y un artefacto óseo para calero). Ya en la capa B, compuesta por tierra de color marrón claro, se identificó quemas, lentes de ceniza, un hallazgo (asta de taruca) puesto como ofrenda en la base de la columna $\mathrm{N}^{\circ} 6$; y el CF-1. La capa C, está compuesta de arcilla de color beige (piso), presenta 6 hallazgos: 2 piruros (uno de cerámica y el otro de osamenta animal), 1 percutor, un mano de moler, un artefacto lítico y un asta de taruca; así mismo se aprecia las quemas 3, 4, 5, 6, 7 y 8, las cuales eran netamente arqueológicas, ya que estaban asociadas a fragmentos de cerámica y no presentaban rasgos de estar descontextualizadas. Como rellenos o deposiciones culturales se identificaron fragmentos de cerámica local de pasta marrón oscuro con engobe rojo o negro pulido, además de fragmentos inca local. Finalmente se pudo apreciar la roca geológica, en la cual descansan los muros y cimientos de la edificación.

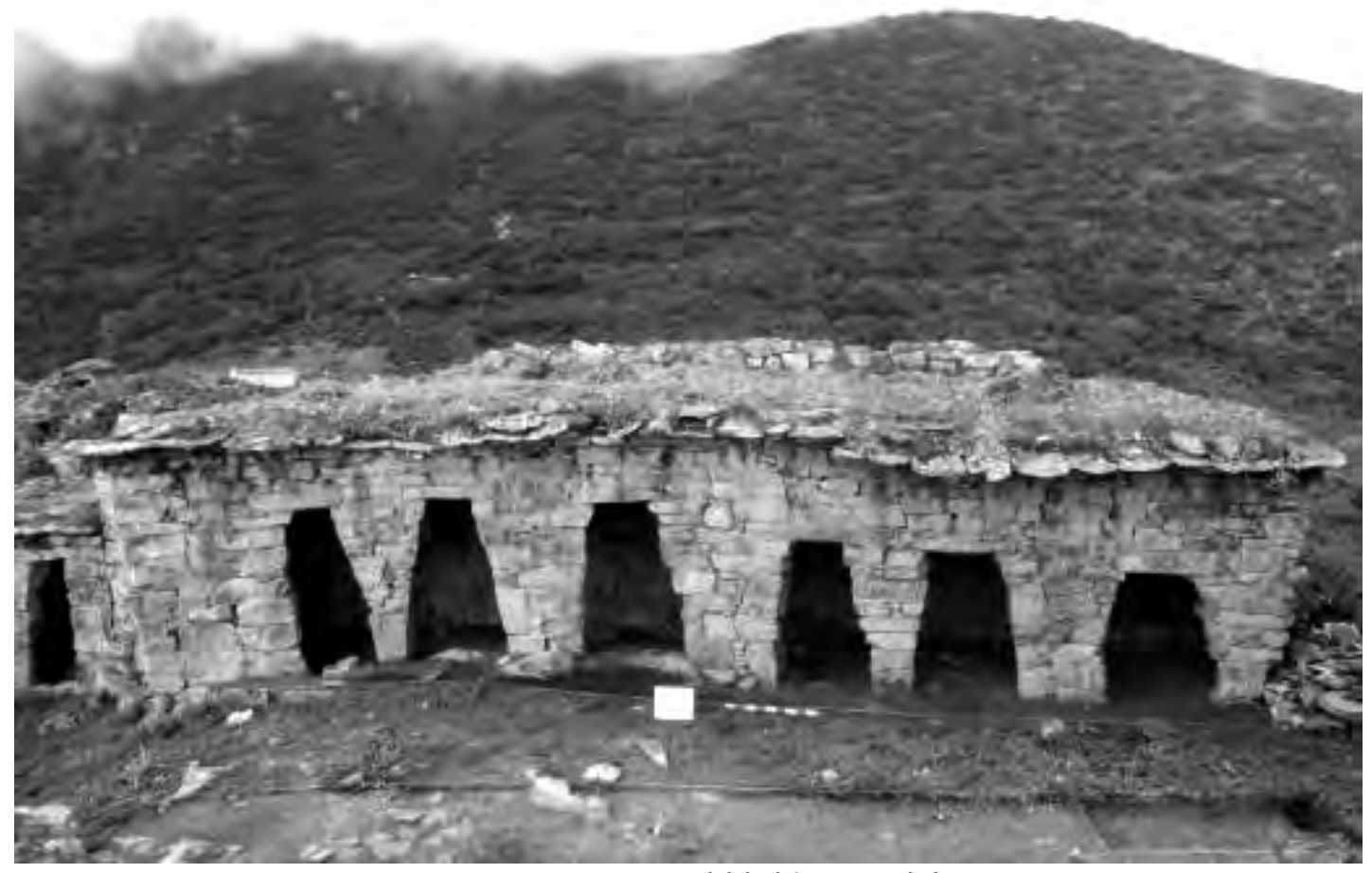

Figura 16: Vista general del edificio 1, unidad 3.
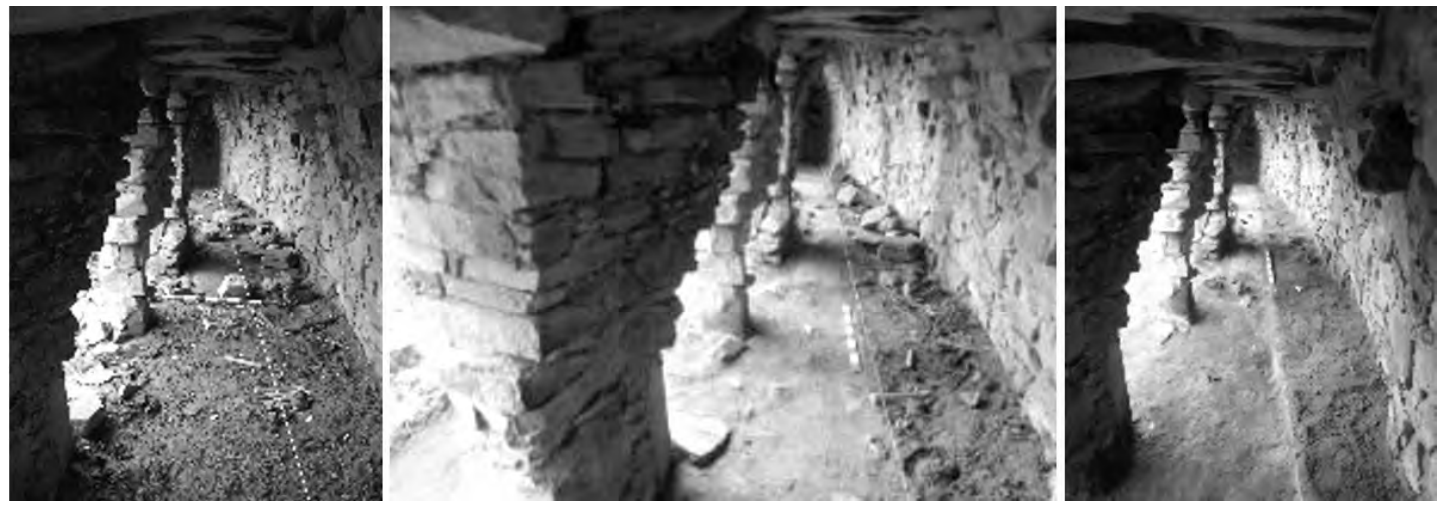

Figuras 17, 18 y 19: De izquierda a derecha vista panorámica de la Capa superficial, capa A y capa B, unidad 3. 

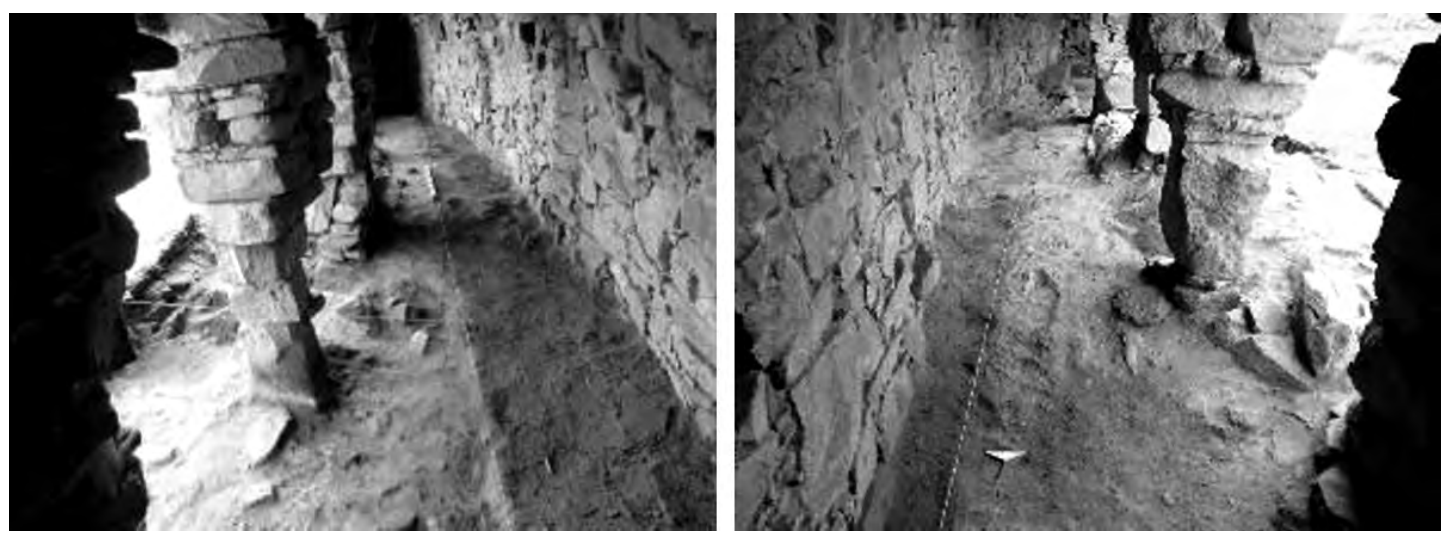

Figuras 20 y 21: A la izquierda capa C, a la derecha capa D (roca geológica).

Contexto Funerario $\mathrm{N}^{\circ}$ 1: El contexto funerario 1 está ubicado hacia el sur-oeste de la unidad, al pie de la columna $\mathrm{N}^{\circ} 5$, adosado al basamento; a unos $0.77 \mathrm{~m}$ de profundidad con respecto a la superficie. Ubicado al exterior de la edificación, próximo al vano de acceso $\mathrm{N}^{\circ} 6$.

Estructura Funeraria: se trata de una cista de forma irregular alargada de NE a SW, elaborada en base a piedras canteadas angulosas dispuestas en una sola hilera irregular, a su vez cubierta por arcilla a manera de argamasa, cuyo largo máximo es de $0.60 \mathrm{~m}(\mathrm{~N}-\mathrm{S})$, un ancho máximo de $0.30 \mathrm{~m}$ (E-W) y una profundidad de $0.15 \mathrm{~m}$.

Individuo: se trata de un entierro secundario e individual, las osamentas están desarticuladas e incompletas. El sexo del individuo es masculino infante entre los 3 a 5 años de edad aproximadamente. La posición del cuerpo no se puede determinar, sin embargo se puede medir y ver la orientación del entierro; el largo máximo es de $0.60 \mathrm{~m}$ en dirección N-S y el ancho máximo es de $0.30 \mathrm{~m}$ en dirección E-W. No presenta el cráneo completo, solo se aprecia un fragmento de la órbita ocular, entre otros huesos.

Materiales Asociados: se identificaron un total de 5 fragmentos de cerámica asociados al individuo a unos $0.05 \mathrm{~m}$ al oeste, 2 osamentas de animal, una costilla y una vértebra. Cabe resaltar que se pudo identificar un fragmento de cerámica correspondiente al estilo Inca, el cual era parte del relleno de arcilla que cubría la cista.
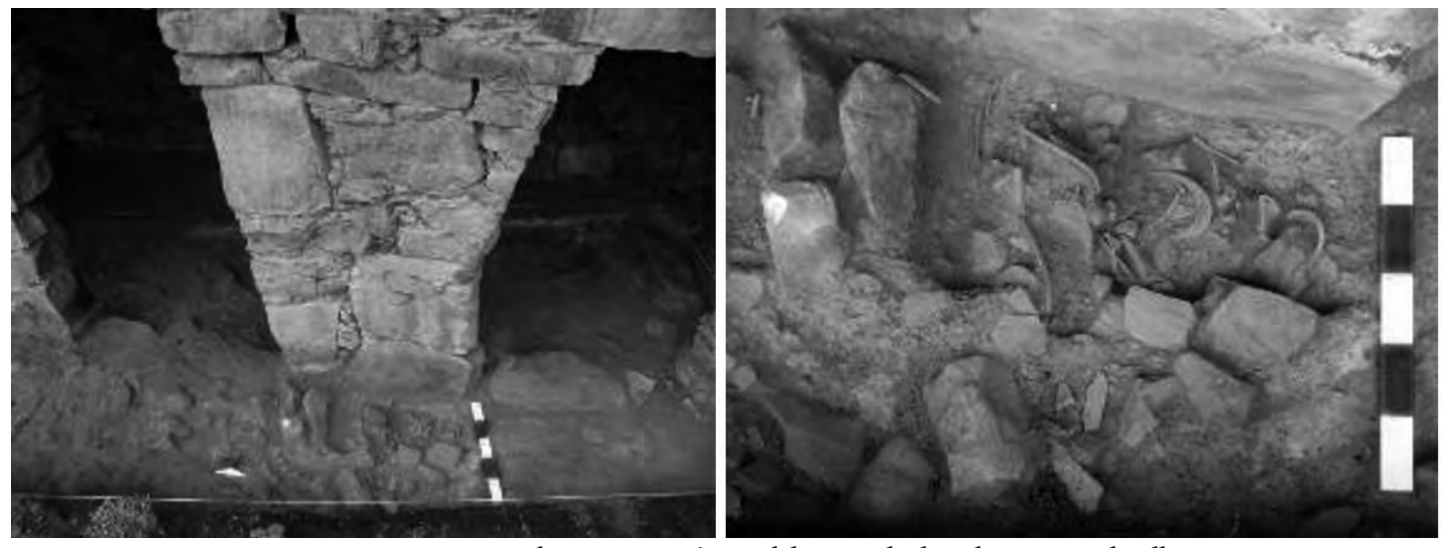

Figuras 22 y 23: Izquierda vista panorámica del CF-1; a la derecha vista en detalle. 
La estratigrafía que contenía el CF-1, no presenta intrusiones ni descontextualización, al parecer esta fue la forma de enterrar a este individuo. El estado de conservación de las osamentas es regular, se habría logrado preservar por la arcilla que la cubría, como un aislante de la humedad.

\section{3.- UNIDAD 6:}

Se encuentra ubicado en el interior de un edificio y está emplazada sobre un terreno irregular en el cual se puede observar un desnivel de $40^{\circ}$ aproximadamente hacia el lado norte. Como referencia podemos mencionar que dicha unidad se sitúa al norte de la unidad $N^{\circ} 02$. Presenta las siguientes coordenadas: $8747450 \mathrm{~N}$ y $0303061 \mathrm{E}$ y a una altura de 3534 m.s.n.m. Se encuentra orientada de norte a sur y mide $8.00 \mathrm{~m}$ de largo por $8.00 \mathrm{~m}$ de ancho; la profundidad máxima de excavación es de $1.70 \mathrm{~m}$.

El edificio se encuentra emplazado sobre un terreno irregular, presenta una planta rectangular y está orientado de sur a norte. Su único acceso se ubica en la parte media del Muro $\mathrm{N}^{\circ}$ 01, situado hacia el lado sur del edificio; dicho vano posee forma rectangular y mide $0.60 \mathrm{~m}$ de largo por $0.73 \mathrm{~m}$ de alto y $0.43 \mathrm{~m}$ de grosor. Hacia la parte exterior del vano se identificó una pequeña estructura de planta irregular (chullpa), la cual restringe el ingreso. A pesar de su mal estado de conservación, podemos mencionar que el acceso de esta estructura (tipo antecámara) debió ubicarse hacia el lado este. Por lo tanto, se comprende que para acceder al edificio se debe ingresar por un primer vano orientado de este a oeste hasta la antecámara y seguidamente, por otro vano orientado de sur a norte. Asimismo, por las dimensiones de la primera estructura el ingreso debió realizarse en cuclillas. Hacia la parte interna del vano de acceso al edificio se observa un desnivel de $1.00 \mathrm{~m}$ aproximadamente, para facilitar el acceso se utilizó un peldaño situado a $0.50 \mathrm{~m}$ del nivel del suelo. El primer espacio al cual uno accede fue registrado como el Recinto $\mathrm{N}^{\circ} 01$, el cual posee una planta cuadrangular de 4.26 de largo y 4.22 de ancho.

Hacia su lado sureste se ubica un conjunto de cámaras distribuidas por niveles, estas presentan una planta rectangular de $2.06 \mathrm{~m}$ de largo y $1.55 \mathrm{~m}$ de ancho aprox. Los tres niveles de cámaras poseen un vano de forma rectangular, orientados al oeste; los niveles fueron registrados de abajo hacia arriba. Dicha estructura se ubica en la esquina que conforman los muros № 01 (lado sur) y № 04 (lado norte), y agregándose hacia el lado oeste el muro № 09 y hacia el lado norte el muro № 08 . En la parte alta del paramento sur del muro № 01 se identificó un ducto cuadrangular el cual permite el ingreso de aire y de iluminación hacia la parte interna del edificio. Asimismo, en los distintos muros que conforman el Recinto $\mathrm{N}^{\circ} 01$ se puede observar nichos de diversas formas y dimensiones, así como voladizos. Hacia la esquina noroeste, entre los muros $\mathrm{N}^{\circ} 02$ y $\mathrm{N}^{\circ} 03$ se identificó una pequeña cámara de planta rectangular. Hacia el lado norte del Recinto $\mathrm{N}^{\circ} 01$ se ubica el muro $\mathrm{N}^{\circ} 03$, el cual en su parte media se sitúa el vano $\mathrm{N}^{\circ} 02$ de planta rectangular de $0.51 \mathrm{~m}$ de ancho por $0.76 \mathrm{~m}$ de alto y $0.34 \mathrm{~m}$ de grosor; por este vano se accede al Recinto $\mathrm{N}^{\circ} 02$. Esta última estructura presenta una planta rectangular de $3.89 \mathrm{~m}$ de largo por $1.40 \mathrm{~m}$ de ancho; y está conformada por los siguientes muros: hacia el lado sur por el muro № 03, hacia el lado oeste por el muro № 05, por el norte por el muro № 06 y hacia el este por el muro № 07.

En su parte interna, hacia su esquina noroeste se identificó una cista funeraria. Debido a su mal estado de conservación, no se logró identificar ningún nivel de cámaras. El edificio está conformado por diversos muros de tipo simple, cuya funcionalidad es la conformación y diferenciación de espacios. Estos muros poseen doble cara y un relleno o núcleo a base de tierra arcillosa y grava (mediana y grande). El material constructivo utilizado son las piedras canteadas de diversos tamaños, las cuales no presentan acabado (sin trabajo), sin embargo se observa las caras más planas hacia los paramen- 
tos, sobre todo hacia la parte exterior del edificio. Las piedras canteadas fueron unidas con mortero de arcilla amarilla y como desgrasante utilizan las fibras vegetales, y para la cubierta se hiso uso de grandes lajas.

Los diversos muros presentan una mampostería a base de hiladas arbitrarias las cuales varían en grosor, generando grandes espacios entre los elementos pétreos. En dichos espacios se colocaron diversas pachillas (piedras planas de pequeño tamaño) para mejorar la estabilidad de las estructuras. Hacia la parte exterior del edificio los muros presentan un perfil semi curvo y esquinas rectas; este patrón se pierde totalmente hacia el lado interno debido a que las esquinas se vuelven curvas al igual que los perfiles de los muros, lo que permite que a mayor altura el grosor de los muros vaya aumentando progresivamente y así ser utilizado como base para la cubierta; este sistema estructural es conocido como falsa bóveda o falso arco. De lo expuesto líneas arriba se comprende que el edificio excavado en la unidad № 06 está conformado por el Recinto № 01, tres niveles de cámaras y el Recinto № 02. Hacia el lado este del edificio se identificó un espacio abierto.

Su estado de conservación es malo, el edificio se encuentra destruido en un $40 \%$ dicha pérdida se encuentra situada hacia el lado norte y este. Los principales problemas ocasionados por los factores físico - químicos son la filtración y pluviosidad, debido a que las fuertes lluvias va debilitando cada vez más la torta de barro colocada sobre la cubierta lo que genera una fuerte filtración hacia el interior del edificio. Por otro lado, el alto nivel de humedad permite el desarrollo de los microorganismos como líquenes y hongos, los cuales se asientan sobre los paramentos de los muros. En cuanto a los macro organismos, específicamente la flora, se observa la presencia de vegetación herbácea sobre la cubierta y arbustiva sobre la cabecera actual de los muros, en algunos casos también en los paramentos ocasionando la pérdida del mortero.

En el deterioro estructural se identificó fisuras verticales y horizontales, grietas y rajaduras en la cubierta y en los paramentos. Los muros № 04 y № 06 se encuentran pandeados y el muro № 07 solo fue identificado en su lado oeste; el dintel de su vano principal se encuentra fracturado, así como las lajas de la cubierta. El edificio tiene altos índices de probabilidad de desplomarse por completo.

La secuencia estratigráfica identificada en la unidad Nº 06 será descrita detalladamente desde lo más reciente hasta lo más antiguo, en sentido inverso a su formación. Asimismo, se tendrá en cuenta los espacios arquitectónicos diferenciados. La primera capa identificada fue la superficial, la cual cubría completamente a la unidad y se caracterizaba por la vegetación herbácea propia de la zona de origen natural. La capa superficial cubre a la capa A, la cual es el derrumbe de los Muros $\mathrm{N}^{\circ} 02, \mathrm{~N}^{\circ}$ $03, \mathrm{~N}^{\circ} 04, \mathrm{~N}^{\circ} 05, \mathrm{~N}^{\circ} 06, \mathrm{~N}^{\circ} 07, \mathrm{~N}^{\circ} 08$; los cuales conforman los Recintos $\mathrm{N}^{\circ} 01 \mathrm{y} \mathrm{N}^{\circ} 02$. Al retirar esta capa se identificaron diversas capas las cuales serán descritas diferenciadas según su espacio de ubicación. Hacia el extremo suroeste de la unidad, hacia la parte exterior del Recinto $\mathrm{N}^{\circ} 01$ después de haber retirado la capa A se registró la capa B interpretada como el Apisonado $\mathrm{N}^{\circ} 01$; esta última capa se encuentra al mismo nivel de la cubierta de la Estructura $\mathrm{N}^{\circ} 01$. Al interior de dicha Estructura se registró la capa $\mathrm{E}$.

El Apisonado $\mathrm{N}^{\circ} 01$ cubre a la roca madre o capa H; por otro lado la Capa D fue registrada como el Apisonado $\mathrm{N}^{\circ} 02$ ya que fue utilizado como la superficie de la Estructura $\mathrm{N}^{\circ} 01$. Hacia el extremo sureste de la unidad (parte exterior) se retiró la capa $\mathrm{A}$, identificándose la capa $\mathrm{C}$, la cual cubre a la roca madre (capa H). Al interior del Recinto $\mathrm{N}^{\circ} 01$ se retiró parte de la capa A y después se realizó un Cateo en su lado suroeste. Después de la capa A se identificó la capa J, la cual cubre a la capa K; esta última cubre a la capa L que cubre al Piso empedrado $\mathrm{N}^{\circ} 02$. El piso cubre a la capa M. 

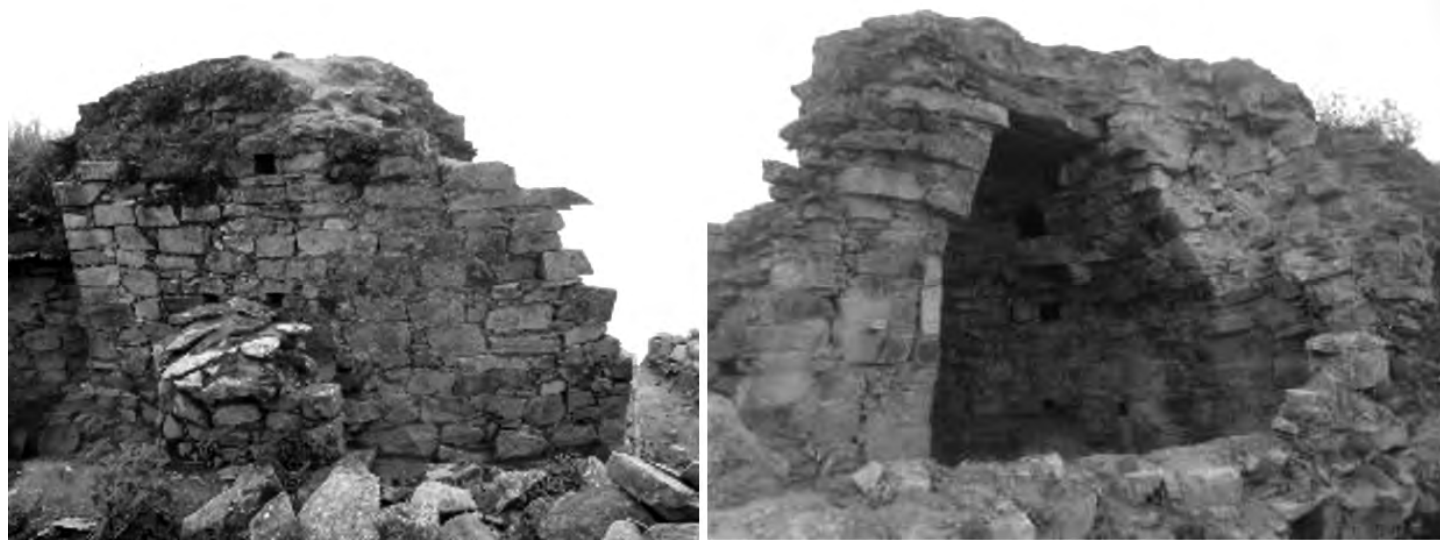

Figuras 24 y 25: A la izquierda frontis del edificio; a la derecha vista panorámica del edifico en su lado norte.
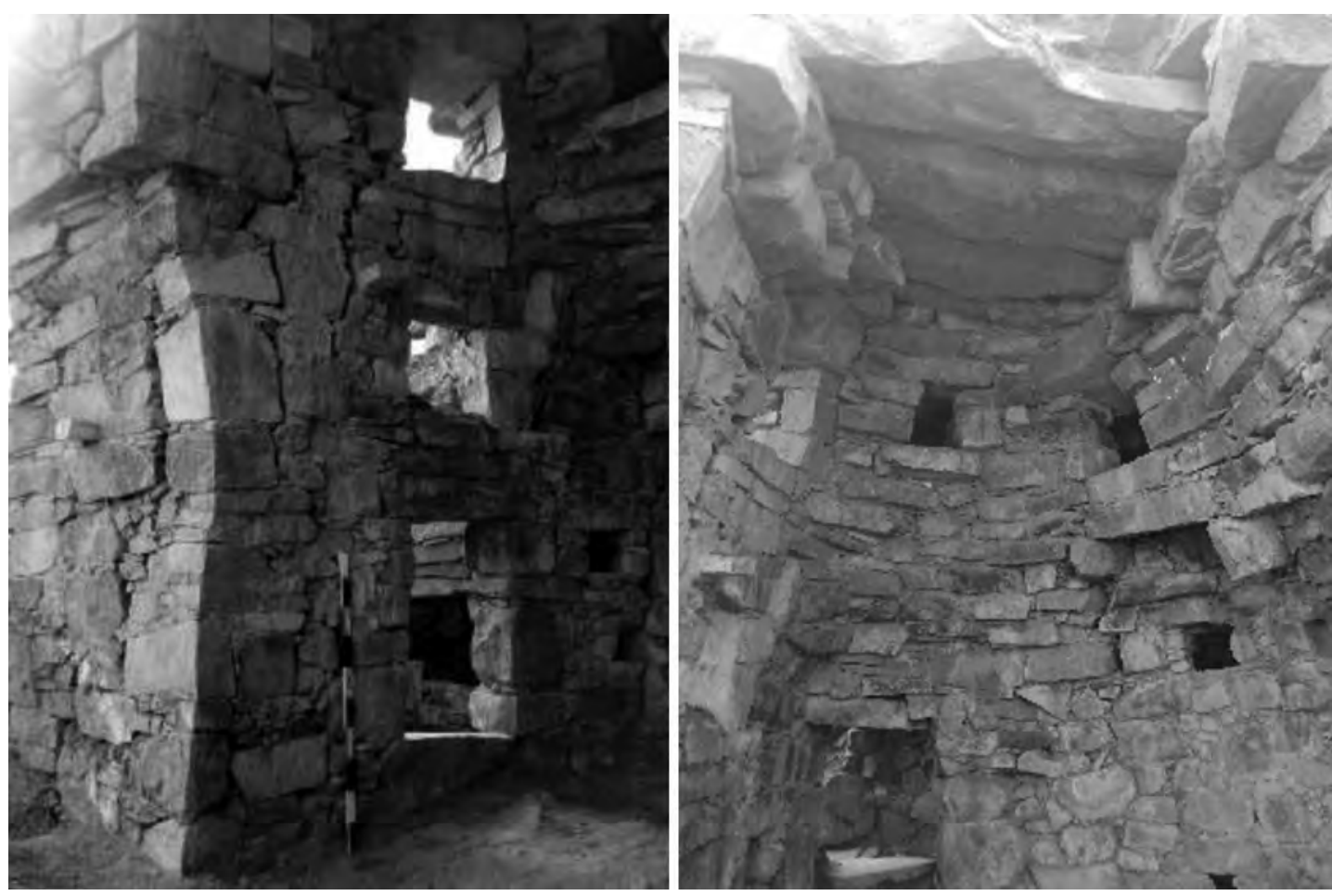

Figuras 26 y 27: A la izquierda vista panorámica de los tres niveles de cámaras, ubicados hacia el lado sureste del Recinto $N^{\circ} 01$. A la derecha interior del edificio

El Recinto $\mathrm{N}^{\circ} 02$ presenta la siguiente estratigrafía: al excavar la capa A se logró identificar la capa F la cual está contenida en la cista del Contexto Funerario $\mathrm{N}^{\circ} 02$ y la capa $\mathrm{G}$ o Apisonado $\mathrm{N}^{\circ} 03$. La capa G cubre a la capa I, la cual está contenida en la estructura subterránea. En cuanto a los hallazgos; en la capa A, tenemos: H-3 (semillas de maíz), H-4 (artefacto lítico tallado, con motivos zoomorfos de renacuajos), $\mathrm{H}-5$ (chancador y piruro), H-10 (chancador), H-11 (mano de moler), H-12 (tres elementos de metal: cobre). En la capa B, tenemos: H-1 (proyectil de material lítico), H-2 (mortero de material lítico). En la capa C, tenemos: H-6 (mortero), H-7 (mano de moler), H-8 (piruro). En la capa D, tenemos: 
H-9 (piruro). En la capa E, tenemos: H-13 (2 elementos metálicos de cobre, denominados agujarrieros, un fragmento de cerámica y dos osamentas; todos a manera de ofrenda). En la capa F, tenemos: el CF2. En la capa I, tenemos: H-14 (fragmentos de una vasija, a manera de ofrenda, asociado a la construcción del muro 3). En la capa K, tenemos: el H-15, 16 y 17(piruros); y por último en la capa L, tenemos: el H-16 (chancador).
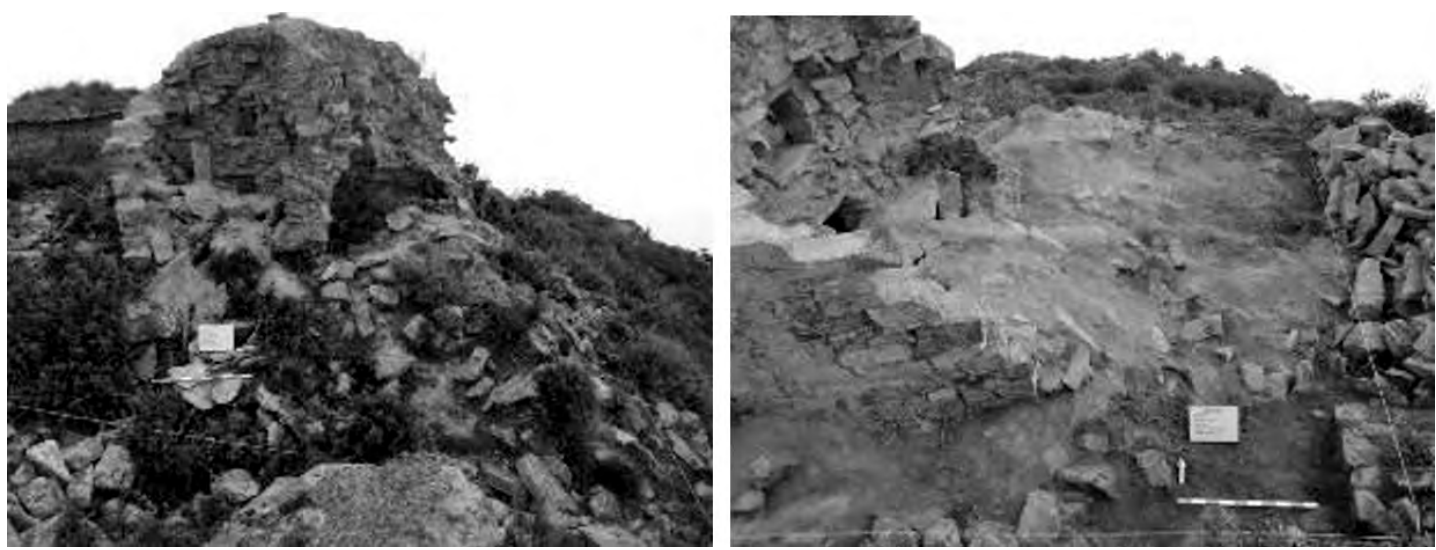

Figuras 28 y 29: A la izquierda capa superficial, a la derecha capa A.

Contexto Funerario $\mathrm{N}^{\circ} 1$ : El Contexto Funerario $\mathrm{N}^{\circ} 01$ se ubica hacia el lado noroeste dentro del Recinto $\mathrm{N}^{\circ} 01$ y se encuentra asociado al paramento este del Muro $\mathrm{N}^{\circ} 02$.

Estructura Funeraria: no presenta, ya que se encuentra depositada sobre el lecho de tierra de color beige.

Individuo: El contexto se orienta de sur a norte, el tipo de entierro es individual, el estado del cuerpo es desarticulado y abarca un área de $0.75 \mathrm{~m}$ de largo y un ancho de $0.40 \mathrm{~m}$. Los huesos que lo constituyen se disponen de la siguiente manera: hacia el lado norte se ubica parte del cráneo y algunas costillas (dos fragmentos); en la parte central se divisa los huesos largos (fémur y tibias) y hacia el lado sur se identificó una coxis fragmentada (lado izquierdo) acompañada de costillas. Al retirar este conjunto de óseos, se registró en la parte central una vértebra y cadera animal, aparentemente de camélidos. El contexto funerario $\mathrm{N}^{\circ} 01$ corresponde a por lo menos dos individuos: una mujer adulta y una niña. Por la ubicación de los óseos podemos mencionar que dicho entierro debió ser colocado en algún espacio dentro del Kullpi $\mathrm{N}^{\circ} 01$ (Recinto $\mathrm{N}^{\circ} 01-\mathrm{N}^{\circ} 02$ ).

Materiales Asociados: debido al traslado y el desarticulamiento del esqueleto, por ende se presume que fue extraído de su lugar original, no se halló objetos asociados, correspondería a un entierro secundario.

Contexto Funerario $\mathrm{N}^{\circ} 2$ : El Contexto Funerario 2, se ubica dentro del Recinto $\mathrm{N}^{\circ} 02$ y se encuentra asociado al paramento este del Muro $\mathrm{N}^{\circ} 05$.

Estructura Funeraria: Los cuerpos fueron depositados dentro de una cista de planta rectangular de $0.55 \mathrm{~m}$ de largo y $0.45 \mathrm{~m}$ de ancho.

Individuo: El contexto se orienta de suroeste a noreste, el tipo de entierro es múltiple, la posición del cuerpo desarticulado y abarca un área de $0.42 \mathrm{~m}$ de largo y un ancho de $0.40 \mathrm{~m}$. El Contexto se orienta de suroeste a noreste y está conformado por diversos individuos de distintas edades. Hacia el 

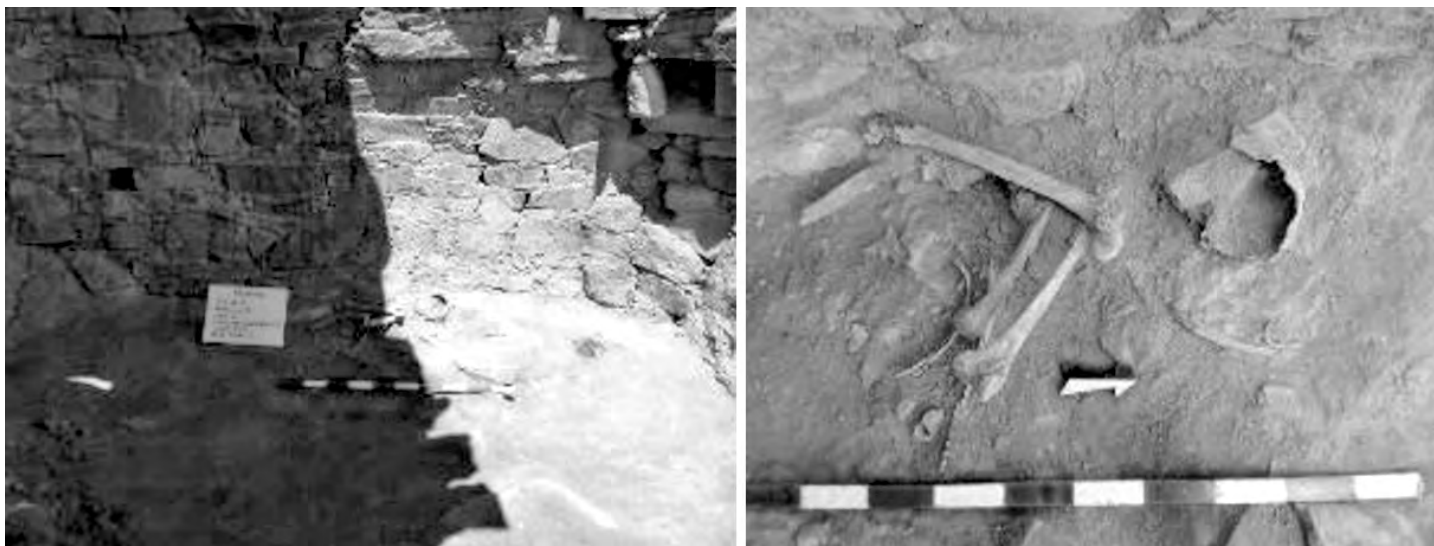

Figuras 30 y 31: A la izquierda vista panorámica, asociado al muro $N^{\circ} 02$, a la derecha vista en detalle del Contexto Funerario 1.

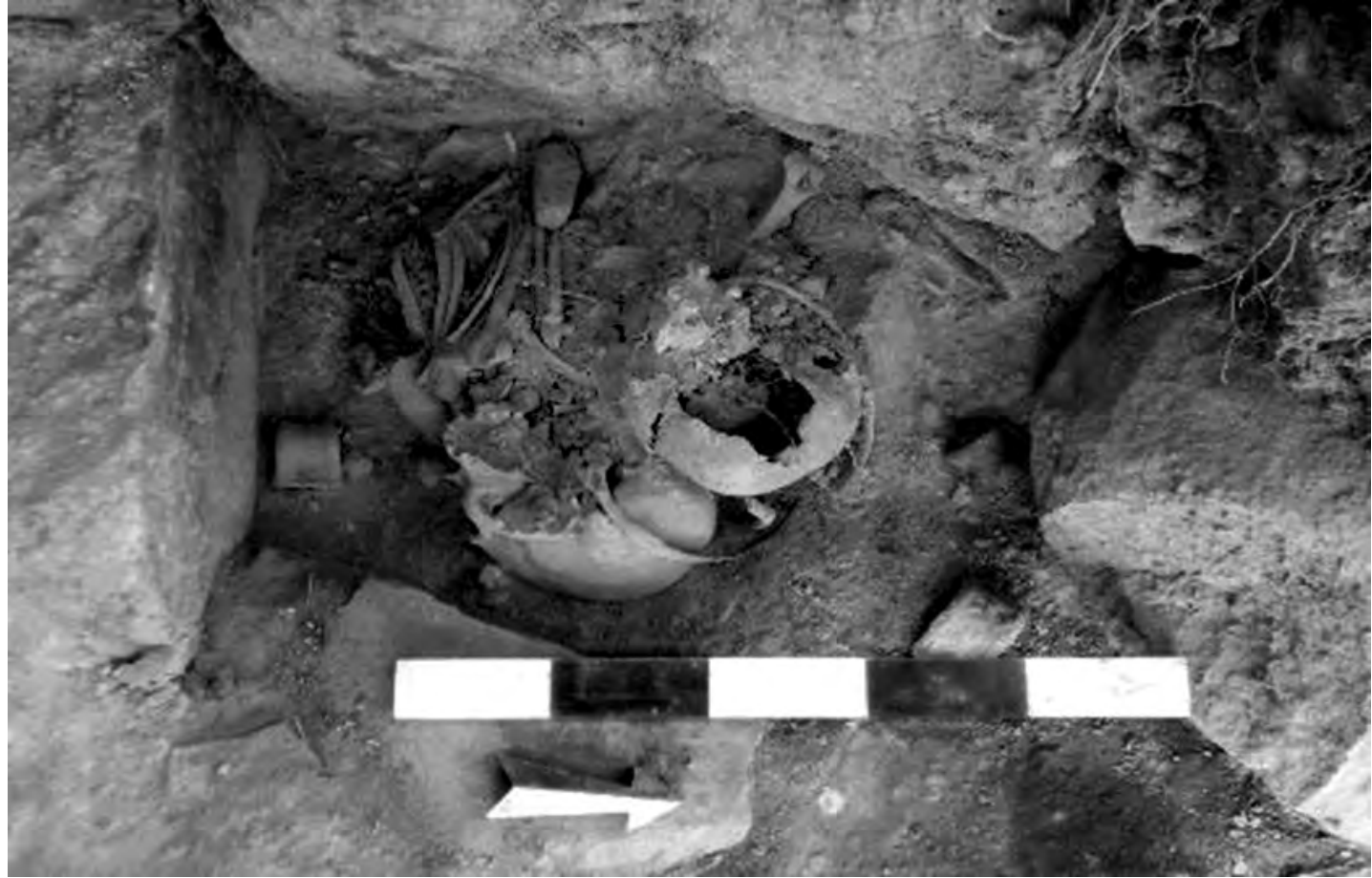

Figura 32: Vista en planta del Contexto Funerario $N^{\circ} 02$.

hacia el extremo sureste un coxis y en el espacio de separación un conglomerado de costillas y huesos largos. Hacia el lado noroeste se recuperó un cráneo fragmentado de mujer adulta orientado de suroeste a noreste, el cual está rodeado de costillas; en el lado noreste se registró otro cráneo con la misma orientación dispuesta de costado. Al retirar el cráneo del noroeste se divisó una mandíbula (maxilar inferior) de un infante y dentro de ella se recuperó diversos huesos largos de adulto. Así mismo, se recuperó una vértebra animal (camélido). El contexto funerario $\mathrm{N}^{\circ} 02$ está constituido por un mínimo de tres individuos (dos cráneos adultos y un infante); los cuales fueron depositados dentro de una cista. Dicho contexto se encuentra alterado.

Materiales Asociados: se identificó fragmentos de cerámica, asas de vasijas. 


\section{4.- UNIDAD 14:}

Se sitúa en el sector "A" y está emplazado en un terreno plano. Como referencia podemos mencionar que esta unidad se encuentra al noroeste de la unidad $\mathrm{N}^{\circ} 09$, la cual se emplaza frente al edificio $\mathrm{N}^{\circ}$ 04; la unidad se caracteriza por abarcar dos espacios distintos, separados en sub-unidades, el primero abarca una parte del patio central entre recintos (sub-unidad $\mathrm{N}^{\circ} 01$ ); y el segundo, un recinto de planta ovalada (sub-unidad $\mathrm{N}^{\circ}$ 02). Sus coordenadas son: $8747425 \mathrm{~N}-0303075 \mathrm{E}$ con una altura de $3518 \mathrm{msnm}$, con dimensiones de $5 \mathrm{~m}$ de largo por $5 \mathrm{~m}$ de ancho.

\section{Recinto $\mathrm{N}^{\circ} 01$ :}

Se sitúa próximo a la esquina este de la unidad, emplaza la subunidad 1. Se trata de una unidad habitacional de planta irregular; sus dimensiones son: 4.10 metros (W a E), 3.30 metros (S a N) y 2.10 metros de alto. El material constructivo empleado está conformado por piedras canteadas, pachillas y mortero de arcilla. Los muros que conforman el recinto son de forma recta por fuera y curvos internamente, en total se contabilizaron 6 muros los cuales son concertados entre ellos en las esquinas, estos se distribuyen formando un espacio central con cámaras en dos niveles en los lados internos NE y SE; la técnica que se empleó en la construcción de tales muros es la mampostería del tipo concertado. El vano se encuentra en el lado SW, la forma no se pudo definir ya que se encuentra destruido; sus dimensiones son: un alto conservado de $0.50 \mathrm{~m}, 0.50 \mathrm{~m}$ de ancho y $0.26 \mathrm{~m}$ de grosor.

Nichos o cámaras: Se presentan en total 5 cámaras situadas en dos niveles, Dichas cámaras están divididas de la siguiente manera, dos cámaras en el muro NE y tres cámaras en el muro SE. En el muro NE (formado por los muros $\mathrm{N}^{\circ} 04$ y 06), se encuentra la cámara $\mathrm{N}^{\circ} 02$ y 03. La cámara $\mathrm{N}^{\circ} 02$ es de planta en "D" y alargada, mide 1.40 metros de largo, 1.60 metros de ancho $0.90 \mathrm{~m}$ de alto, se encuentra orientado al oeste; su vano mide $0.40 \mathrm{~m}$ de ancho, $0.50 \mathrm{~m}$ de alto y $0.20 \mathrm{~m}$ de grosor; en el interior de dicha cámara no se encontró material cultural. La cámara $\mathrm{N}^{\circ} 03$ está en un segundo nivel con respecto a la cámara $\mathrm{N}^{\circ} 02$, es de planta en "D", sus dimensiones son: 1.85 metros de largo, 0.70m de ancho y $0.70 \mathrm{~m}$ de altura; esta cámara se encuentra orientada al oeste; en su interior se registró fragmentos de cerámica, restos óseos, así como también el hallazgo $\mathrm{N}^{\circ} 05$ (artefactos líticos); por lo tanto se puede definir que se trata de un espacio para guardar utillajes.

En el lado SE (formado por los muros $\mathrm{N}^{\circ} 03$ y 05) se encuentran las cámaras $\mathrm{N}^{\circ} 04,05$ y 06. La cámara $\mathrm{N}^{\circ} 04$ se encuentra en el extremo SW, se trata de una cámara de planta rectangular, orientada al norte; sus dimensiones son: $0.96 \mathrm{~m}$ de ancho, $0.85 \mathrm{~m}$, de alto y $0.49 \mathrm{~m}$ de alto; su vano mide $0.56 \mathrm{~m}$ de ancho, $0.85 \mathrm{~m}$ de alto y $0.17 \mathrm{~m}$ de grosor; funcionalmente se le atribuye que fue una cámara funeraria, ya que en su interior se registró el contexto funerario $\mathrm{N}^{\circ} 01$. La cámara $\mathrm{N}^{\circ} 05$ se encuentra al lado SE de la cámara $\mathrm{N}^{\circ} 04$, se trata de una cámara de planta rectangular la cual se encuentra orientada al norte; sus dimensiones son: $0.96 \mathrm{~m}$ de ancho, $0.93 \mathrm{~m}$ de alto y $0.43 \mathrm{~m}$ de alto; su vano mide $0.58 \mathrm{~m}$ de ancho, $0.93 \mathrm{~m}$ de alto y $0.20 \mathrm{~m}$ de grosor; funcionalmente se le atribuye que fue una cámara funeraria, ya que en su interior se encontró un fragmento óseo humano. La cámara $\mathrm{N}^{\circ} 06$ se encuentra formando un segundo nivel con respecto a las cámaras $\mathrm{N}^{\circ} 04$ y 05, se trata de una cámara de planta rectangular, su dimensiones son: $1.40 \mathrm{~m}$ de ancho, $0.78 \mathrm{~m}$ de alto conservado y $0.58 \mathrm{~m}$ de profundidad, esta cámara se encuentra orientada al norte; en su interior se registró el hallazgo $\mathrm{N}^{\circ} 06$ (proyectil); funcionalmente se le puede atribuir que fue un espacio dedicado a resguardar elementos utilitarios.

\section{Sub-unidad $\mathrm{N}^{\circ} 01$.}

La secuencia estratigráfica se presentará desde lo más antiguo hasta lo más moderno.

La capa final corresponde a una formación geológica, por lo tanto su formación es natural. La capa 

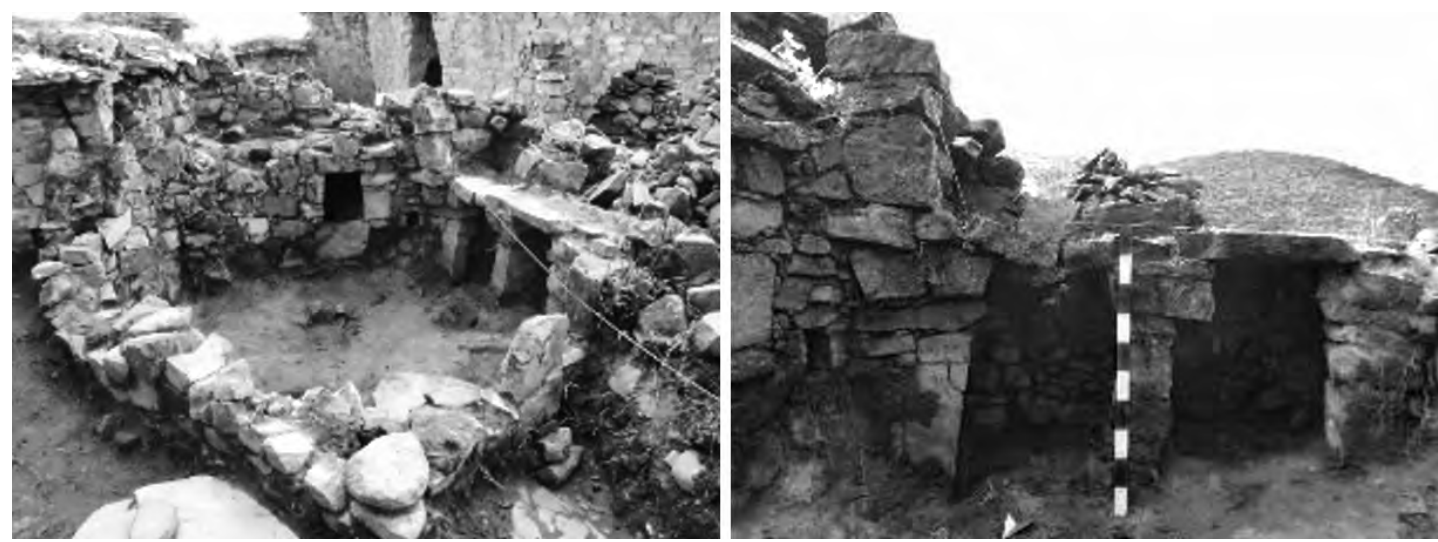

Figuras 33 y 34: A la izquierda recinto $N^{\circ} 1$. A la derecha: inferior derecha cámara $N^{\circ} 04$, inferior izquierdo cámara $N^{\circ} 05$ y superior cámara $\mathrm{N}^{\circ} 06$.

pequeñas, esto con el objetivo de nivelar el terreno. Funcionalmente sirvió como piso del espacio público o patio que emplaza la sub-unidad. La capa "B" fue cubierta por la capa "A" la cual se conforma de tierra arcillosa y piedras canteadas, producto de derrumbes de las estructuras que se asocian al espacio público. La capa "A" fue cubierta por la capa superficial, la cual está compuesta por tierra orgánica y vegetación herbácea de origen natural.

La sub-unidad 1, está representada por la parte externa de la edificación, es decir constituye el patio. El material recuperado de esta sub-unidad es mínima. En la capa superficial se registró una mediana cantidad de fragmentos de cerámica diagnóstica y no diagnóstica, también fragmentos de osamenta animal y humano. En la capa A, se registró aparte de fragmentos de cerámica diagnóstica y no diagnóstica: los fragmentos de osamenta animal y humano, los hallazgos 1 y 2: H-1 (una mano de moler y un batan), H-2 (un mortero). Finalmente en la capa B, se registró el H-8 (un chancador).

\section{Sub-unidad $\mathrm{N}^{\circ} 02$.}

La capa final está conformada por la roca madre, la cual corresponde a una formación geológica. Esta fue nivelada en algunas partes para servir como piso a la sub-unidad $\mathrm{N}^{\circ} 02$ (recinto $\mathrm{N}^{\circ}$ 01), ya que dentro de este recinto se observó que las actividades se dieron sobre la roca madre. Se definió como capa "B" al acumulamiento de arcilla que se encontró al interior de las cámaras N 02, 03, 04, 05 y 06. Posiblemente sea cultural, ya que en la cámara $\mathrm{N}^{\circ} 04$ se encontró el contexto $\mathrm{N}^{\circ} 01$ entremezclado con la arcilla; esta a su vez habría sido trasladada para servir como cubierta al CF-1. La capa "A" conjuntamente con la capa "B" cubren la capa final, pero se define que la capa "A" es más tardía ya que se trata de tierra arcillosa y piedras canteadas producto del derrumbe; esto causado por el colapso del recinto $\mathrm{N}^{\circ}$ 01. Finalmente la capa superficial cubre las capas “A” y "B”, la cual se trata de vegetación herbácea y tierra orgánica de origen natural, debido al abandono de los recintos.

En la sub-unidad 2, correspondiente al recinto 1 (interior), se pudo hallar: en la capa superficial abundantes fragmentos de cerámica diagnóstica y no diagnóstica, fragmentos de osamenta animal y humano. En la capa A, el H-3 (compuesto por dos piruros, un mortero, un chancador, un batan y una mano de moler), $\mathrm{H}-4$ (dos chancadores), $\mathrm{H}-5$ (en el interior de la cámara $\mathrm{N}^{\circ} 3$ se halló, un pulidor y una porra), H-6 (un proyectil), H-7 (dos piruros); así mismo un fogón y una quema, ambos arqueológicos, asociados a fragmentos de cerámica quemada. Finalmente en la capa B, se halló el CF-1.

Contexto funerario $\mathrm{N}^{\circ}$ 01.- El estado de conservación es malo, ya que la osamenta se encuentra fragmentada. 

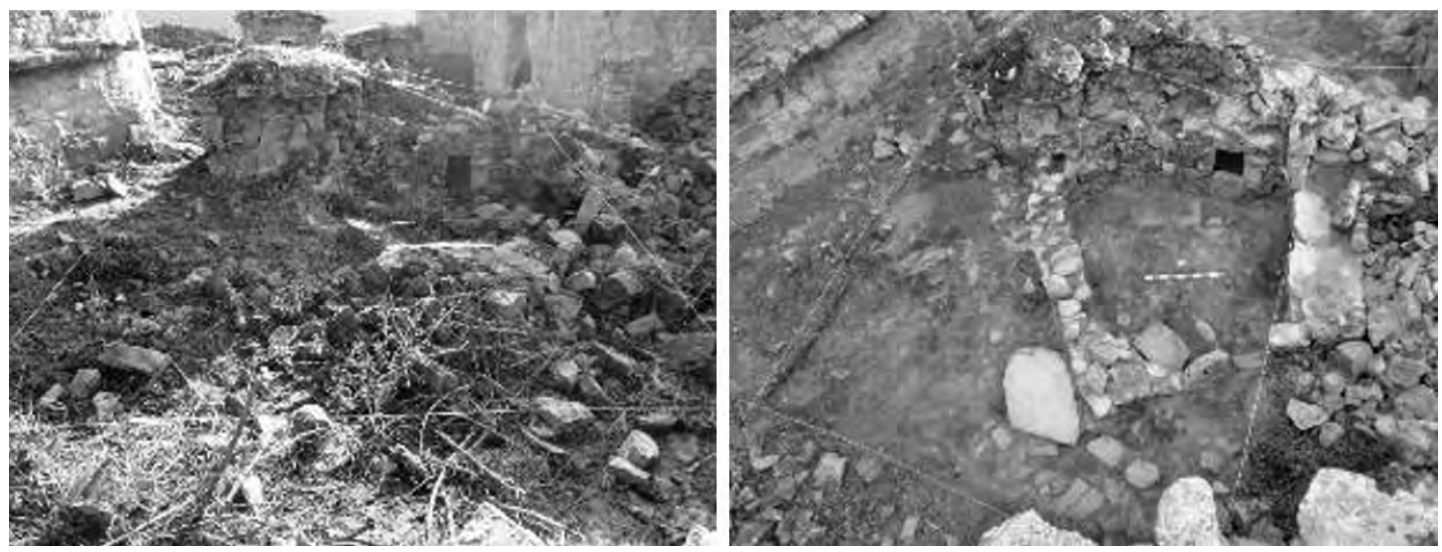

Figuras 35 y 36: A la izquierda capa superficial, a la derecha capa A. vistas panorámicas.
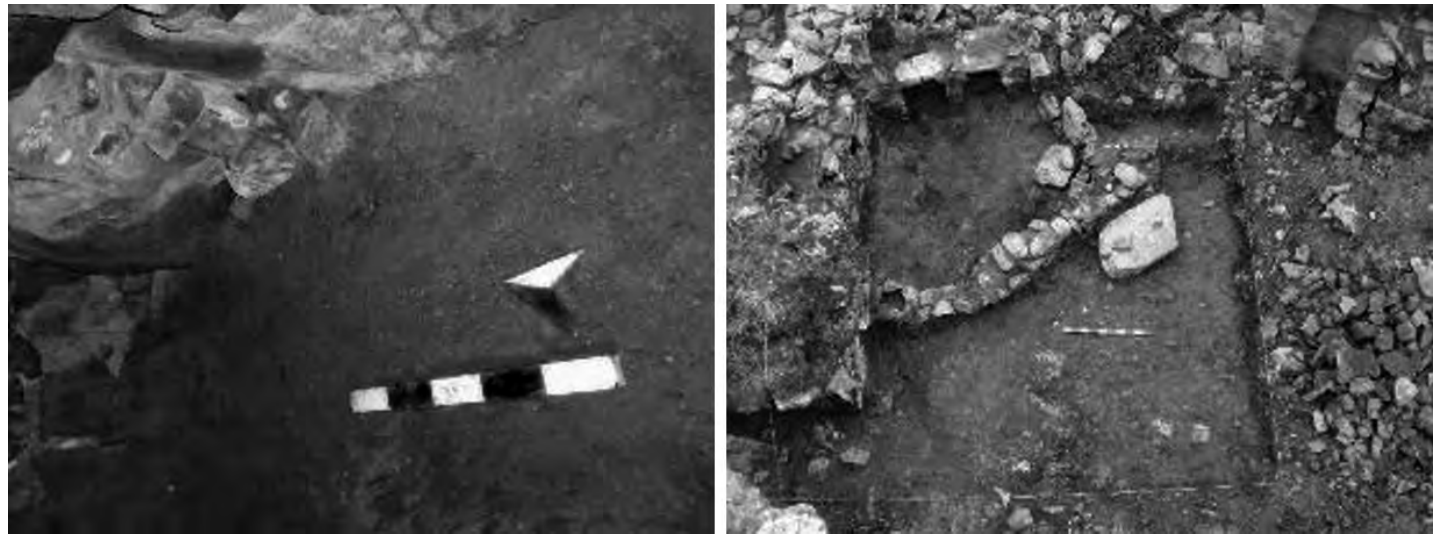

Figuras 37 y 38: A la izquierda capa B, conformada por arcilla; a la derecha capa final (roca geológica).
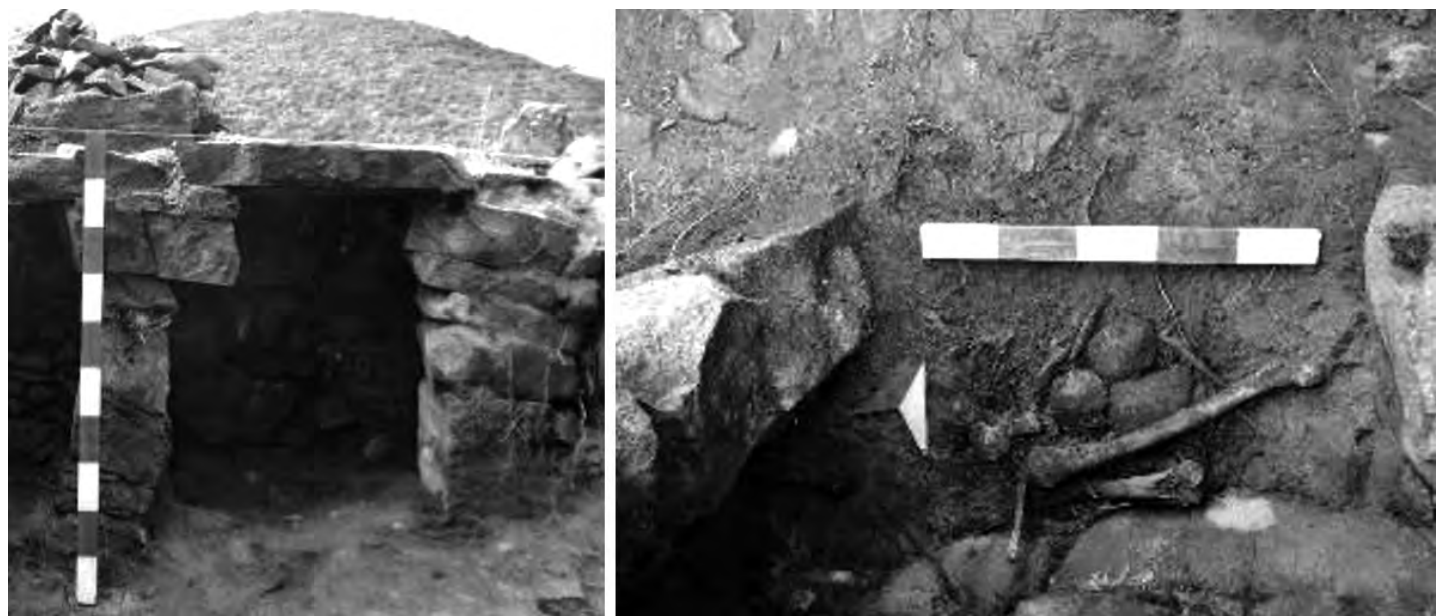

Figuras 39 y 40: A la izquierda cámara $N^{\circ} 4$, donde se halló el CF-1; a la derecha vista en detalle del contexto funerario $N^{\circ} 01$. 
Ubicación: se sitúa en el interior de la cámara $\mathrm{N}^{\circ} 04$, cubierto por la capa B. Se halla a $0.23 \mathrm{~m}$ de la superficie y a $1.08 \mathrm{~m}$ con respecto al datum.

Estructura funeraria: La estructura se caracteriza por ser una cámara funeraria que se ubica dentro del recinto $\mathrm{N}^{\circ} 01$, para efectos del registro se le ha denominado cámara $\mathrm{N}^{\circ} 04$, mide $0.90 \mathrm{~m}$ en el eje oeste - este, $0.37 \mathrm{~m}$ en el eje sur - norte y $0.80 \mathrm{~m}$ de alto.

Individuo: se trata de un contexto secundario, ya que la osamenta está desarticulada e incompleta. El individuo es de sexo masculino, adulto mayor, ya que los alveolos donde se insertan los premolares y molares se encuentran sellados; la posición y la orientación no se pueden determinar ya que se encontró desarticulado. Las dimensiones del contexto son: $0.66 \mathrm{~m}$ en el eje oeste - este y $0.32 \mathrm{~m}$ en el eje sur - norte.

Asociaciones: asociado a este individuo se encontró una preforma de piruro la cual tiene $10 \mathrm{~cm}$ de diámetro y $0.6 \mathrm{~cm}$ de espesor.

\section{5.- UNIDAD 15}

La unidad $\mathrm{N}^{\circ} 15$ se encuentra ubicada dentro del Sector 'A', emplazada dentro de un recinto de planta rectangular y presenta un desnivel poco pronunciado hacia su lado oeste. Como referencia podemos mencionar que dicha unidad se sitúa al lado este del kullpi $\mathrm{N}^{\circ} 20$. La unidad $\mathrm{N}^{\circ} 15$ presenta las siguientes coordenadas: $8747446 \mathrm{~N}-0303009$ E y se sitúa a una altura de 3525 m.s.n.m. Se encuentra orientada de noreste a suroeste y mide $4 \mathrm{~m}$ de largo por $4 \mathrm{~m}$ de ancho; la profundidad máxima de la excavación es de $1.11 \mathrm{~m}$.

El recinto es de planta irregular, cuyo material constructivo es en base a piedras canteadas, pachillas, unidas con argamasa de arcilla. Tiene $5 \mathrm{~m}$ (norte-sur), 4.50m (este -oeste) y una altura aproximada de $2.30 \mathrm{~m}$. Presenta 7 muros que conforman el exterior e interior del recinto, el grosor de los muros varía de $0.50 \mathrm{~m}$ a $0.70 \mathrm{~m}$ distribuidos de norte a sur y de este a oeste, presenta una planta rectangular. Presenta 6 vanos de acceso, el primero sirve como único ingreso al recinto y está ubicado en el muro $\mathrm{N}^{\circ} 1$, los otros 5 vanos sirven para acceder a cámaras internas. La altura de los vanos es aproximadamente de $0.60 \mathrm{~m}$, con un ancho de $0.50 \mathrm{~m}$ y un grosor de $0.60 \mathrm{~m}$. Los paramentos presentan nichos de diferentes tamaños $(0.20 \mathrm{~m}$ de ancho, $0.15 \mathrm{~m}$ alto y una profundidad de $0.15 \mathrm{~m})$, de forma rectangular y cuadrangular. Esta edificación presenta dos momentos constructivos. El primero representa a una construcción local de tipo Kullpi (Atavillos). El segundo momento se aprecia en la inclusión de elementos arquitectónicos inca, sin dejar la técnica constructiva local. Esta segunda intervención arquitectónica se aprecia en la cubierta a dos aguas, teniendo en cuenta que su cubierta original es mediante lajas apiladas unas sobre otras, cubiertas por una torta de arcilla. Esta innovación de la cubierta a dos aguas se dio tras la llegada de los incas a la cuenca. El espacio interno del edificio tiene $3.50 \mathrm{~m}$ de largo por $2.50 \mathrm{~m}$ de ancho. Este espacio además está dividido por una plataforma que va desde el vano de acceso principal hasta la mitad del recinto. Existen 6 cámaras, cuyos vanos de acceso se encuentran en los paramentos. Estas cámaras en algunos casos albergan osamentas desarticuladas.

La capa superficial de origen natural, cubre a la capa A, la cual fue definida como el derrumbe de los muros que constituyen el Recinto $\mathrm{N}^{\circ}$ 01. La capa A cubre a la capa C, esta última capa fue depositada sobre la capa $\mathrm{E}$ o Apisonado $\mathrm{N}^{\circ} 01$. En el extremo suroeste del Recinto $\mathrm{N}^{\circ} 01$ al retirar la capa $\mathrm{A}$ se definió la Capa B; la cual no fue excavada, por ello no se logró definir la relación estratigráfica de dicha capa y la capa C. La capa D fue registrada dentro de la Estructura $\mathrm{N}^{\circ}$ 01, la cual se ubica en la parte central y hacia el lado oeste del Recinto $\mathrm{N}^{\circ} 01$. Dicha capa contenía al Contexto Funerario $\mathrm{N}^{\circ} 01$. Finalmente, se identificó la capa F la cual se ubica dentro de la Estructura Subterránea $N^{\circ} 01$. Dicha estructura se sitúa hacia el lado oeste de la Plataforma $\mathrm{N}^{\circ} 01$. 


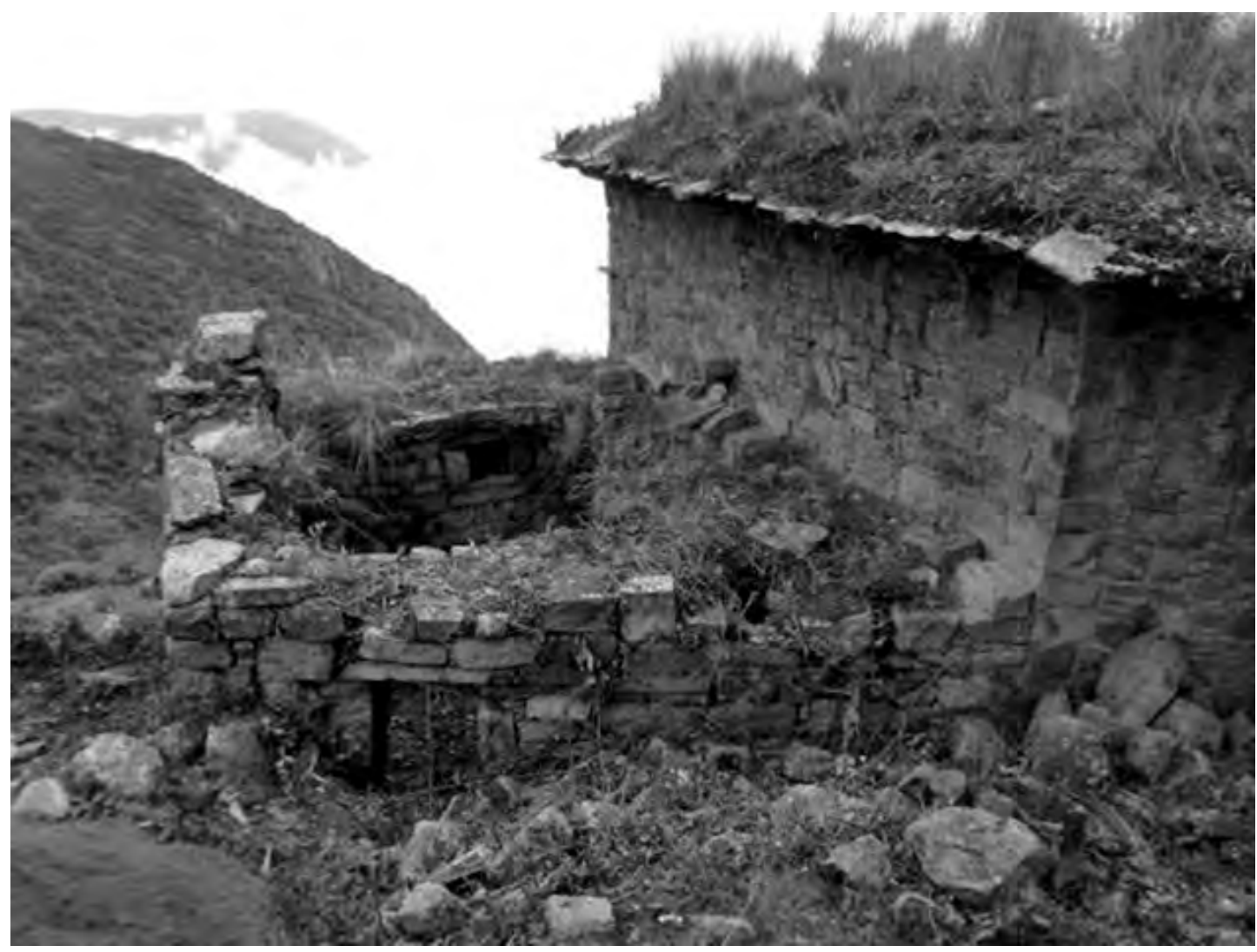

Figura 41: Vista del área de excavación de la unidad 15.

El Recinto $\mathrm{N}^{\circ} 01$ fue edificado sobre un terreno irregular en el que destaca la presencia de la roca madre ubicada hacia el lado noreste. Para utilizar el mayor espacio posible; se construyó la Plataforma $\mathrm{N}^{\circ} 01$, conformado por el muro $\mathrm{N}^{\circ} 10$, con ello se logró nivelar la superficie de la roca madre y a la vez facilitar el ingreso al Recinto $\mathrm{N}^{\circ} 02$ (ubicado en el extremo noroeste de la unidad). Con ello se generó un espacio a desnivel (situado al suroeste de la Plataforma $\mathrm{N}^{\circ} 01$ ), para acceder a dicha área se colocó un voladizo en la parte central de la Plataforma $N^{\circ} 01$. Este espacio a desnivel es de suma importancia ya que permite el ingreso a los tres niveles de cámaras (situadas al suroeste de la unidad). El nivel de uso o nivel de superficie del Recinto $\mathrm{N}^{\circ} 01$ fue la capa E o Apisonado $\mathrm{N}^{\circ} 01$.

Sobre esta capa se identificó la capa $\mathrm{C}$ de color negro compuesta por tierra arcillosa y material cultural quemado, en algunos casos se observó restos óseos cremados (mayor combustión y muestran un color plomo claro o blanco). Las características de esta capa nos indican que estamos frente a un evento de clausura de este espacio o Recinto $\mathrm{N}^{\circ} 01$, dicho evento está relacionado a la quema y el depósito de elementos culturales: fragmentaria cerámica (en su mayoría de pasta fina), restos óseos y artefactos líticos.

En cuanto a los hallazgos se tiene: en la capa superficial H-1 (artefacto lítico), H-2 (2 proyectiles). En la capa A, se tiene el H-3 (chancador), H-4 (artefacto musical de osamenta animal). La capa C, presenta los H-5 (chancador), H-6 (proyectil), H-7 (un proyectil y un chancador), H-8 (piruro), H-9 (artefacto textil de osamenta animal), $\mathrm{H}-10$ (un proyectil y un piruro), $\mathrm{H}-11$ (piruro), $\mathrm{H}-12$ (un artefacto 
textil y un dije de metal), H-13 (objeto lítico). En la capa D, se tiene el CF-1. En la capa F, se tiene un depósito subterráneo de basura arqueológica.

Contexto funerario $\mathrm{N}^{\circ} 1$.- El contexto funerario se ubica dentro de la estructura $\mathrm{N}^{\circ} 01$, la cual se ubica en el lado oeste del Recinto $\mathrm{N}^{\circ} 01$.

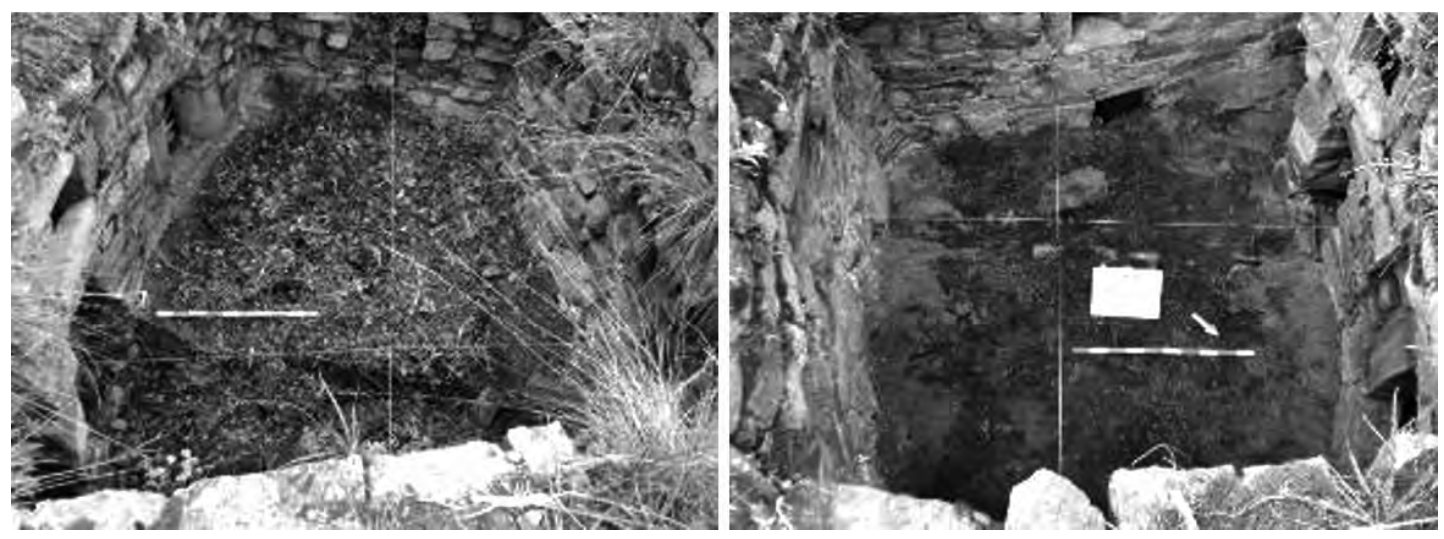

Figuras 42 y 43: A la izquierda capa superficial, a la derecha capa A. recinto $N^{\circ} 1$.
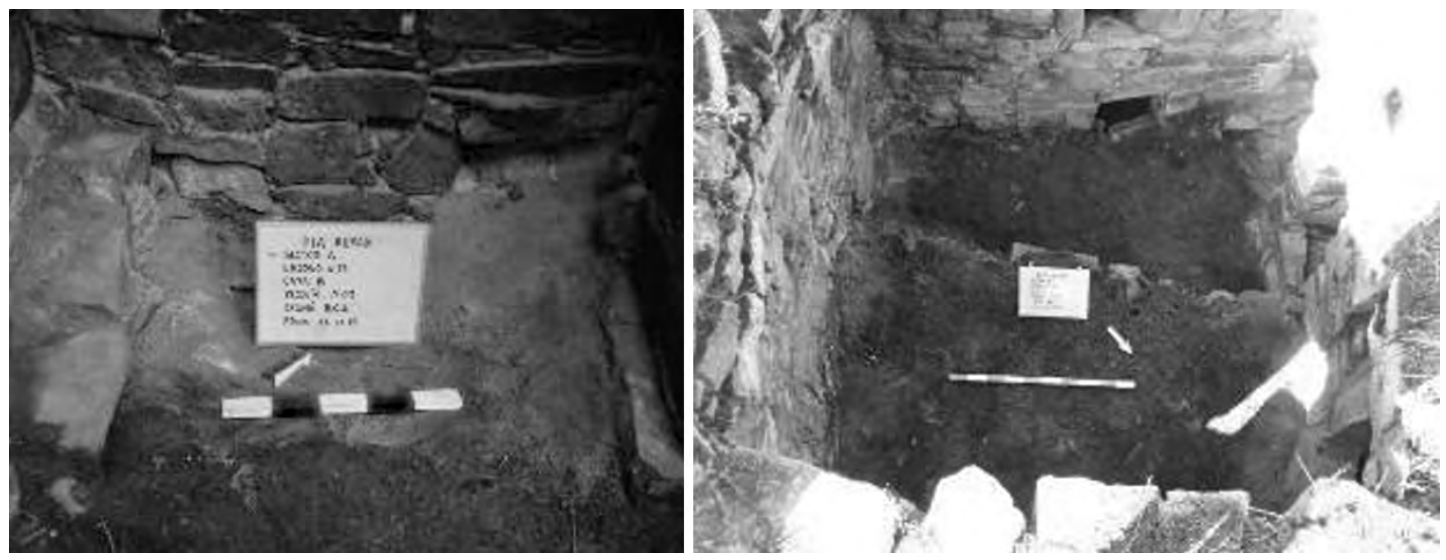

Figuras 44 y 45: A la izquierda capa B, en el interior de una cámara. A la derecha la capa C, recinto $N^{\circ} 1$.
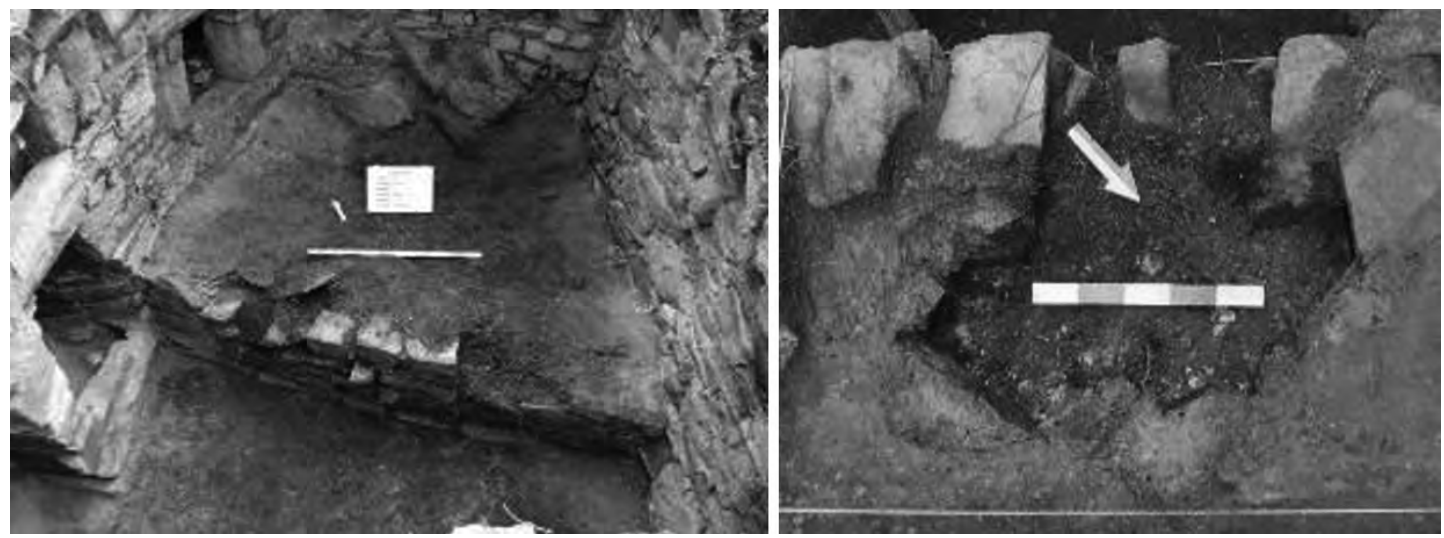

Figuras 46 y 47: A la izquierda capa E, parte inferior. A la derecha capa F, depósito de basura arqueológica. 
Estructura funeraria: estas osamentas se hallaron depositadas sobre el lecho de tierra de color beige, en el interior de la estructura №1, la cual corresponde a una cámara funeraria. Esta cámara tiene $0.60 \mathrm{~m}$ de largo por $0.60 \mathrm{~m}$ de ancho y una altura de $0.80 \mathrm{~m}$. Presenta un vano de acceso, por el cual se puede ingresar desde el recinto $\mathrm{N}^{\circ} 1$. Las piedras del interior de la cámara funeraria presentan coloración negruzca, posiblemente debido a la filtración de agua.

Individuo: El área de dispersión ósea se orienta de suroeste a noreste y conforma un área de planta irregular de $0.65 \mathrm{~m}$ de largo por $0.52 \mathrm{~m}$ de ancho, el tipo de entierro es secundario y las osamentas están desarticuladas. Debido a que no se halló el cráneo, la pelvis ni el sacro, no se pudo identificar su edad ni sexo en campo. Está constituido por un conglomerado de restos óseos (entre ellos huesos largos y mandíbulas). El estado de conservación es malo, ya que se encuentran de color blanco por la exposición al sol directamente, además de encontrarse muy fragmentado.

Asociaciones: se halló fragmentos de cerámica.
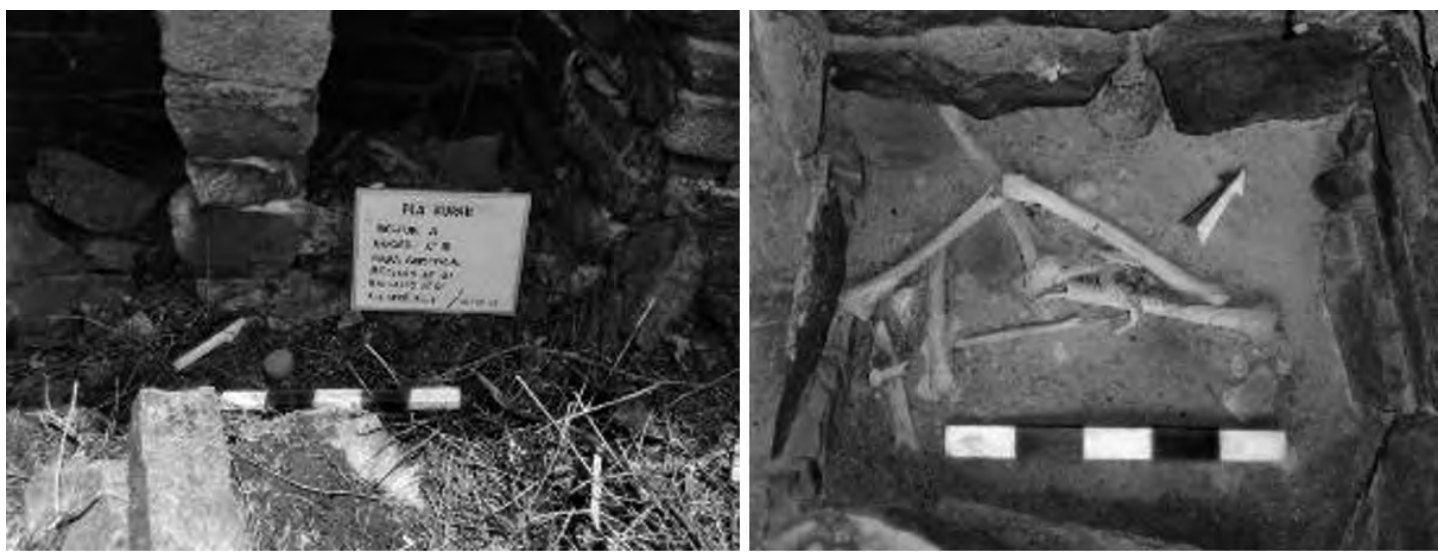

Figuras 48 y 49: A la izquierda cámara funeraria que contiene al CF-1; a la derecha contexto funerario $N^{\circ} 1$.

\section{VI.- ANÁLISIS ARQUITECTÓNICO}

Entre las edificaciones identificadas destacan los edificios tipo chullpa y tipo kullpi, que son los más densos en el sitio en todos sus sectores.

\section{A.- Arquitectura tipo Kullpi:}

Los Kullpis son edificios característicos de las cuencas altas de los ríos Chancay y Chillón. Su presencia está relacionada con las ocupaciones Atavillos (tardíos). En anteriores trabajos (van Dalen 2007; 2014, Villar 1982) se ha definido las características de estos Kullpis similares y comunes, las cuales analizaremos a continuación:

Materiales Constructivos: Los materiales constructivos utilizados fueron la piedra, la cual era obtenida de canteras ubicadas en los cerros circundantes. Las piedras eran labradas, en formas adoquinadas o rectangulares; mientras que otras eran labradas de forma alargada, elaborando lajas para las cubiertas. Además, se utilizó tierra, la cual tiene en algunos casos composición arcillosa. Se utilizaron pachillas entre las piedras.

Técnicas Constructivas: Como señalamos las piedras eran labradas o talladas y eran mampuestas una sobre otra en los muros, de tal manera que las caras planas eran colocadas en el paramento interno o externo y las caras irregulares iban hacia la argamasa, para unirse con las otras piedras. 
Las piedras se colocaban en hiladas horizontales de manera irregular, a su vez superpuestas entre sí. Para dar la forma de los elementos se adecuaba a los tamaños y formas de las piedras. Así para la techumbre, se utilizaba las piedras alajadas, de tal manera que una parte quedaba incrustada en el muro y la otra quedaba como saliente, parte que servía como soporte para colocar otra piedra encima, e ir cerrando el espacio. La argamasa era una preparación de arcilla, con incrustaciones de piedras pequeñas, paja y cerámica fragmentada. Entre las piedras grandes se colocaban pequeñas piedras (pachillas), con la finalidad de dar estabilidad, y rellenar los espacios faltantes.

Planta: La planta de los Kullpis era cuadrada o rectangular, con medidas que variaban según la importancia que estás tenían. Podían tener hasta 10 metros por lado.

Forma: la forma dependía de la planta y podía ser cuadrada o rectangular en el exterior y de falsa bóveda en el interior.

Basamentos: Para la edificación de los basamentos o cimientos se excavaba hasta llegar a la roca geológica. Aquí se iniciaba la construcción con muros gruesos, edificando sobre estas una serie de galerías, por debajo del nivel superficial normal. Este basamento se adapta al relieve.

Paramentos: Los muros podían llegar a tener hasta 5 o 6 metros de altitud, de gran solidez, de 0.60 a 0.80 metros de grosor. En los muros se podía elaborar motivos decorativos, con los mismos elementos constructivos. Las esquinas de los muros eran amarradas. Por lo general los muros externos eran rectos, pero en el caso de los internos eran curvos, con esquinas curvas. La mayoría de paramentos externos presentan una muy ligera inclinación hacia fuera.

Cubierta o Techumbre: Las techumbres de las estructuras eran en la parte interna de forma abovedada, elaborado mediante lajas consecutivas salientes, que hace que el espacio se vaya volviendo más angosto. La cubierta externa es plana, con una gruesa capa de arcilla mezclada con paja (para impermeabilizarlo) y fragmentería cerámica en la parte superior, para proteger a la edificación de las lluvias. Las lajas que forman el techo tiene como soporte a los muros mismos, y en pocos casos columnas y vigas.

Aleros o Cornisas: En varios casos los Kullpis presentan en el paramento externo, parte superior, una saliente del muro, de 0.40 metros, la cual sirve para proteger a los muros en caso de lluvias y como elemento ornamental. En otros casos es la misma techumbre la que cumple esta función.

Vanos: Los vanos, tanto de acceso principal (que es el que comunica el exterior con la cámara principal), como las de acceso interno, son de tamaño pequeño, y son de forma rectangular. La altura promedio de los vanos es de 0.50 a 0.60 metros, y un ancho variable, de hasta 0.60 metros. En algunos casos, el vano principal se encontraba en la parte inferior de un nicho rectangular o "falso pórtico" o "Huayrona". En el caso de las edificaciones del periodo Tahuantinsuyo, estas tienen forma trapezoidal, es decir son más anchas en la parte inferior y más delgadas en la parte superior. El vano principal casi siempre está orientado con el vano interno. Había también vanos de forma cuadrangular. Algunos vanos presentan bien definida la jamba, habiéndose identificado en Chíprac, vanos con doble jamba del periodo Tahuantinsuyo. El dintel está conformado por una laja que se ubica sobre los dos lados del muro, su tamaño está en relación con el ancho del vano, pero siempre es más largo que el ancho del vano. En el interior de las edificaciones se aprecian numerosas ventanas de forma cuadrangular, ubicadas a diferentes niveles, que comunican la cámara principal con las cámaras secundarias. Muchas de estas ventanas sirven también incluso como vanos.

Cámara Principal: Luego de ingresar desde el exterior por el vano principal, se aprecia una amplia cámara principal, desde donde se comunica con todas las cámaras y compartimientos internos 


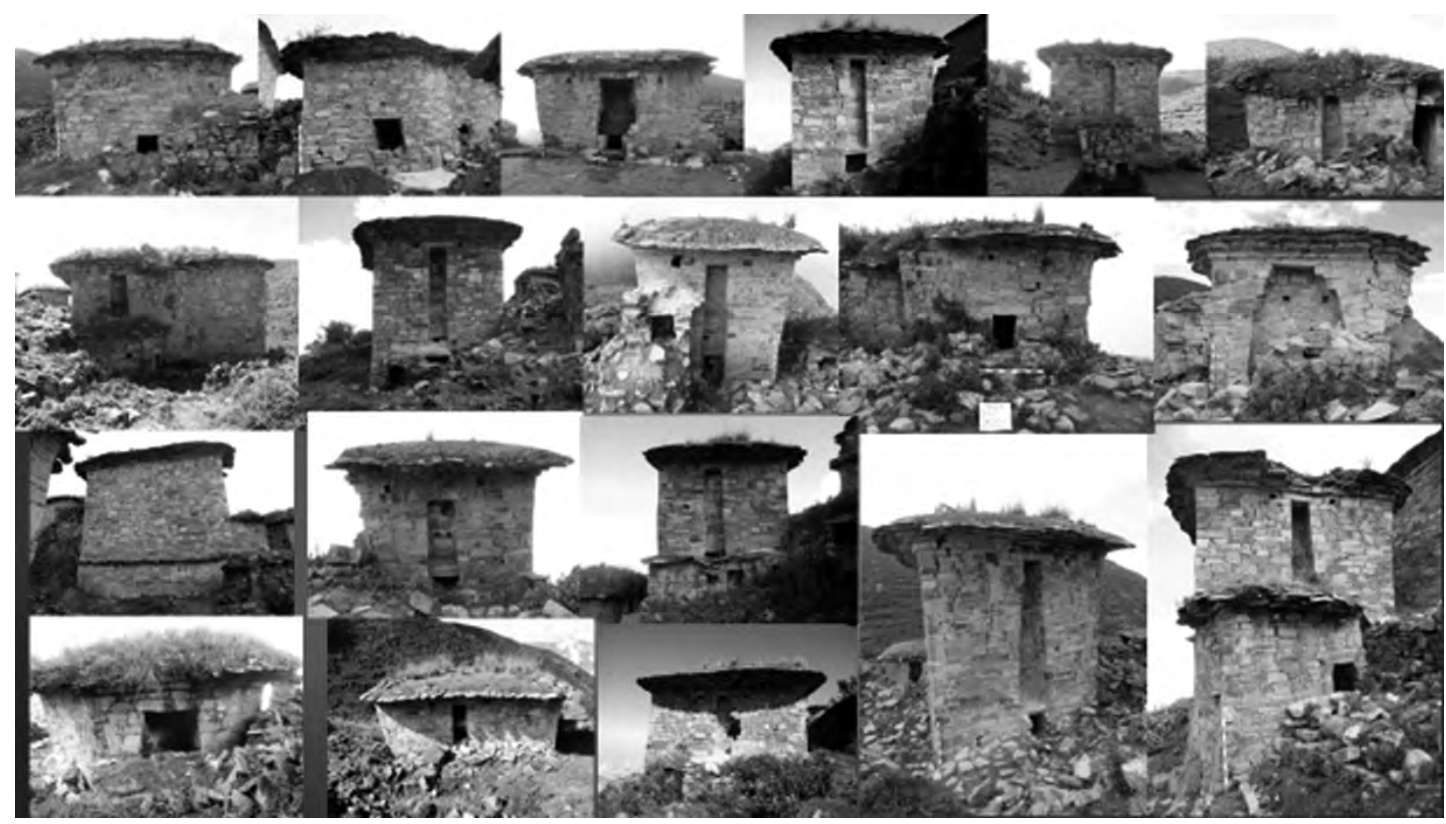

Figura 50: Vista de diferentes kullpis de Rupac, sector B.

Tiene casi la misma altura de la estructura. El techo es abovedado. Frente al vano principal se aprecia un vano secundario, que comunica con una cámara pequeña, donde se ingresa a las cámaras subterráneas, que se ubican debajo de esta cámara principal. Una persona puede estar parada en el interior de esta cámara principal. Se aprecian a diferentes alturas pequeños vanos, ventanas y ductos de ventilación que comunican con las cámaras superiores, accediéndose a estos mediante voladizos consecutivos. Algunos Kullpis tienen antes de esta cámara principal un descanso pequeño.

Cámaras y Galerías Secundarias: Como señalamos, a partir de esta cámara principal se interconectan numerosas cámaras secundarias, ubicadas hasta en siete niveles superpuestos, a veces comunicadas entre sí por galerías que rodeaban la cámara principal. Algunas cámaras cumplen función de almacenamiento de productos, ya que la temperatura interna de las estructuras regula y permite su conservación. Así en las cámaras superiores se ha identificado restos de semillas y granos de maíz. En cambio en las inferiores se depositaban entierros individuales o múltiples. También se depositaban entierros en la parte superior. La superficie de las cámaras presenta una capa de tierra producto de la acumulación de sedimentos por la realización de diferentes actividades.

Columnas: Los Kullpis presentaban columnas de forma cuadrangular y rectangular. Son más gruesas en la parte superior, por su forma trapezoidal invertida. Sirve de soporte a las cámaras superiores y a la techumbre.

Ménsulas: Son elementos conformados por salientes consecutivas escalonadas, que cumplen la función de servir como soporte estructural a la techumbre, de forma semi triangular, formando un ángulo entre el muro y el techo.

Vigas: Son refuerzos horizontales, conformado por dos o tres hileras horizontales salientes del muro, en el paramento interno, que sirve como soporte del techo.

Chimeneas o ductos de ventilación: Existen conductos verticales que salen desde la superficie misma, en una esquina de la estructura hasta la parte superior de la techumbre, comunicándose con 
el exterior por una pequeña ventana cuadrangular. Se trata de un conducto de ventilación, que en algunos casos se podía utilizar como chimenea, con fines domésticos, asociados a los fogones.

Voladizos: Son piedras alargadas que se disponen perpendicularmente al muro y se encuentran empotradas en este, mientras que la otra mitad está en el aire. Se hallan dispuestas de tal manera que una está por encima de otra a manera de escalinatas.

Decoración Muraria: La mayoría de los muros presentan cierta coloración rojiza, de origen natural, lo que se debe a que las piedras presentan una alta composición química de hierro, lo que al contacto con los diferentes agentes ambientales, provoca su oxidación, obteniendo de esta manera una coloración rojiza en la pátina de la piedra. Cabe señalar que algunas edificaciones de tipo Kullpi, presentan enlucido de arcilla y una pintura rojiza, tanto en el interior como exterior de las edificaciones. Sin embargo, en el interior de un Kullpi de Araro, se identificó un dibujo, sobre el dintel, con representaciones de escenas de caza de camélidos, en color negro. Además existe decoración en alto relieve, hecha con las mismas piedras constitutivas de la estructura arquitectónica, tanto en la fachada como en el interior del mismo. Son recurrentes la presencia de nichos agrupados o alineados en los paramentos internos de los Kullpis o en sus columnas.

\section{B.- Arquitectura tipo Chullpa:}

Las chullpas son edificaciones de función netamente funeraria. En el sitio arqueológico de Rupac, están asociados a entierros secundarios múltiples, se han podido identificar una gran cantidad de osamentas desarticuladas en el interior de estas edificaciones, por la cantidad de cráneos, huesos largos, pelvis, sacros y vértebras, se puede saber que hubo más de un individuo al interior. La edificación tipo chullpa, presenta la misma técnica constructiva que las edificaciones de tipo kullpi, es decir sus paramentos están elaborados en base a piedras labradas, unidas con argamasa de arcilla, en los espacios vacíos entre la unión de la roca y la argamasa se colocaban piedrecillas a modo de pachillas. Las hileras del paramento son irregulares, trabajadas en el paramentos exterior y toscas hacia el paramento interior, estas edificaciones tienen una altura promedio de $1 \mathrm{~m}$ de largo y entre $0.80 \mathrm{~m}$ y $1.20 \mathrm{~m}$ de ancho, mientras que el grosor de los muros varían entre $0.40 \mathrm{~m}$ y $0.60 \mathrm{~m}$. El vano de acceso se ubica siempre en la parte central del frontis del paramento, tiene en promedio $0.40 \mathrm{~m}$ de ancho, $0.50 \mathrm{~m}$ de altura y $0.40 \mathrm{~m}$ de grosor, estos presentan dintel, jambas y en algunos casos particulares, umbrales. En la parte superior y sobre el dintel se puede apreciar pequeños nichos cuadrangulares de $0.15 \mathrm{~m}$ de ancho, $0.15 \mathrm{~m}$ de altura y un espesor de $0.10 \mathrm{~m}$, estos nichos están alineados horizontalmente, apareciendo de a dos. La parte interna de las chullpas tiene una cámara rectangular o cuadrangular con esquinas curvas, donde se depositan las osamentas. La cubierta de la chullpa es cónico-trunca, elaborado a partir de la superposición de lajas de piedras consecutivas, estas a su vez están cubiertas por una torta de arcilla con inclusiones de material arqueológico (fragmentos de cerámica) que permiten la impermeabilidad del edificio, evitando filtraciones y haciendo que el desfogue del agua se dé por las lajas que sobresalen $0.40 \mathrm{~m}$ de la cornisa y paramentos exteriores. Para el sitio arqueológico de Rupac, específicamente se ha podido apreciar en base a los estudios que existe una distribución de las chullpas, asociadas a diferentes lugares y edificaciones, es por ello que se ha tratado de clasificar esta edificación de acuerdo a su ubicación independiente o asociado a otras edificaciones colindantes. Al parecer estas edificaciones cumplían una función vinculada a diferentes escenarios rituales, siempre ligados a la muerte y a cobijar a los entierros secundarios.

- Chullpas adosadas: se ubican en el sector B, del sitio arqueológico. Estas chullpas forman cuerpo alargados de hasta $9 \mathrm{~m}$. Estas edificaciones están unidas, ya sea porque sus paramentos están entrelazados o por estar adosados unos a otros; sin embrago se puede seccionar cada uno de 
manera independiente, ya que presentan vanos independientes y en el interior las cámaras también son independientes y no tienen conexiones internas. En Rupac se puede ver en el sector C la asociación de 7 chullpas alrededor de un patio. En el interior de las cámaras aún se puede apreciar osamenta humana (cráneos, huesos largos, vertebras, etc). Este sector habría estado asociado con un área pública de reunión para el culto a sus ancestros.

- Chullpas independientes: estas edificaciones normalmente aparecen independientes, como complemento de las demás edificaciones, algunas veces próximas a los kullpis, y otras veces asociadas a patios. Sin embargo todavía no se ha podido determinar el por qué se ubican de esta manera.

- Chullpas de dos niveles: estas edificaciones están construidas una sobre otra, se trata de dos cuerpos solidos construidos en dos niveles, próximos siempre a los kullpis.

- Chullpas asociadas a kullpis: estas edificaciones están asociadas a la clausura del vano de acceso de los kullpis, es decir se adosó esta edificación al vano de ingreso, en algunos casos clausurándolo y en otros manteniendo su entrada, sin embargo el acceso queda restringido, ya que se tiene que ingresar primero a la chullpa y después recién al kullpi. Sin embargo en el interior de estas chullpas también se halló osamenta humana; al parecer su función, además de ser funeraria era de restringir el acceso a la edificación principal. No se sabe si estas chullpas fueron edificadas en el mismo momento del kullpi, o quizá posteriormente para evitar los saqueos de los Incas o tal vez de los españoles.

Es preciso señalar que las chullpas de Rupac, presentan un enlucido de barro, sobre el cual se aplicó pintura de color blanco. Algunas chullpas presentan nichos pequeños cuadrangulares en los paramentos.

\section{C.- Arquitectura tipo Inca local:}

A la llegada de los Incas a Rupac, se mandó a construir edificaciones, las cuales sobresalen por sus elementos arquitectónicos propios de edificaciones incas, aunque a menor escala. Estas edificaciones fueron construidas con técnica y material local; sin embargo, se adicionó elementos como: vanos trapezoidales, cubierta a dos vertientes, los espacios internos son más amplios; adicionalmente se halló fragmentos de cerámica de tipo Inca local e inca regional en las excavaciones, lo que demuestra la asociación existente entre edificio y estrato cultural de ocupación propiamente dicho. Una de las peculiaridades de esta construcción es el aprovechamiento de construcciones locales, para, sobre estos cimientos: construir, modificar, adicionar e incluir elementos arquitectónicos incas. Después del reconocimiento y prospección se ha podido identificar dos tipos de edificios con estas características.

- "Cabildo"5: se trata de un edificio de planta irregular alargada que cuenta con 6 vanos trapezoidales, estos vanos presentan dinteles rectangulares, en algunos casos muy próximos a clavos de piedra. Tiene un largo máximo de $13.15 \mathrm{~m}$, un ancho máximo de $3.80 \mathrm{~m}$ y una altura que oscila entre $1.90 \mathrm{~m}$ y $4.30 \mathrm{~m}$. Entre sus elementos arquitectónicos podemos mencionar la presencia de tres muros de forma irregular (semi-rectangulares), cuyo grosor varía entre $0.40 \mathrm{~m}$ y $0.60 \mathrm{~m}$ de ancho. El paramento interno contiene 29 nichos de forma rectangular y cuadrangular, estos nichos contienen en su interior, osamenta humana (cráneos y huesos largos), así como objetos rituales contemporáneos (coca, cigarro, caña). En el paramento externo también se identificó 
nichos. El tipo de mampostería es ordinaria de hileras irregulares, con argamasa de arcilla y pachillas, sus esquinas son adosadas y en otros casos concertadas. Su cubierta es de lajas de piedras superpuestas unas sobre otras para crear la caída apropiada del agua en tiempos lluviosos, con una torta de arcilla sobre esta, permitiendo que en el edifico no se filtre el agua. Su cimentación es continua compuesta por materiales ciclópeos y conglomerado. El piso del edifico es de arcilla, presenta cortes por efectos de huaqueo. El edifico no presenta decoración. El estado de conservación es regular, presenta grafitis modernos, derrumbe hacia el lado sur del paramento 3, filtraciones por pérdida de argamasa de arcilla que cubría las lajas de piedra.

- Kallankas: se identificó 3 edificaciones, de las cuales solo se excavó dos. Estas edificaciones se caracterizan por incluir elementos arquitectónicos incas, a manera de reconstrucciones, remodelaciones e inclusiones, sobre edificios Atavillos, como: la cubierta a dos vertientes, vanos trapezoidales, la cámara principal de un aspecto abovedado es cambiando por un espacio más amplio con paramentos rectos, la planta de la edificación de esquinas curvas (kullpis) pasa a ser de esquinas ortogonales, entre otros. Sobre todo la funcionalidad del edificio cambia, sin embargo las cámara funerarias subterráneas con entierros preincas (Atavillos) se hallaron intactas, solo se reocupó la cámara principal y las cámaras de los niveles superiores.

\section{D.- Espacios abiertos:}

Los espacios abiertos se pueden dar de dos tipos, ambos de carácter público, para congregación de la población, ya sea de uso religioso o doméstico.

Plaza: denominado como sector "C", es un espacio abierto, público y ceremonial. Al parecer habría servido como centro de congregación de la población y a su vez como área ritual. Es preciso señalar que se identificó una cúpula en el centro de la plaza.

Patios: son espacios abiertos y a la vez rodeados por edificaciones tipo Kullpi y chullpas. Estos patios agrupan edificaciones a su alrededor, el vano de ingreso de las edificaciones está orientado siempre al centro del patio. Para poder conectar estos patios con otros, se puede acceder mediante pasadizos. En comparación con la plaza, los patios son espacios más reducidos, donde se desarrollaban actividades domésticas y reuniones del grupo familiar alrededor de esta. En las excavaciones de los patios se identificó material de basura arqueológica, como restos de material botánico, fragmentos de cerámica, desperdicios de huesos de roedores, aves y cérvidos, los cuales eran consumidos en el quehacer cotidiano.

\section{VII.- ANÁlisis DEL MATERIAL OSEO HUMANO PROCEDENTES DE LOS CONTEXTOS FUNERARIOS}

\section{1.- Contexto Funerario 1: Unidad: 1, Capa B, recinto 2.}

Niña de 7 años de edad. Cráneo fragmentado en 7 partes, 1 mandíbula completa, 14 dientes sueltos (4 incisivos, 5 molares, 3 premolares, 2, caminos), hay otro fragmentos de mandíbula de otro individuo infante, 2 clavículas, 3 vértebras cervicales, 1 escápula izquierda, 2 costillas, 2 pelvis, 2 húmeros sólo diáfisis, 2 fémures, 2 tibias, 2 perones, 2 calcáneos, 2 astrágalos, 1 rótula, 2 radios, 2 cúbitos y 2 húmeros.

\section{2.- Restos humanos de la Unidad 3}

En la capa superficial de la unidad 3 se hallaron los siguientes restos óseos humanos: 5 fémures (4 derechos y 1 izquierdo, NMI=4), al parecer de mujeres, color blanquecino, rajados, cuarteados e 
insolados. Además se encontró 1 fémur derecho de $0.38 \mathrm{~m}$ de largo y de sexo femenino, 2 tibias derechas, blanquecinas y rajadas, erosionadas con destrucción en las epífisis proximales por factores bioestratinómicos, 1 tibia derecha femenino de $0.32 \mathrm{~m}$ y robusto, con Hiper Vasculación (HV) en las articulaciones coxo-femoral y las rodillas. Esta última persona andaba o corría mucho.

En la capa A se hallaron también otros huesos humanos: 1 temporal izquierdo de masculino joven, porción petrosa de la apófisis mastoides, agujero del conducto auditivo con ligeras espículas óseas y arco zigomático no fusionado.

Posteriormente en la capa B se halló el Contexto Funerario 1, hallándose los restos de un niño: 11 vértebras torácicas y lumbares de un niño de $4-5$ años de edad, 1 clavícula completa izquierda, 12 costillas, 2 fragmentos de pelvis (íleon), 1 sacro ( $1^{\circ}$ sacral) no fusionado, 1 escápula izquierda completa no fusionada, 2 isquiones no fusionado; 2 arcos vertebrales, 1 esternón (margo o manubrio); 1 húmero derecho (diáfisis sin epífisis), 2 cúbitos, 2 radios, 2 fémures ( 5 fragmentos de estas piezas), 2 tibias y 2 peronés, incluyen sus epífisis proximales no fusionados, 14 metapodios y falanges completas; 2 astrágalos y 2 calcáneos.

\section{3.- Restos humanos de la Unidad 6}

Como ya señaló líneas arriba, en la capa A se encontró el Contexto Funerario 1. En este contexto hay los restos de por lo menos 2 individuos: El primero de una mujer de 30 años de edad y el otro de una niña. Los restos óseos recuperados consisten en: 20 fragmentos del cráneo masculino adulto con modelación cefálica del tipo semi-horizontal, típico de los Atavillos, posee 3 huellas de golpes de puma cerca de la sutura lambdática, de origen serrano por los surcos profundos de las arterias emisarias meníngeas medias, hay 2 dientes desgastados y con hipoplasia del esmalte dentario, mujer que chacchaba coca. Además hay 8 costillas, fragmentadas post-mortem, 2 costillas exhiben áreas rugosas entre las facetas costales, indicando gran esfuerzo o practicaba algún deporte con fuerte impacto corporal; 3 vértebras lumbares fragmentadas y ligeramente porosas, 1 escapula derecha, 2 falanges completas de la mano del dedo medio, 8 fragmentos de pelvis, erosionados, 1 húmero derecho de $29 \mathrm{~cm}$ de largo, 1 cúbito izquierdo completo de $25 \mathrm{~cm}, 1$ radio completo de $23.6 \mathrm{~cm}$ derecho, 2 fémures izquierdo y derecho fracturados en la epífisis proximal, tiene HV en las rodillas y en la articulación coxo-femoral, 1 tibia fragmentada y 2 diáfisis fragmentados de peronés. Por su parte la niña presentaba: 1 mandíbula casi completa con dientes "in situ" de 3-4 años de edad, (C5) 1 calcáneo derecho fracturado. En asociación a estos restos humanos se halló los restos de un camélido: 1 vértebra cervical tierna de tui 10-12 meses de edad, 1 escápula completa izquierda de alpaca adulta, que constituyen ofrendas animales depositadas para acompañar al entierro.

En la misma capa A y fuera del contexto funerario 1 se recuperó sin un contexto definido y solo al interior de la capa: 2 fragmentos de frontal de cráneo de origen serrano (sinus frontalis amplio), 1 vértebra lumbar con ligero labiamiento o "lipping" en el cuerpo vertebral, 1 sacro fracturado con raíces (la fracturas son post-mortem) de adulto, 1 pelvis (íleon) de adulto fracturado, 2 tibias (1 adulto y 1 tierno con HV en la epífisis proximal de la tibia adulta), 2 metacarpianos adultos completos.

Por su parte el contexto funerario 2 identificado en la capa $\mathrm{F}$ está conformado por los siguientes restos óseos: 1 cráneo femenino adulto, pastora, de más de 50 años de edad con modelación cefálica semi-horizontal mujer robusta, dientes desgastados, pérdida de molares, chacchaba coca, con alveolos dentarios reducidos, suturas craneanas con sinostosis, arcos zigomáticos fino; espina nasal poco elevada y fina, dientes incisivos y premolares abiertos, indicador de elevado consumo de carne de camélido. Se recuperó también los restos de otro individuo: individuo femenino de 10-12 años de edad, dientes apiñados, el canino sobre el premolar izquierdo superior. También posee modelación 
cefálica semi-horizontal; suturas abiertas, huesos maxilares, temporales y el occipital están sueltos no osificados, presenta surcos profundos para las arterias emisarias meníngeas medias (parietales), asociado a una vertebral.

Por su parte en el recinto 2, capa F, se recuperó restos óseos de varios individuos, disturbados y mezclados por acción del huaqueo. Estos restos estaban conformados por: ausencia del cráneo (post-mortem), 2 mandíbulas: 1 completa de adulto femenino de 40 años de edad y otra de joven, 9 dientes adultos femenino; 42 costillas fragmentadas de adultos, 2 vértebras ( 1 atlas y 1 vértebra lumbar adulto), pelvis de 2 individuos (uno femenino adulto de 40 años de edad y otro de femenino de 16 - 14 años de edad), 4 sacros de 3 mujeres (2 adultos y 1 niña de 12 a 14 años), 2 escápulas (1 derecho) de niña de 12 - 14 años, 3 esternón de bebé de 1 - 2 años de edad, 6 húmeros, 4 radios, 4 cúbitos, 17 falanges y metapodios, 1 clavícula completa de mujer adulta robusta, 4 fémures de niña completa, 1 rótula de niña de $3-4$ años de edad, 7 tibias (4 completas de adultos) con HV en la epífisis proximal, 2 peronés fragmentados de jóvenes, 1 carpiano y 1 tarsiano completo de niña, 3 calcáneos completos: 2 izquierdo y 1 derecho (de 1 adulto y 2 niñas), 2 astrágalos completos de niño: izquierdo y derecho.
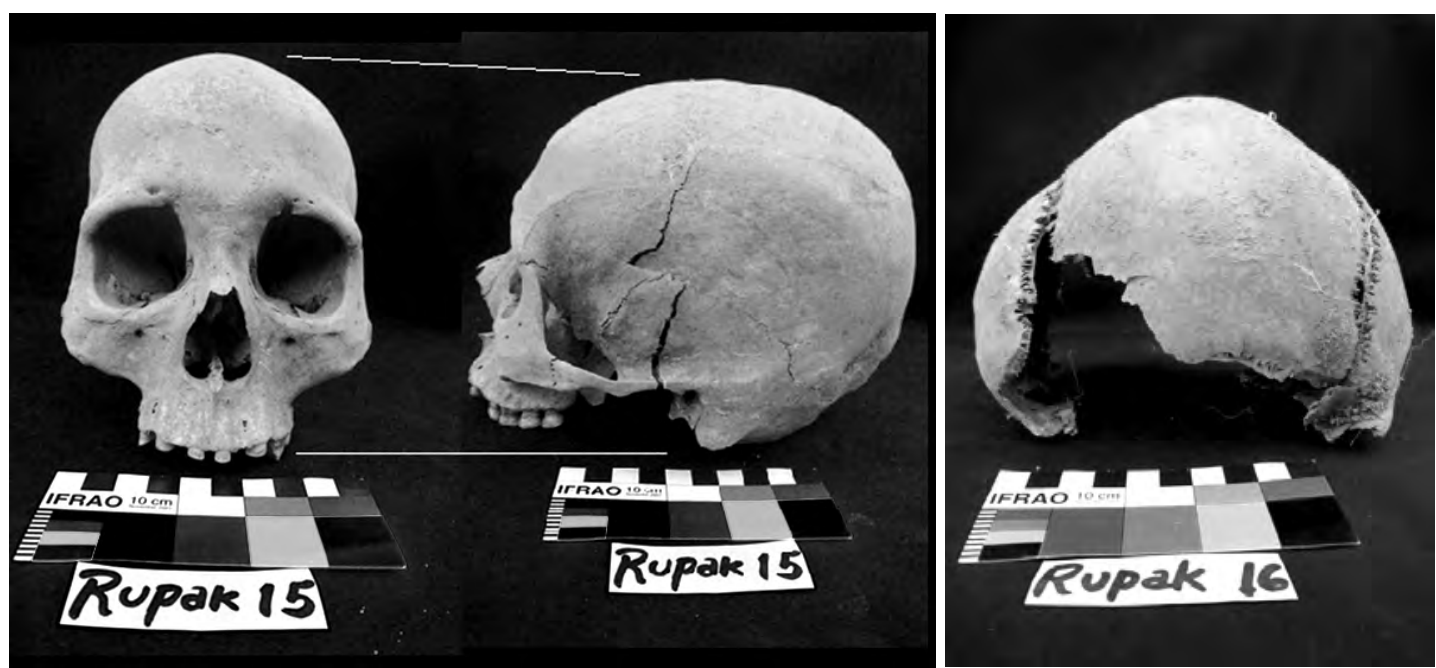

Figuras 51 y 52 (izquierda y centro): Individuo 1 (contexto funerario 2). Femenino robusta, pastora de más de 50 años de edad con modelación cefálica semi-horizontal (Atavillos bajo). Figura 53 (Derecha): Individuo 2 (contexto funerario 2). Cráneo femenino de niña de 10-12 años de edad con modelación cefálica semi-horizontal.

\section{4.- Restos humanos de la Unidad 14}

En la capa superficial se recuperó restos descontextualizados humanos: 1 pelvis y 1 astrágalo adulto fragmentados y erosionados por humedad, con muchas raíces de plantas y capa de cal. En la capa B, cámara 4, se halló el Contexto Funerario 1 de un individuo masculino, adulto de 30-35 años de edad, con completo desgaste dentario, pérdida y obliteración de alveolos de molares con fracturas per-mortem en los ángulos mandibulares, fractura per-mortem en el frontal por fuerte golpe de roca. Es un individuo serrano por la presencia de surcos profundos para la arterias meníngeas medias en los temporales y chacchaba bastante coca. Asociado a una cerámica negra utilitaria en forma circular de $5.9 \mathrm{~cm}$ de diámetro que corresponde a la parte de una olla (preforma de piruro). Se recuperó 2 fragmentos de mandíbula, 3 fragmentos de cráneo, 14 costillas erosionadas, 2 clavículas (izquierda y derecha muy erosionado con capa de cal), 9 vértebras cervical, torácicas y lumbares, 1 pelvis izquierda casi completa erosionada, 2 escápulas erosionadas por humedad y barro, 1 esternón muy erosionado, 
cuerpo esternal, ausencia del margo o manubrio y miembros superiores ( 2 húmeros, 2 radios, 2 cúbitos, todos fragmentados). Miembros inferiores: 2 fémures, 2 tibias y 2 peronés. El peroné izquierdo tuvo una severa infección por trauma que afecta la parte de diáfisis con intensa rugosidad. Fémur derecho (masculino de $39 \mathrm{~cm}$ ), tibia izquierdo (masculino de $32 \mathrm{~cm}$ ), cúbito izquierdo (masculino de $22.3 \mathrm{~cm}$ ), radio derecho (masculino de $20.8 \mathrm{~cm}$ ), peroné (masculino patológico de $30.3 \mathrm{~cm}$, posee peroné en sable), 2 calcáneos, 2 astrágalos, 18 falanges y metapodios, 1 atlas fragmentado y 2 fragmentos del cráneo.
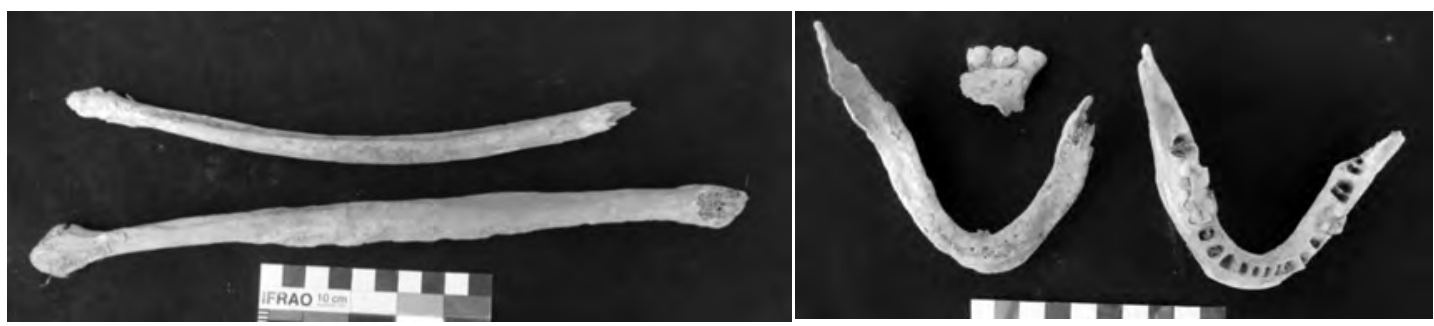

Figura 54 (izquierda): Peroné izquierdo humano con trauma curado que afectó la diáfisis con intensa rugosidad, individuo masculino, Contexto Funerario 1, unidad 14. Figura 55 (derecha): Mandibulas humanas de masculinos adultos fragmentados, contexto funerario 1 de la unidad 15.

\section{5.- Restos humanos de la Unidad 15}

En la capa D se identificó el Contexto Funerario 1, descrito líneas arriba. Las características de los dos individuos son: 2 mandíbulas adultas fragmentadas (masculinos), con evidencia de chacchado de coca y otro edentado, alveolos totalmente obliterados; 2 húmeros, 2 radios, 2 cúbitos, 4 fémures adultos (muy erosionados), 4 tibias muy desgastadas, 2 peronés fragmentados, 1 tibia izquierda (masculino mide $32.5 \mathrm{~cm}$ ), 1 rótula completa derecha de adulto. HV en las rodillas y tobillos. En asociación a estos óseos humanos se recuperó el hueso tarsiano derecho adulto de un puma (Felis concolor).

\section{VIII.- ANÁLISIS DEL MATERIAL OSEO ANIMAL}

Las excavaciones arqueológicas desarrolladas han permitido recuperar abundantes restos óseos de animales. La mayoría de estos restos animales han sido utilizados con fines alimenticios. Se ha recuperado una gran cantidad de restos de camélidos (alpacas, vicuñas y llamas), la mayoría con evidencias de haber sido sometidos al fuego, al parecer preparados como pachamanca o preparados con huatia. Además de los camélidos se han recuperado: restos de taruca (Hippocamelus antisensis) quemados, entre astas y huesos; restos de vizcacha (Lagidium peruanum); restos de cérvidos (Hippocamelus antisensis), cuy (Cavia porcellus), aves altoandinas, venado de cola blanca (Odocoileus virginianus), entre otros. Además se han recuperado restos óseos de animales utilizados como ofrendas funerarias o ceremoniales, como restos de camélidos, de zorro o Atoj (Pseudolopex culpaeus), zorrino o añas (Conepatus rex), aves altoandinas como el yanavico (Plegadis ridgwayi), el ayno o gallareta andina (Fulica ardesiaca), roedor pequeño o Ukush (Phyllotis pictus), cánidos (Canis familiaris), pumas (Felis concolor) y ranas procedentes de las lagunas cercanas (Batrachophrynus macrostomus).

Además se han recuperado huesos de animales trabajados, principalmente de camélidos, con el objetivo de elaborar artefactos como espátulas, cucharas, choqche o ruqui (instrumento textil) y flautas musicales; así como instrumentos ceremoniales como las illas, algunas de ellas encontradas con restos de cal que eran para ofrendar con coca. Se ha recuperado restos de charqui de camélido (alpaca). Además se recuperó una piedra pómez de procedencia marina, desgastada en sus bordes, asociada a restos óseos de camélidos, cérvidos y hojas de coca. 

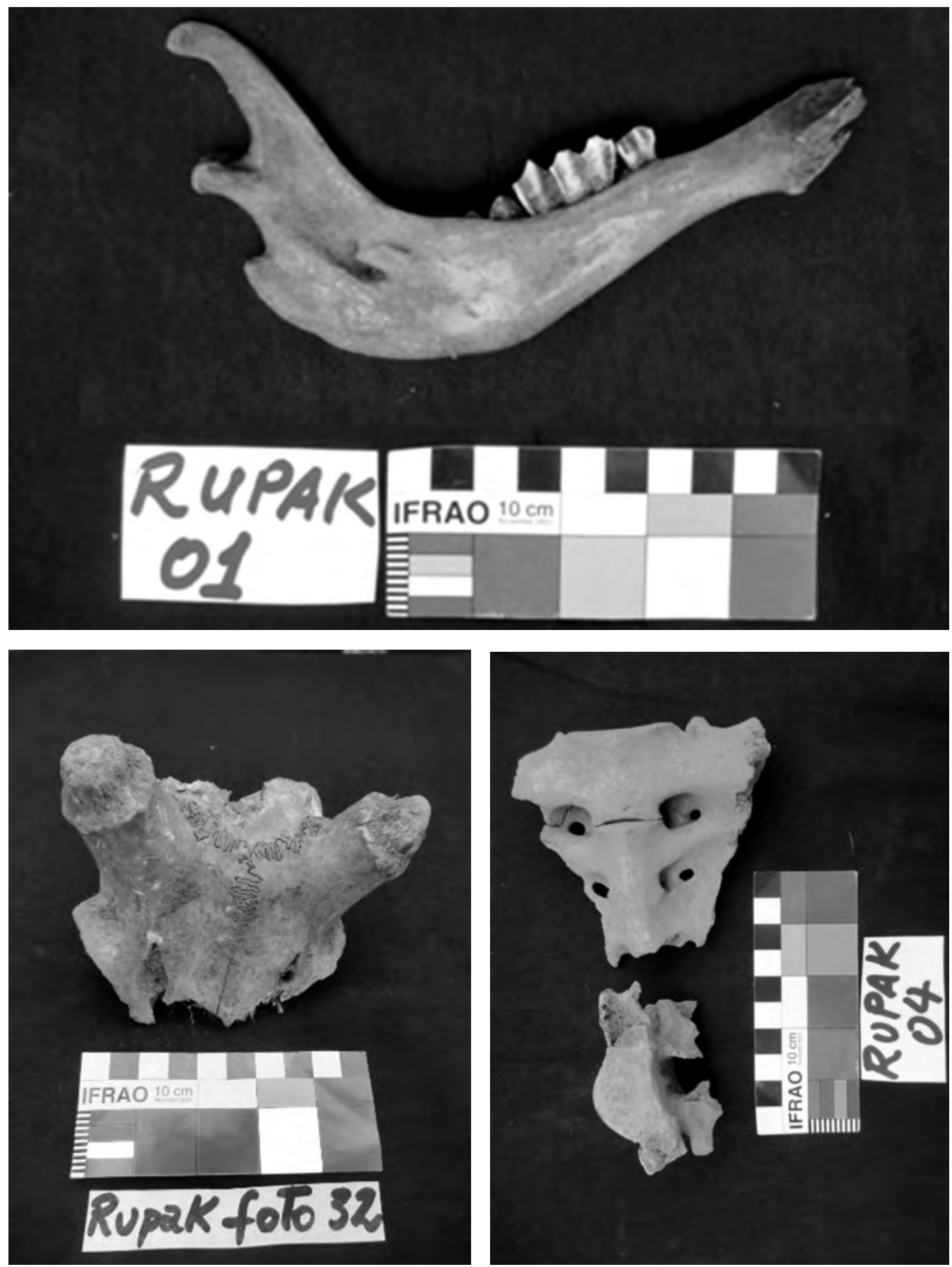

Figura 56 (izquierda): Mandíbula de camélido joven, probablemente alpaca (Vicugna pacos). Figura 57 (derecha): Una vértebra torácica patológica de camélido con crecimiento óseo lateral tipo espondilólisis y pérdida de la apófisis espinosa y un sacro con pérdida de la cresta sacral total. Figura 58 (derecha): Frontal de venado trabajado en la base de sus astas. 

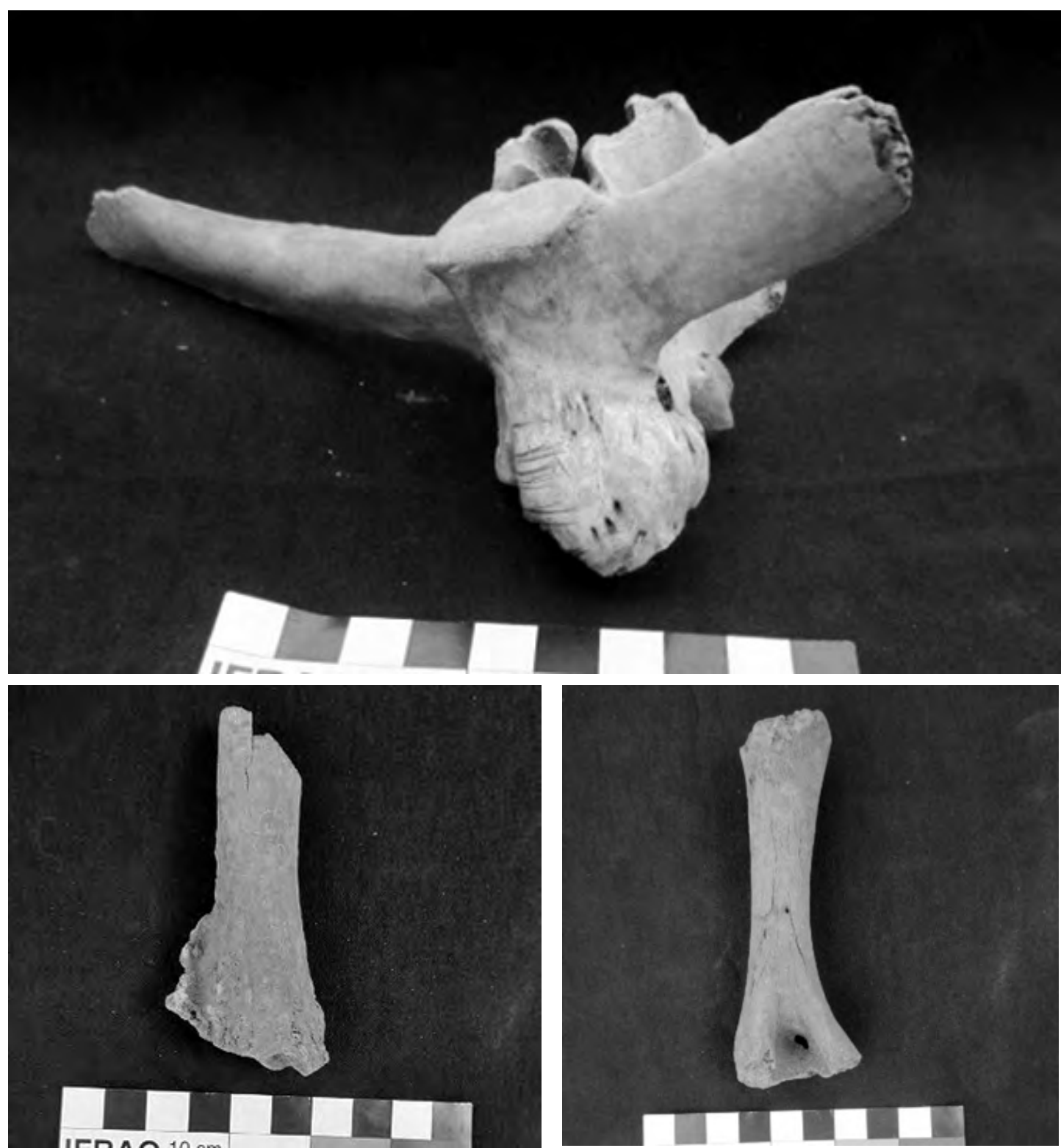

Figura 59 (izquierda): Vértebra lumbar de alpaca robusta con espondilólisis pronunciada o "pico de loro". Nótese las marcas de corte en el cuerpo vertebral. Figura 60 (centro): Epifisis distal de radio de cérvido con patología, crecimiento óseo lateral. Figura 61 (derecha): Húmero izquierdo de alpaca joven acondroplásico. 

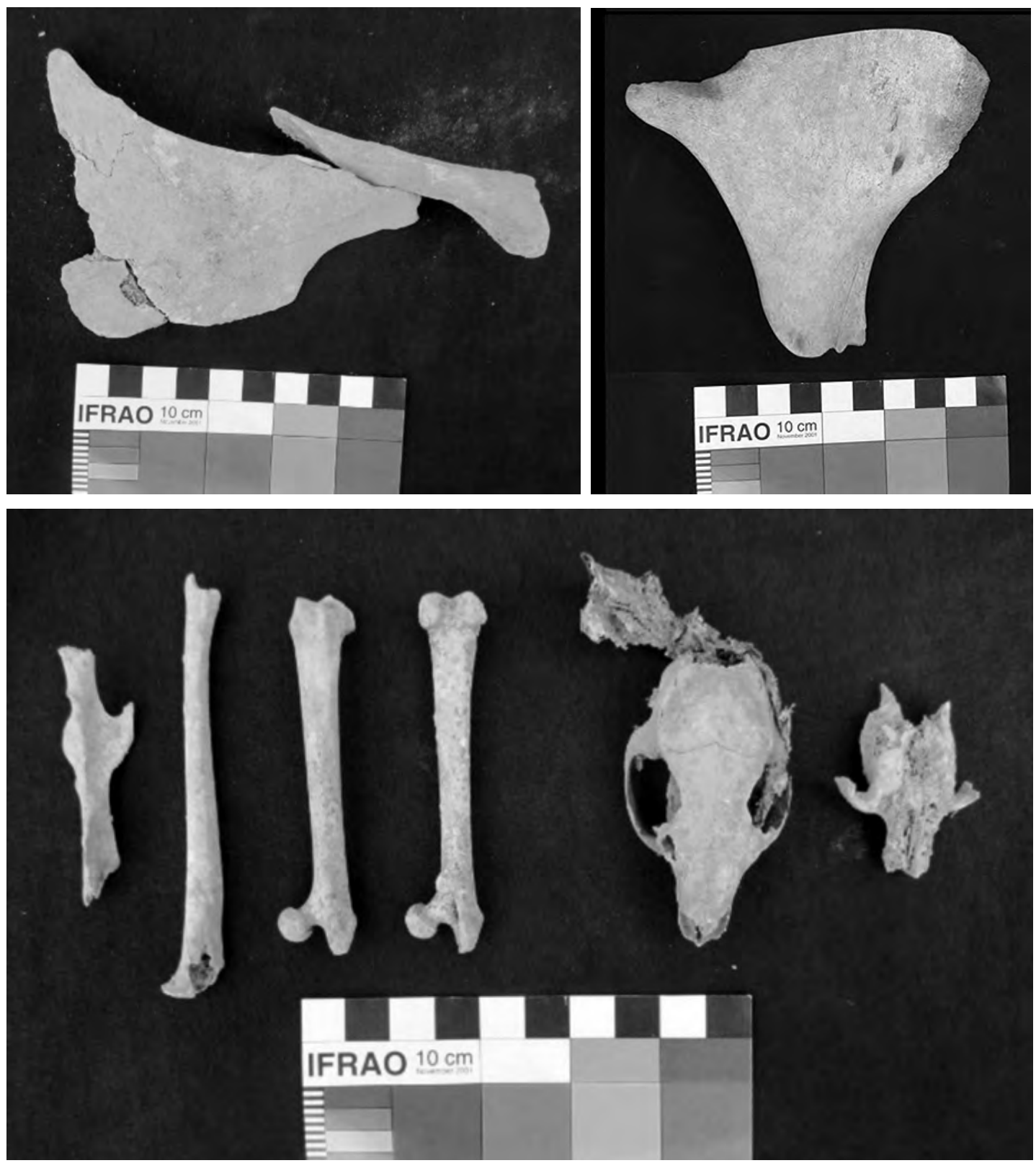

Figura 62 (izquierda): fragmentos de Illa de pelvis de camélido. Figura 63 (centro): Illa de pelvis de camélido. Figura 64 (derecha): Cráneos de vizcachas adultos, pelvis, fémures y tibia de ofrenda. 

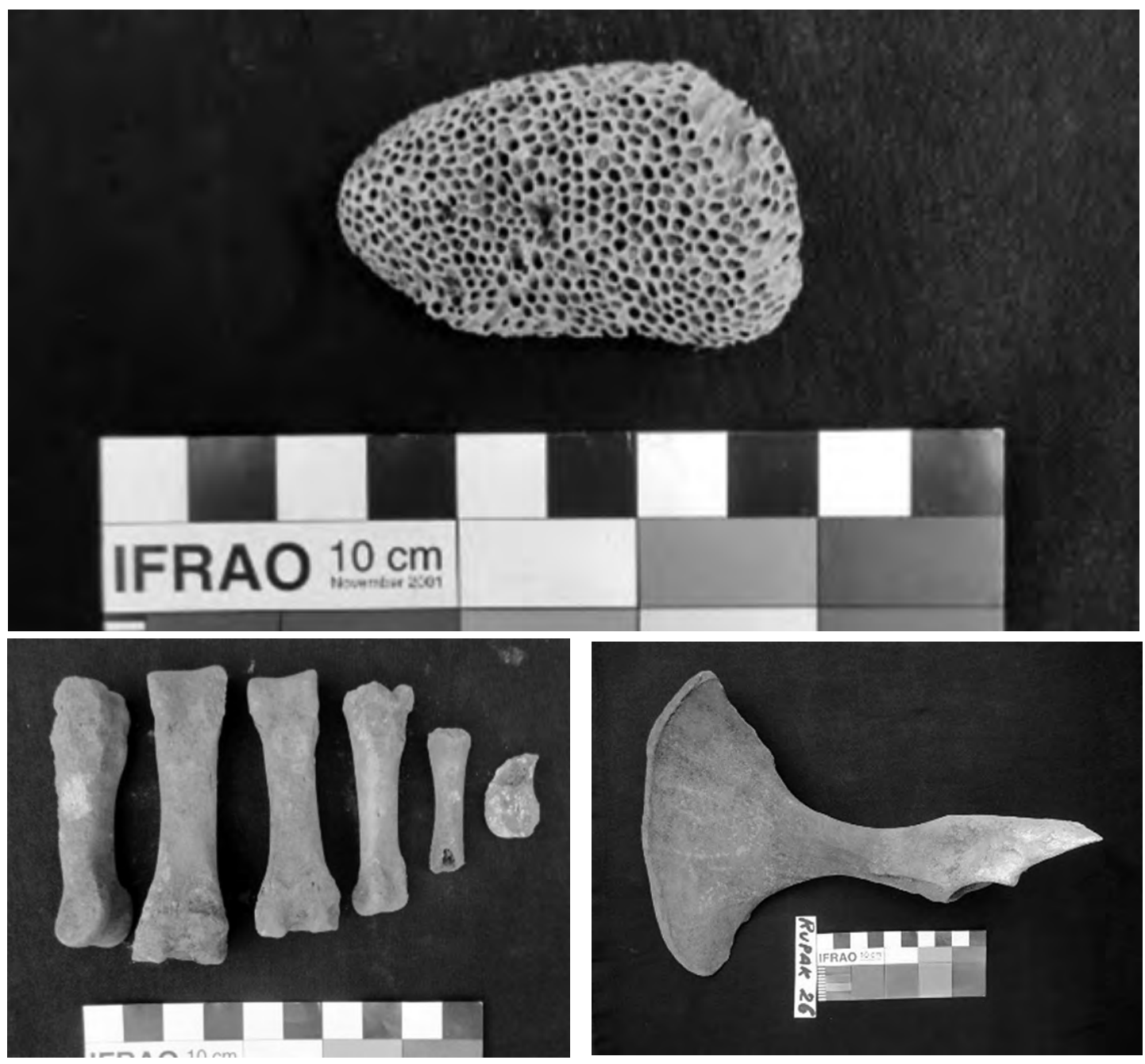

Figura 65 (izquierda): Piedra pómez desgastada de procedencia marina. Figura 66 (centro): Falanges de alpacas relacionadas a ritos funerarios en Rupak. Figura 67 (derecha): Illa de pelvis de camélidos adulto. 

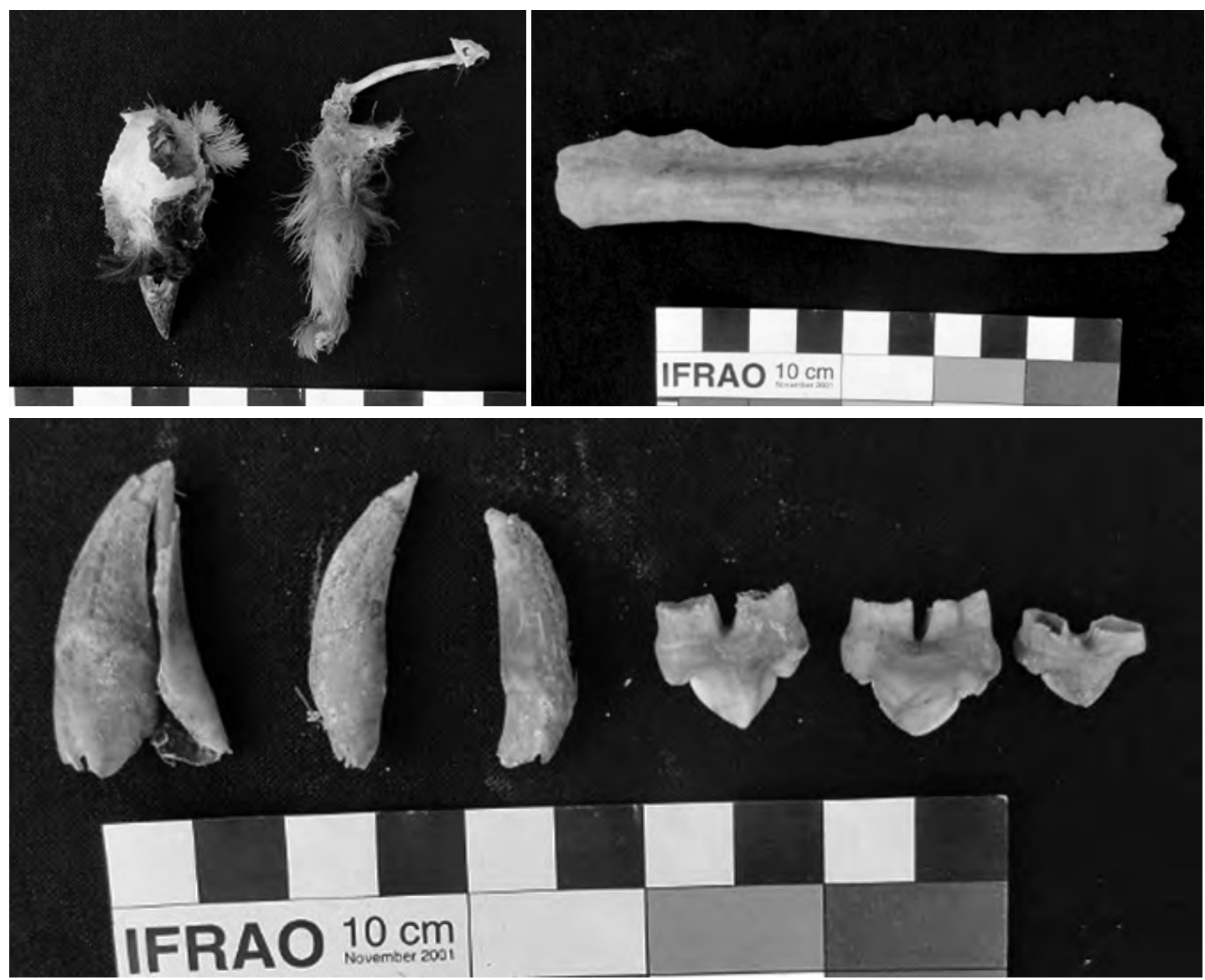

Figura 68 (izquierda): Yanawico: 1 cráneo completo y un ala derecha con plumas blancas y negras adulto. Figura 69 (centro): Dientes de puma joven. Figura 70 (derecha): Chocche o ruqui de llama adulta. 


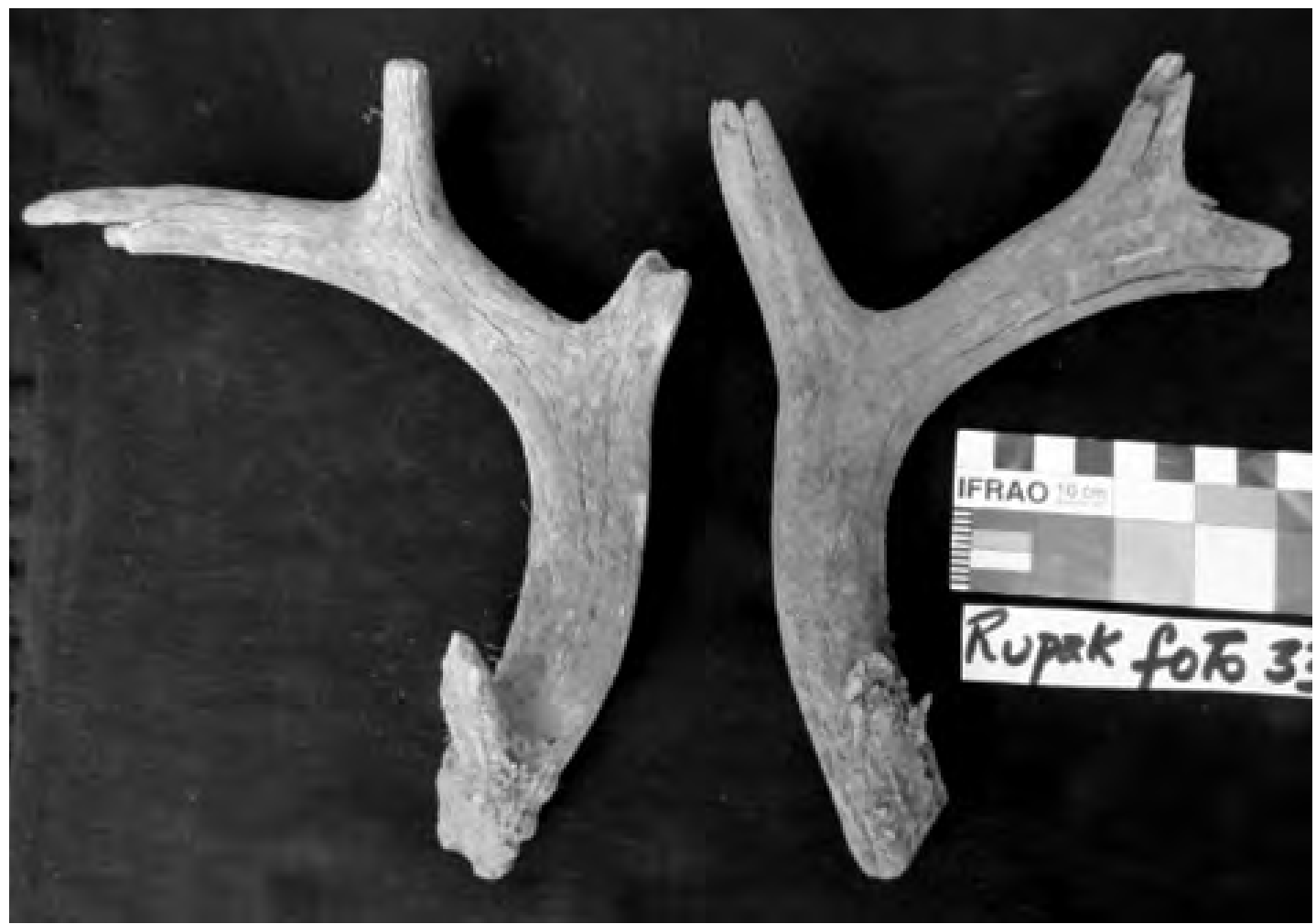

Figura 71: Astas de venado de cola blanca con fracturas en los ápices.

De las especies identificadas en las excavaciones las que tienen mayor densidad son los camélidos. En un anterior trabajo (van Dalen, Altamirano, Grados y Castillo; 2014), se presentó las características y gran presencia de estos animales domésticos en periodos tardíos en el valle medio del río Chancay a partir de los materiales recuperados en el sitio de Lumbra. El uso de camélidos tuvo múltiples funciones: como medios de transporte y de carga, con fines alimenticios, con fines ceremoniales, para la obtención de su fibra y fabricación de tejidos, entre otros.

\section{IX.- El MATERIAL CERÁMICO}

Se ha identificado una cerámica local que hemos definido como estilo Atavillos, dentro del cual hemos identificado el tipo doméstico sin decoración, el tipo engobe rojo pulido y el tipo engobe negro pulido. Este estilo se encuentra en los estratos del Intermedio Tardío y del Horizonte Tardío (en estos últimos asociados al estilo Inca Local). Para los estratos del Horizonte Tardío se ha recuperado en regular densidad fragmentos del estilo Inca Local, así como escasos fragmentos del estilo Inca Provincial. Solo se ha recuperado pocas vasijas completas, asociadas a los contextos funerarios.

\section{X.- LAS CÚPUlas}

Otro aspecto que resulta importante en la arqueología del sitio de Rupac, es la presencia de cúpulas, tanto en el sector C como en el D (Marca Kullpi). Las cúpulas son grandes bloques de piedra en cuyas caras casi planas se han elaborado hoyos con fines astronómicos. Querejazu Lewis (2011) divide las cúpulas prehispánicas en tres grandes categorías: por su funcionalidad ritual, utilitaria y las que 

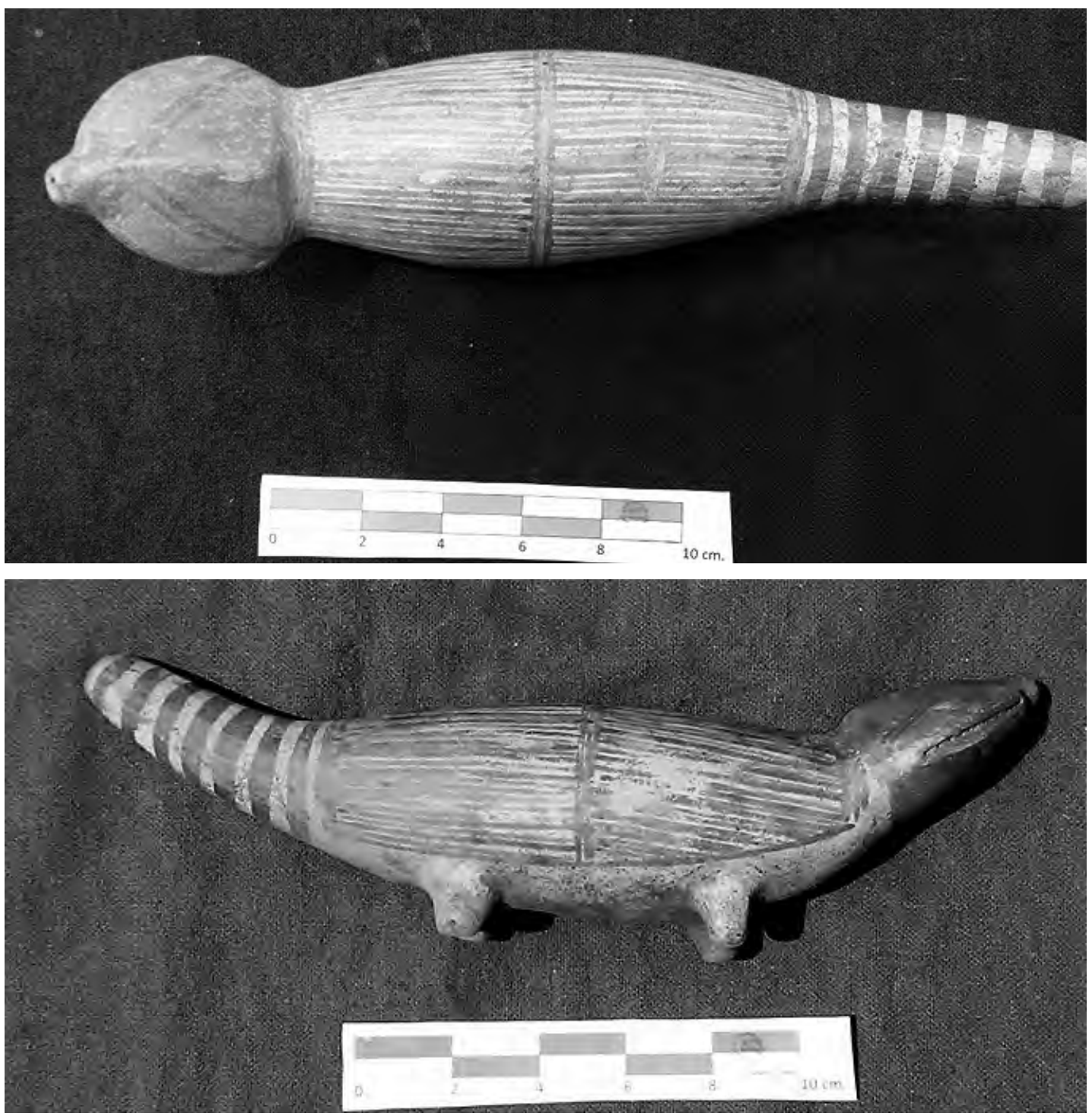

Figuras 72 y 73 (superior e inferior): Dos vistas de la vasija modelada zoomorfa de estilo Tawantinsuyu provincial.

tenían un importante simbolismo; sin embargo, agrega una cuarta: cúpulas sometidas a un re-uso en la actualidad. Jean Guffroy (2011), las clasifica en tres tipos de acuerdo a sus diámetros y profundidades: 1.- Las copas, "de mayor circunferencia pero con reducida profundidad", asociadas a arquitectura del fin del Formativo o junto a otras manifestaciones rupestres. Señala que representan una fase temprana. 2.- Los pocitos, "con una profundidad superior a su diámetro", aparecen asociadas o junto a otros petroglifos. Son comunes en Loja (Ecuador), Piura y en Jaén; difícilmente podrá ubicárseles en la costa central y sur. 3.- Finalmente las cúpulas, cuyo diámetro es inferior a $5 \mathrm{~cm}$, han sido reportadas en sitios de la costa norte y central. Como hemos señalado las cúpulas de Rupac han sido identificadas en dos sectores: 
A.- Cúpulas del sector C.- El soporte es una roca diorita aflorante, de $0.80 \mathrm{~m}$ (en eje W - E) y 0.74 $\mathrm{m}$ (en eje $\mathrm{S}-\mathrm{N}$ ). El método empleado en los diseños es la percusión y el frotado o pulido con artefactos líticos, los cuales se centraron en crear hoyos circulares y ovalados de distintos diámetros y profundidades. El soporte fue dividido en dos partes mediante desgaste ovalado en forma de canaleta que circunda en los extremos al soporte, creando en total dos espacios. En la parte interna se contabilizaron en total 92 cúpulas, las cuales se dividen en dos categorías: una cúpula principal y 91 cúpulas secundarias.

B.- Cúpulas del sector D (Marca Kullpi).- En este sector se registró dos grupos de cúpulas, asociadas a espacios abiertos o patios formados por los Kullpis y Chullpas. Esta cúpula se ubica al extremo sur del sector, ubicado en un espacio abierto y rodeado por edificios, área que interrelaciona distintas unidades habitacionales. El soporte (piedra) se encuentra orientado al este, ya que la parte más aguda de la roca se encuentra hacia este lado. La cara del soporte se encuentra ya en proceso de deterioro, presenta una superficie semiplana y rugosa. Presenta una leve inclinación al norte. La piedra es de granodiorita. El método usado para la elaboración de la cúpula es la percusión y la presión, con lo cual se logró crear los hoyos o pocitos. Los elementos de diseño están conformado por cúpulas de diversos tamaños, los cuales varían de $2.2 \mathrm{~cm}$ a $6 \mathrm{~cm}$ de diámetro y de $0.2 \mathrm{~cm}$ a $1.6 \mathrm{~cm}$ de profundidad. Estos hoyos se dividen en 6 grupos, delimitados por las áreas rayadas que encierran un cierto número de ellos. Entre todas estas resalta una cúpula de mayor dimensión a todas, la cual se trataría de la representación central ya que las demás se dispersan alrededor de ella, en algunos casos formando líneas orientadas al noroeste. En total se contabilizan 63 cúpulas. La superposición de los elementos está dado por la canaleta que une dos cúpulas, realizada luego de estas, se notan 4 de ellas, ubicadas en distintos grupos. Otra superposición está dada por los rayados, donde se notan tres líneas formado un triángulo, estos rayados pasan sobre algunas cúpulas, pudiendo ser posiblemente tardías. Naturalmente se encuentra afectado por los líquenes y hongos, los cuales junto a la humedad exfolian progresivamente a la pared rocosa.

\section{XI.- OTROS MATERIALES CULTURALES}

Se ha recuperado de las excavaciones escasos restos botánicos (debido a las condiciones climáticas del medio) compuestos por: tusas de maíz (Zea mays), restos de mates (Lagenaria siceraria), pepas de lúcuma (Pouteria lucuma), entre otros. De igual manera se recuperó pequeños retazos textiles llanos de 1x1. Además existen instrumentos musicales, conformados por flautas hechas en huesos de camélidos. Entre el material lítico recuperado figuran: batanes y manos de moler, porras, puntas de proyectil, piedras de huaraca, entre otros. Se recuperó también instrumentos suntuosos de metales, conformados por: tupus, prendedores, láminas circulares de pectorales, pinzas, entre otros; elaborados de cobre, oro, plata y tumbaga.

\section{XII.- INTERPRETACIONES SOCIALES}

\section{1.- PERIODOS DE OCUPACIÓN DEL SITIO}

El sitio arqueológico de Rupac, presenta dos periodos de ocupación bien marcados, los cuales se pueden apreciar tanto en la arquitectura, como en los materiales recuperados de las excavaciones:

Intermedio Tardío (Atavillos): comprendida entre los 800 a 1470 d. C. En este periodo se asientan poblaciones locales, agrupadas en marcas o ayllus, pertenecientes a la cultura Atavillos. Se caracteri- 


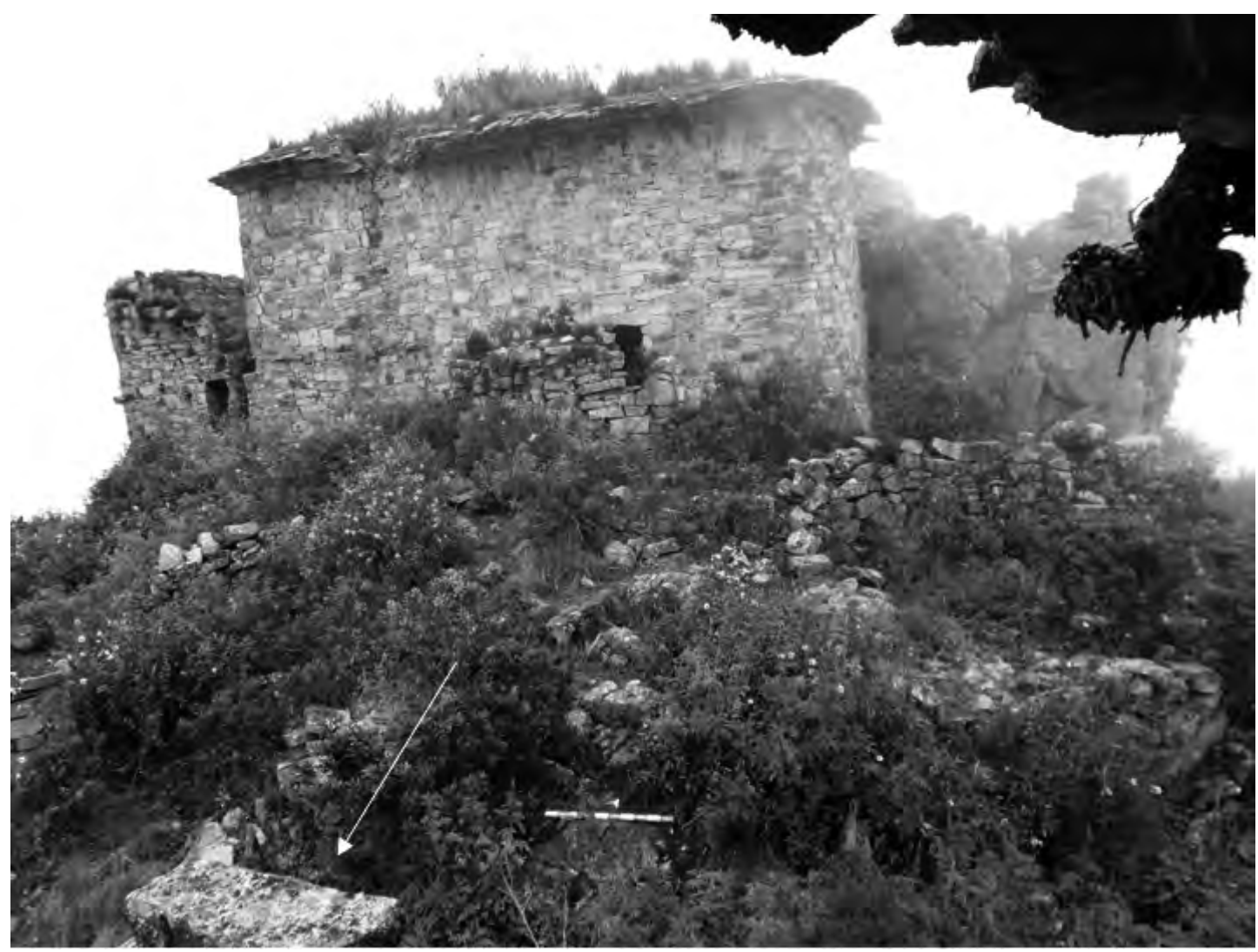

Figura 74: Vista de la cúpula de Marca Kullpi en el espacio abierto.

zan por la construcción de edificaciones de tipo Kullpi (funerario- doméstico) y chullpa (netamente funerario, de carácter secundario y de entierros múltiples), principalmente. Estas edificaciones se encuentran emplazadas sobre la cima de los cerros, con un amplio dominio de la cuenca alta y los valles aledaños. En cuanto al material recuperado de las excavaciones en Rupac para este periodo se puede mencionar: la cerámica, los implementos de uso doméstico, instrumentos textiles, artefactos de caza, armas bélicas, instrumentos musicales, objetos suntuarios de metal y por último los entierros en cámaras subterráneas y cámaras secundarias en niveles superiores del Kullpi. En cuanto a la cerámica se ha podido identificar dos estilos del mismo periodo. Un estilo foráneo denominado Cayash del tipo Quillahuaca (Krzanowski 1991), que suele aparecer esporádicamente en contextos domésticos y en cantidades mínimas. El segundo estilo propio de la zona, denominado como estilo Atavillos, con dos tipos: el primer tipo doméstico, de pasta llana de color marrón-rojizo, de acabado alisado, sin decoración, representado por platos, ollas, cuencos y vasos; se los identificó asociados a los contextos domésticos, basura arqueológica, quemas y fogones, casi siempre con hollín impregnado en las paredes de las vasijas. El segundo tipo de engobe y pulido fino, asociado a los contextos funerarios, se trata de fragmentos de cerámica fina de pasta marrón-rojiza, con engobe negro y/o rojo y de acabado pulido. Los objetos de uso doméstico están representados por las vasijas (ollas, cuencos, platos), batanes, manos de moler, raspadores, cortadores y cuchillos. Asociado con la textilería se identificó piruros de cerámica (se reutiliza los fragmentos domésticos o finos, osamentas de animales y líticos). Los instrumentos de caza son las puntas líticas y proyectiles. Se han identificado armas como las preformas 


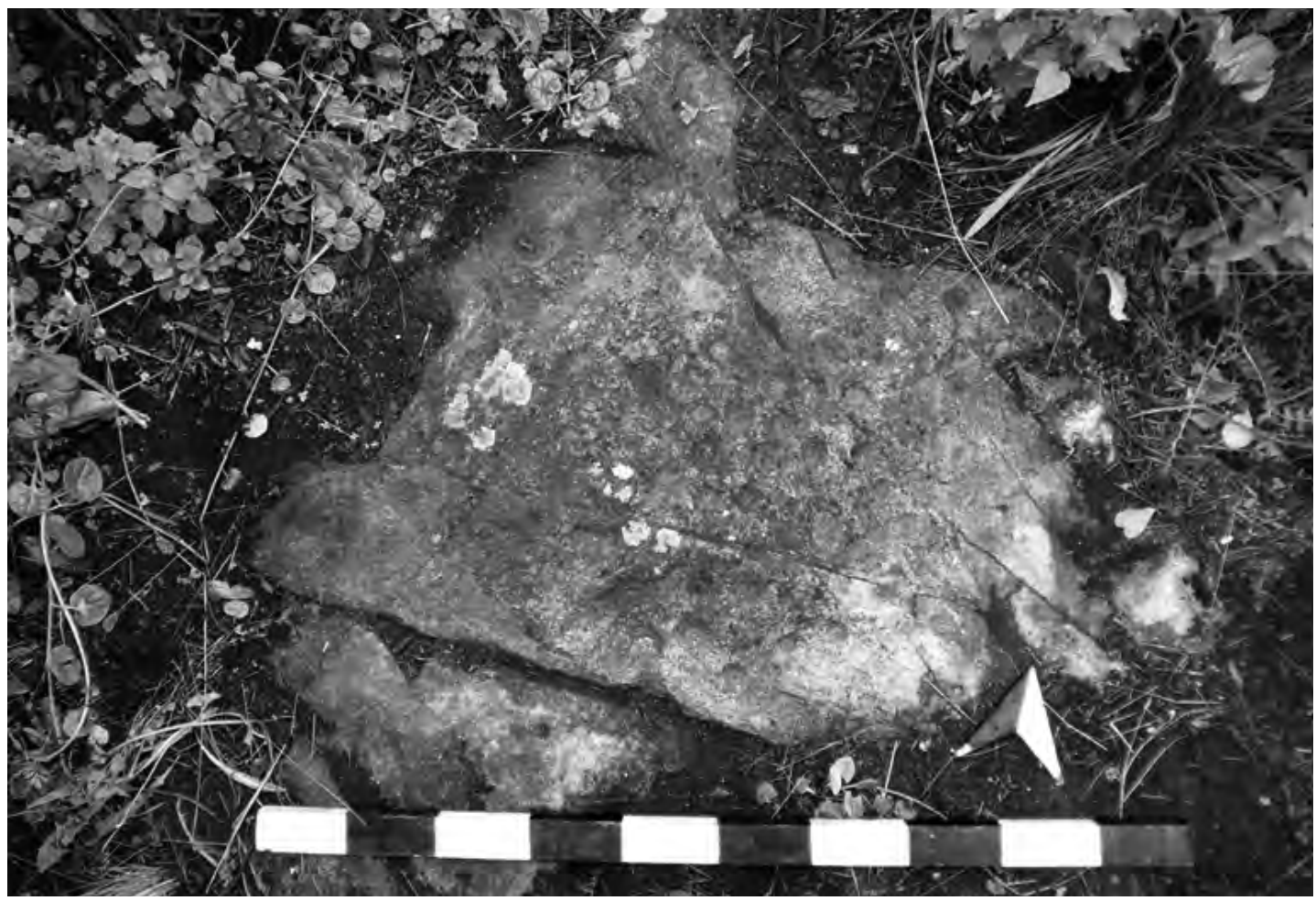

Figura 75: Vista general de la cúpula de Marca Kullpi.
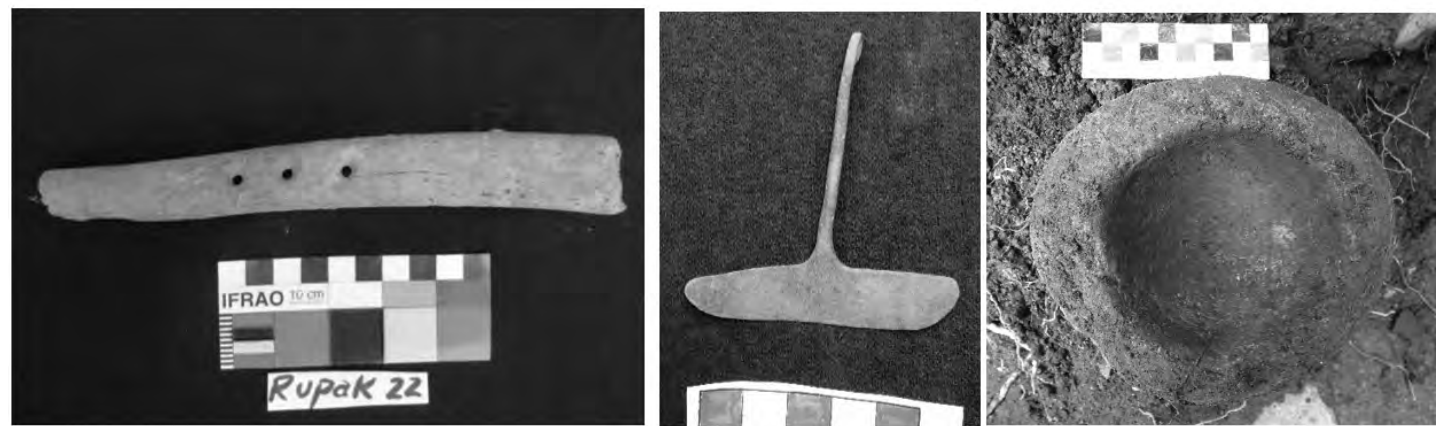

Figura 76 (izquierda): Flauta de hueso de camélido. Figura 77 (centro): tupu de oro. Figura 78 (derecha): batán de piedra.
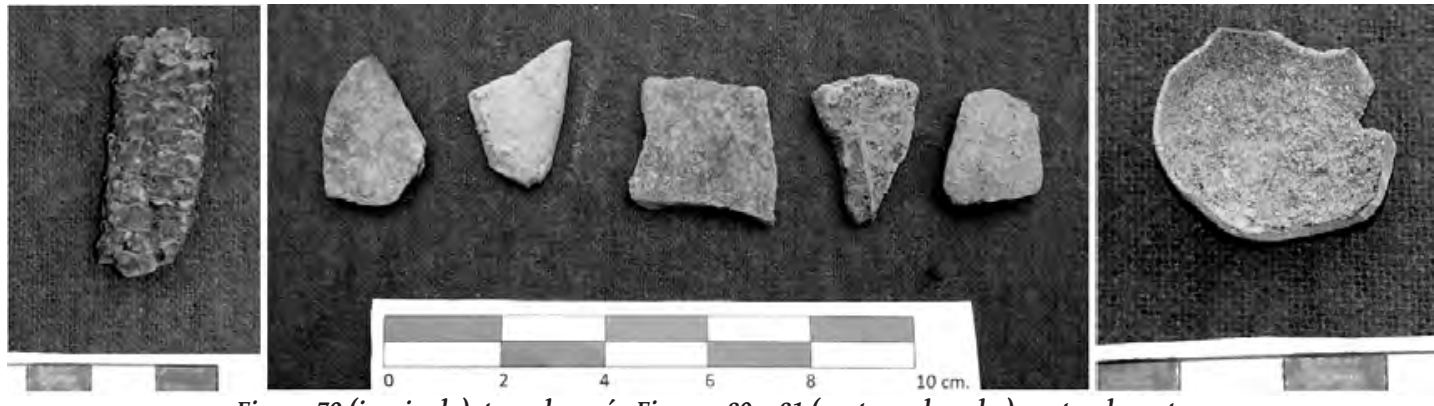

Figura 79 (izquierda): tusa de maíz. Figuras 80 y 81 (centro y derecha): restos de mates. 

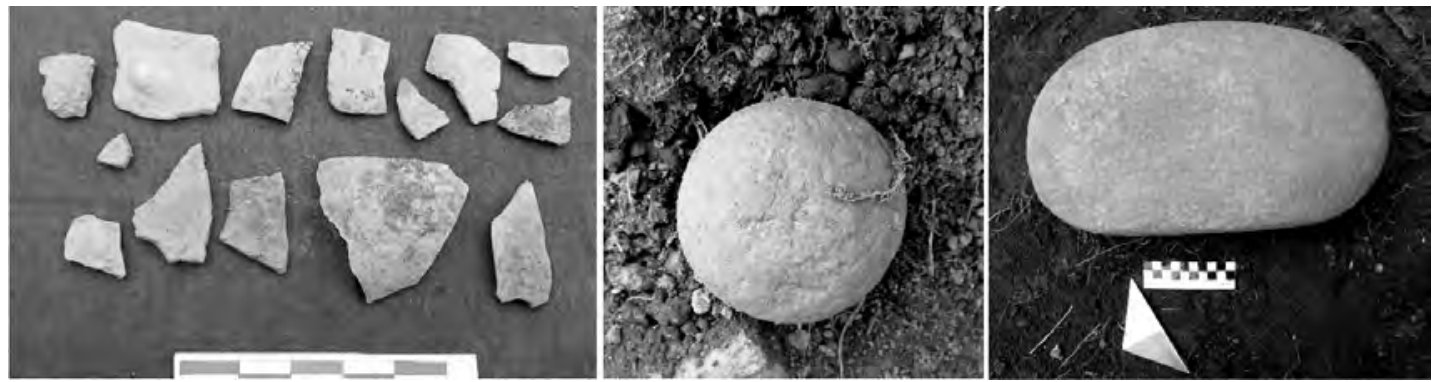

Figura 82 (izquierda): restos de mates. Figura 83 (centro): proyectil de huaraca. Figura 84 (derecha): moledor lítico.
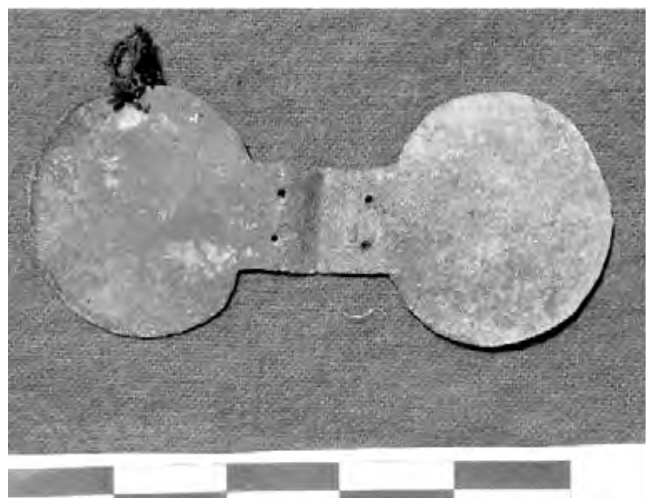
(20)

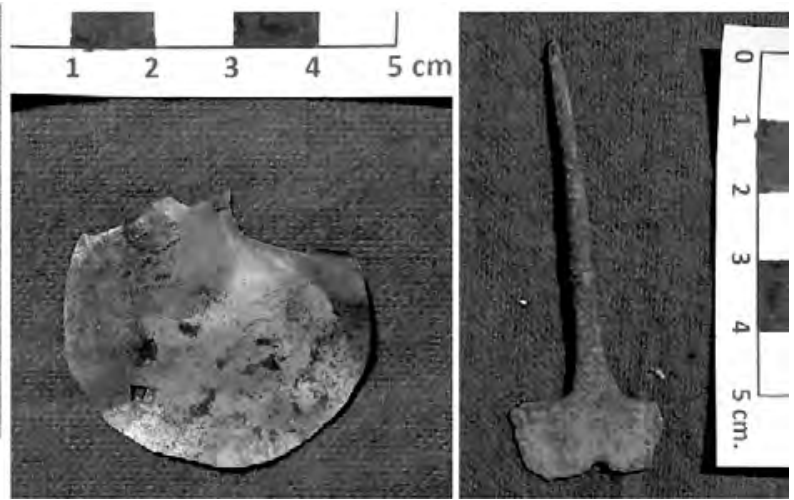

Figuras 85, 86 y 87 (izquierda, centro y derecha): objetos suntuarios de metal.

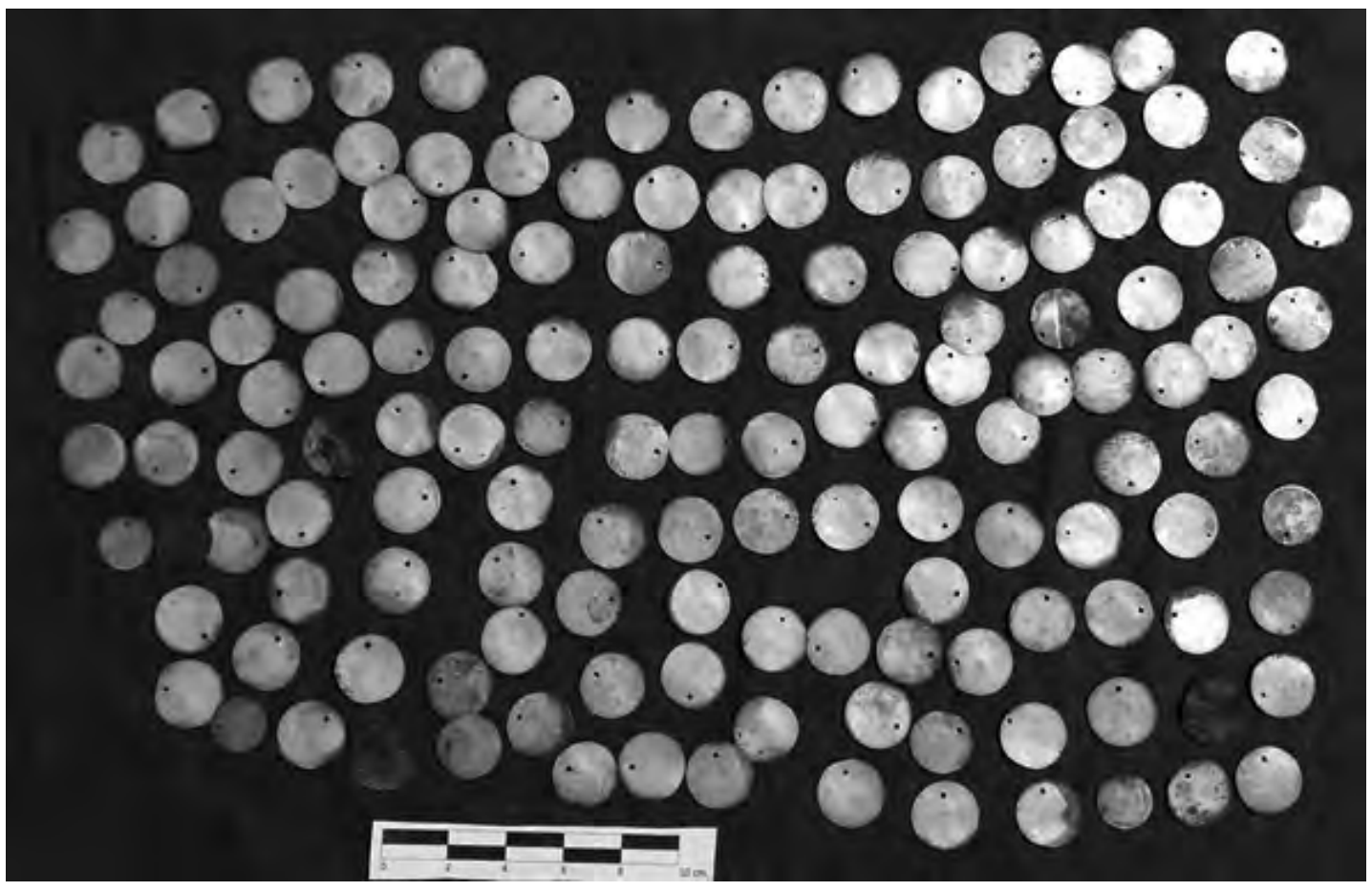

Figura 88: láminas circulares de plata que formaban parte de un pectoral. 
de porras y porras circulares, así como proyectiles para ser usados con las huaracas. Se han podido identificar instrumentos musicales de viento (flautas) hechos de osamenta animal. Los entierros se caracterizan por hallarse en cámaras subterráneas o cámaras secundarias y en los niveles superiores de los kullpis; asociados a estos entierros se identificó vasijas del tipo engobe fino así como objetos suntuarios de metal (cobre, plata y oro): laminas circulares, pinzas, tupus, orejeras, etc.

Horizonte Tardío (Atavillos-Inca): comprendida entre los años 1470 a 1533 d. C. Este periodo está caracterizado por la incursión Inca en la zona, su conquista y la anexión de estos territorios al Tawantinsuyu. Sin embargo por las características identificadas a nivel arquitectónico y en las excavaciones, se puede apreciar una coexistencia de la población local con los representantes del Estado cuzqueño, relacionado con el desarrollo y control del culto a los mallquis, hasta la llegada de los españoles y la reducción de pueblos. Las edificaciones locales siguen funcionando simultáneamente a los edificios ocupados por los incas, los cuales presentan modificaciones, remodelaciones e inclusiones de elementos arquitectónicos incas sobre los kullpis, estos últimos modificados para crear edificios administrativos estatales, con construcciones en técnica y material local. Se ha podido identificar tres kallancas y un "cabildo", edificios que sirvieron simbólicamente para controlar o imponerse ante la población local. En las excavaciones se ha podido corroborar estos datos, ya que tres de estos edificios fueron excavados, recuperándose material arqueológico Inca; principalmente fragmentos de cerámica del tipo Inca local e Inca provincial, porras, proyectiles y contextos funerarios cuyas vasijas asociadas tienen formas aribaloides. Esta cerámica del tipo Atavillos-Inca o Inca local, se caracteriza por presentar pasta local, acabado alisado, es decir presenta las características locales, lo único que cambia son las formas de las vasijas (al estilo inca) y los labios evertidos. La cerámica del tipo inca provincial está representada por fragmentos con decoración propia del estado cuzqueño, al parecer elaborados por grupos mitqmas, de pasta no local, que habría sido traídas de centros administrativos cercanos como Pumpu o Huánucopampa.

\section{2.- Funcionalidad del Sitio}

Para determinar la funcionalidad del sitio arqueológico de Rupac, se propuso la excavación en el interior de los Kullpis y en los espacios abiertos, no se excavó en las chullpas ya que por estudios anteriores y por lo observado en las prospecciones se pudo determinar su funcionalidad, ciertamente funeraria. De los edificios tipo Kullpi que se excavaron, un $90 \%$ de ellos presenta tres niveles funcionales identificados. El primer nivel o cámara subterránea, fue destinada exclusivamente para el depósito de muertos, es decir entierros primarios, los cuales registran ofrendas (vasijas con alimentos). En el segundo nivel o cámara principal, se desarrollaban actividades domésticas, se identificó un área de cocina (quemas, fragmentos de cerámica con presencia de hollín, restos de osamenta quemada, etc.) y área de desecho de los alimentos consumidos (semillas, tusas de maíz, etc.); lo peculiar es que el grosor de estos estratos no pasan de los 3 a $5 \mathrm{~cm}$, en intervalos, donde se aprecia desocupación por un tiempo determinado (cubierto con tierra limpia) y luego vuelven a verse ocupaciones en estratos pequeños de desperdicio de consumo, y así sucesivamente. El tercer nivel o cámaras secundarias, eran utilizados multifuncionalmente, es decir, algunas veces para almacenar alimentos, otras para depositar osamenta humana desarticulada (cráneos y huesos largos) y en algunos casos para ofrendar alimentos o animales (cuyes y aves de la zona). Por lo tanto los kullpis de Rupac, fueron utilizados esporádicamente para albergar personas en determinadas épocas del año, ello se puede deducir por los estratos de ocupación muy breve, pero periódicos, en intervalos; sin embargo se puede ver que esta estadía se daba por pocos días. Si recurrimos a la comparación etnográfica con tradiciones o rituales actuales de las comunidades de la cuenca alta del río Chancay-Huaral y las comunidades del cercano 
mantienen este ritual o culto a sus muertos o ancestros, con muchas semejanzas a lo observado en Rupac, en las formas de sus rituales asociados a la muerte, donde esporádicamente los cementerios o espacios funerarios son concurridos por los familiares o descendientes, quienes realizan actividades rituales (los muertos son consultados y se les hace pedidos entre ofrendas de coca, licores y cigarros), domésticas (preparación de alimentos y bebidas para los muertos), sociales (se genera un vínculo de cercanía y parentesco con los ancestros y sus descendientes) y religiosas; finalmente al culminar la conmemoración se retiran hasta el siguiente año. También se puede inferir el culto a los ancestros, mediante la ofrenda de alimentos en los entierros, así como animales asociados a estos. Gran parte del primer y tercer nivel del Kullpi fueron construidos con el propósito de albergar a los muertos, con fines rituales y de conmemoración. En este sentido, se nota en los Kullpis una organización tripartita, donde el nivel inferior y superior se encuentran los ancestros, en clara relación con el Hurin pacha y Hanan pacha, respectivamente; mientras que el nivel intermedio que representa el Kay pacha está relacionado con los vivos y descendientes de los ancestros, quienes periódicamente los visitan para los rituales funerarios, a fin de lograr la interacción social entre muertos y vivos, es decir entre ancestros y descendientes.

En el caso de los espacios abiertos como patios o plazas, fueron destinadas a áreas públicas de reunión, congregación y lazo familiar; de acuerdo a las excavaciones se puede decir que fueron utilizados para la interacción social a través de actividades conjuntas; en los patios se dieron actividades domésticas, donde se puede apreciar la producción de artefactos de textilería y en algunos casos estos patios eran utilizados como botadero de desperdicios de consumo. En el caso de la plaza, habría servido como lugar de congregación de toda la población para los actos rituales, asociados a las cúpulas que se hallaron en el centro de dicha plaza, quizá como ritos mágico-religiosos antes de la conmemoración a los muertos o ancestros que se tenía que hacer en los kullpis.

Por último la función de las edificaciones tipo Inca, que fueron remodeladas al diseño y trazo de la arquitectura inca, exclusivamente sirvieron (los niveles dos y tres) para albergar a los representantes estatales con el objeto de lograr un control de las áreas rituales locales, almacenar sus alimentos y armas; además se halló contextos funerarios con objetos incas. El "cabildo" por su parte sirvió como centro administrativo y de control para poder tener control sobre la población local, a través de alianzas directas o quizá por medio del control directo por imposición del ejército imperial.

\section{3.- El culto a los ancestros en Rupac}

A partir de las investigaciones desarrolladas podemos afirmar que Rupac se constituyó en un complejo arqueológico donde la actividad principal se relacionaba con el culto a los ancestros, es decir en un lugar donde el pasado y el presente interactuaban a partir del culto a los muertos, a fin de lograr consolidar la unidad social en el presente por los vivos.

\section{X.- Conclusiones}

Entre las conclusiones a las que se ha llegado con la presente investigación figuran:

Rupac es un extenso asentamiento conformado por cuatro amplios sectores y con ocupación durante los periodos Intermedio Tardío (Atavillos) y Horizonte Tardío (Atavillos-Tawantinsuyu).

Predomina en Rupac la arquitectura tipo kullpi: de grandes dimensiones, complejidad espacial y hasta $7 \mathrm{~m}$ de altura. Además predomina también las estructuras funerarias tipo chullpa.

Las excavaciones en el interior de los kullpis, permitieron conocer la funcionalidad y los periodos de ocupación. Los kullpis fueron utilizados como edificaciones funerarias a modo de mausoleos con 
una organización tripartita: se enterraba a los muertos o ancestros en las cámaras subterráneas; en la cámara principal o nivel dos se daban actividades domésticas y rituales relacionadas al culto y conmemoración de los mallquis; mientras que en las cámaras secundarias o niveles superiores se ofrendaban comida, se depositaban contextos funerarios secundarios (cráneos y huesos largos) y animales (cuyes, aves o cérvidos) relacionados con los individuos del primer nivel, siempre relacionados al culto a los muertos. Estas costumbres del culto a los muertos aún se dan en gran parte de los Andes Centrales (la cuenca alta del río Chancay-Huaral y gran parte de Pasco).

Se identificó edificaciones administrativas de tipo Kallanca, las cuales fueron instauradas a la llegada de los Incas, como imposición y símbolo de dominio. Se estableció un "cabildo" que servía como edificio de control y símbolo de poder. En esta edificación se hallaron entierros y ofrendas como parte de su construcción, símbolo de su importancia y jerarquía.

También se identificó edificaciones de ocupación y función netamente doméstica, los cuales fueron ocupados en el Horizonte Tardío.

Los espacios abiertos como patios y plazas fueron utilizados para reunir y congregar población. En los patios se desarrolló actividades domésticas vinculadas a la textilería, el consumo y desecho de alimentos. Estos habrían estado relacionados con el proceso y ritual del culto a los ancestros, la preparación de comida y el hilado de textiles que sirvieron como ajuar funerario, lo cual serviría para renovar los objetos, alimentos y vestimentas del ancestro. La plaza habría cumplido una función de congregación de la población, como antesala de los ritos funerarios en los kullpis y chullpas.

En cuanto a la ocupación de Rupac, se puede mencionar dos periodos claros, contrastados mediante las excavaciones y apoyándonos en la diferenciación de la arquitectura. En el Intermedio Tardío, se dio una ocupación local, principalmente de los Atavillos, con construcciones de tipo Kullpi y Chullpa, cuya cerámica está representada por el estilo Atavillos, de dos tipos: el doméstico-llano (asociado a actividades domésticas) y el de acabado pulido-fino (vasijas que servían como ofrenda para los entierros). El Horizonte Tardío, se caracteriza por la llegada de los incas a la zona, sin embargo se da una coexistencia, aun se siguen utilizando las edificaciones, aunque la funcionalidad cambia, ya para este periodo se reocupan algunas edificaciones y son remodeladas con fines administrativos. Se construyen kallancas y un "cabildo" como áreas administrativas y símbolos de poder e imposición. Las edificaciones mantienen la técnica y manufactura local, solo cambia o se adiciona elementos arquitectónicos incas (los vanos se hacen trapezoidales, la cubierta cambia de lajas de piedra, a cubierta a dos aguas, los espacios internos son más amplios y las esquinas de los edificios son ortogonales). La cerámica de este periodo está representa por fragmentos de tipo Inca-local (la pasta de la cerámica es local, solo cambian las formas de vasijas) e Inca-provincial (vasijas foráneas, traídas de centros administrativos estatales cercanos).

La mayoría de individuos humanos identificados se caracterizan por presentar modelación cefálica del tipo semi horizontal, típico de la cuenca alta del río Chancay (Atavillos), lo cual servía como símbolo de identidad social.

\section{XI.- RECONOCIMIENTOS Y AGRADECIMIENTOS}

Un especial reconocimiento al Rectorado de la Universidad Nacional Mayor de San Marcos, dirigido por el Dr. Pedro Cotillo Zegarra por el financiamiento y auspicio de los trabajos de investigación. A la Comunidad Campesina San Salvador de Pampas por las facilidades y autorizaciones respectivas para el desarrollo del proyecto. A los estudiantes y profesionales que han participado en las investigaciones, además de los autores del presente artículo figuran: Bach. Rubén Cisneros Cárdenas, Bach. 
Rosa Carlos Izquierdo, Bach. Luis Reymundo Lume, Bach. Angélica López Carhuas; a los estudiantes: Nilver Serván Mendoza, Yerovi Marcelo Gonzáles, Yesenia Huashuayo, Juan Carlos Pérez Núñez, Carina Paullo Mendoza, Héctor Carhuas Tenorio, Kelly Ibarra, Alfredo Carbajal, Carlos Sairitupac, Elvis Casani, Elder Alcozer, el conservador Ángel Alfaro; todos trabajando bajo adversidades climáticas constantes con mucho ímpetu. Un reconocimiento al Mg. Rommel Plasencia Soto. Al Dr. Alberto Bueno Mendoza, por la constante asesoría. Al Dr. Alfredo Altamirano Enciso, por haber realizado el análisis del material óseo humano y animal.

\section{XII.- Bibliografía}

ARRIAGA, Pablo José

1968 Extirpación de la idolatría en el Perú. Biblioteca de autores españoles. Tomo 209. Madrid, 239 pp.

CÁCEDA GUILLÉN, Daniel

2014 Cerro Mango Cápac: Un apu Atavillos en la cuenca alta del río Chancay. Arqueología de las cuencas alto y medio andinas del departamento de Lima. Pieter van Dalen, editor. Lima, pp. 321326.

CELESTINO, Olinda

1998 Transformaciones religiosas en los Andes Peruanos. Gazeta de Antropología. № 14. Madrid, 22 pp. Edición electrónica.

DOYLE, Mary E.

1988 The Ancestros Cult and Burial Ritual in Seventennth and Eightennth Century Central Peru. Dissertation for the degree Doctor of Philosophy. Universidad de California. Los Ángeles.

DUVIOLS, Pierre

1967 Un inédit de Cristobal de Albornoz: la instrucción para descubrir todas las guacas del Piru y sus camayos y haziendas. Journal de la Societé des américanistes, № 56 (1). París, pp. 7-39.

1986 Cultura andina y represión. Procesos y visitas de idolatrías y hechicerías en Cajatambo, Siglo XVII. Centro de Estudios Rurales Andinos Bartolomé de Las Casas. Cusco. 568 Pgs.

ESTENSSORO FUCHS, Juan Carlos

2003 Del paganismo a la santidad: La incorporación de los indios del Perú al Catolicismo. PUCP. 366 pp.

GALDAMES, Luis y MARSILLI, María

2012 Culto a los ancestros, hechiceros y resistencia colonial: El caso de Gregorio Taco, Arequipa, 1750. Universidad de Tarapacá y John Carrol University. Arica, 588 pp.

GAREIS, Iris

2007 Extirpación de idolatrías e identidad cultural en las sociedades andinas del Perú virreinal (Siglo XVII). http://nuevomundo.revues.org/index3346

GUFFROY, Jean

2011 Las tradiciones centro-andinas de rocas grabadas (Perú): evoluciones y continuidades. Chungara. Revista de Antropología Chilena, Volumen 43, $\mathrm{N}^{\circ} 1$. 
HERNÁNDEZ ASTETE, Francisco

2012 Los Incas y el poder de sus ancestros. Fondo Editorial Pontificia Universidad Católica del Perú. Lima, $292 \mathrm{pp}$.

HUERTAS VALLEJOS, Lorenzo

1981 La religión en una sociedad rural andina, Siglo XVII. Universidad Nacional San Cristóbal de Huamanga. $158 \mathrm{pp}$.

2008 Los oráculos en la historia andina. Editorial Universitaria. Universidad Ricardo Palma. Lima, $54 \mathrm{pp}$.

IBARRA ASENCIOS, Bebel

2008 Ancestros y muerte durante la época prehispánica en la Sierra de Ancash: buscando nuestros antepasados. La complejidad social en la sierra de Ancash. Trabajos de la primera y segunda mesa redonda de Arqueología de la sierra de Ancash. Alexander Herrera, Carolina Orsini y Kevin Lane, editores. Civiche Raccolte d'Arte Applicata del Castello Sforzesco - Raccolte Extraeuropee y PUNKU Centro de Investigación Andina. Milan, pp. 85-100.

\section{LAZO PINTO, Roxana}

2012 Costumbres y tradiciones en cementerios de Lima el 1 de noviembre en tiempos de globalización. Investigaciones Sociales. № 29. Instituto de Investigaciones Histórico Sociales. Facultad de Ciencias Sociales. Universidad Nacional Mayor de San Marcos. Lima, pp. 189-198.

QUEREJAZU LEWIS, Roy

1998 Tradiciones de cúpulas en el departamento de Cochabamba. SIARB, Boletín Nº 12.

SUAREZ MUCHA, Hipólito

2014 Introducción al estudio de la cultura Los Atavillos. Revista Cultural del Colegio Los Atavillos, № 1. La Perla, pp. 13-50.

TAYLOR, Gerald

1987 Ritos y tradiciones de Huarochirí del Siglo XVII. Instituto de Estudios Peruanos. Lima, 615 pp.

VAN DALEN LUNA, Pieter

2007 Reconocimiento arqueológico en la cuenca alta del río Chancay-Huaral: Margen izquierda (distritos de Atavillos Alto, Santa Cruz de Andamarca y Pacaraos). Nuevos datos para comprender los procesos socio culturales Atavillos. Kullpi. Investigaciones culturales en la provincia de Huaral y el Norte Chico. № 3. Huaral, pp. 57-148.

2014 Apuntes para el estudio de la Arqueología e Historia de la comunidad campesina de San José de Baños, distrito de Atavillos Alto, provincia de Huaral. Ed. Gutemberg. 2014. Lima, 212 pp.

VAN DE GUCHTE, Maarten

1990 "Carving de world": Inca monumental sculpture and landscape. Tesis de Doctorado. University of Illinois at Urbana - Champaing. Ann Arbor.

VILLAR CORDOVA, Pedro

1982(1935) Arqueología del departamento de Lima. Ed. Atusparia, 2º edic. Lima. 